\title{
RESPOSTAS DE CINCO GRAMÍNEAS FORRAGEIRAS A NÍVEIS DE CALCÁRIO EM UM LATOSSOLO VERMELHO-ESCURO
}

\author{
FRANCISCO JOSÉ MITIDIERI \\ Engenheiro Agrônomo
}

Orientador: Dr. HERBERT BARBOSA DE MATTOS

Dissertação apresentada à Escola Superior de Agricultura "Luiz de Queiroz", da Universidade de São Paulo, para obtenção do título de Mestre em Agronomia, Área de Concentração: Ciência Animal e Pastagens.

PIRACICABA

Estado de São Paulo - Brasil

Fevereiro - 1995 
CATALOGACAO NA FULLICARAR

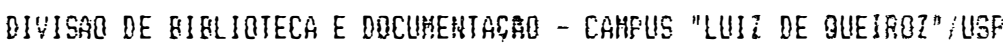

Mitidieri. Francieco Jose

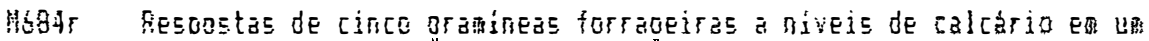
latuseslo verselto-escuro. Firacicata, 1995.

13ik. ilue.

Disc.iMestrel - ESALQ

Bibligoratia.

1. Gologerno

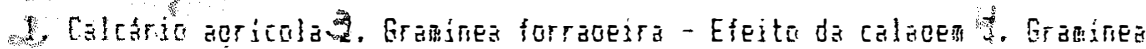
forraneira - Wutriczo Solo de cerrado - Acidez J. Escula Sugeriar de foricul tura luiz de Queiraz. Firaricata 


\title{
RESPOSTAS DE CINCO GRAMÍNEAS FORRAGEIRAS \\ A NÍVEIS DE CALCÁRIO EM UM LATOSSOLO VERMELHO-ESCURO
}

\author{
FRANCISCO JOSÉ MITIDIERI
}

Aprovada em: 10.04.1995

Comissão Julgadora:

Dr. HERBERT BARBOSA DE MATTOS

Prof. Dr. FRANCISCO ANTONIO MONTEIRO

Dr. JOSÉ ALFREDO USBERTI FILHO

I.Z./N.ODESSA ESALQ/USP

IAC/Campinas 
Aos meus pais

EDENA e JOSÉ

e minha esposa

MIRIAM

pela dedicação, apoio e incentivo.

OFEREÇO. 


\section{AGRADECIMENTOS}

Ao pesquisador científico Dr. Herbert Barbosa de Mattos pela orientação dedicada para a realização deste trabalho.

Aos pesquisadores científicos Dr. Joaquim Carlos Werner e Dr. Valdinei José Paulino pelo acompanhamento na fase experimental.

À pesquisadora científica Maria Tereza Colozza pela orientação nas análises químicas de material vegetal.

Ao Departamento de Química da EALQ/USP e ao técnico de laboratório Fernando Éder Ré e equipe pela realização das análises químicas de solo.

Aos Instituto de Zootecnia de Nova Odessa pela cessão de suas instalações e aos funcionários da casa de vegetação, Maria Alice Crestani, Flávio Rubens de Jesus e Antonio Marco Pigato pelo auxílio na condução da fase experimental.

À minha esposa Miriam V.M. Meloni Mitidieri pelo auxílio nas análises estatísticas e revisão do texto.

Ao Departamento de Zootecnia da ESALQ/USP pela oportunidade de realização do curso de pós-graduação em Ciência Animal e Pastagens.

Aos órgãos CAPES e FAPESP pelo auxílio financeiro. 


\section{ÍNDICE}

Página

RESUMO

vii

SUMMARY

$\mathbf{X}$

1. INTRODUÇÃO

2. REVISÃO DE LITERATURA . . . . . . . . . . . . . . . . 3

2.1. Os solos de cerrado . . . . . . . . . . . . . . . . . . . 3

2.1.1. Características físicas e químicas . . . . . . . . . . . . . . 4

2.2. O processo de acidificação do solo . . . . . . . . . . . . . . . . . 5

2.3. O calcário como corretivo do solo . . . . . . . . . . . . . . . . . . . 6

2.4. Descrição das espécies utilizadas . . . . . . . . . . . . . . . . 7

2.5. Comportamento de gramíneas em relação à saturação por alumínio, à solos ácidos e respostas à calagem . . . . . . . . . . . . . 13

2.5.1. Comportamento do capim Andropogon gayanus . . . . . . 15

2.5.2. Comportamento dos capins Brachiaria decumbens, B. humidicola e B. brizantha cv. Marandu . . . . . . . . . . . . . 17

2.5.3. Comportamento de Panicum maximum . . . . . . . . . . . 19

2.6. Efeitos da calagem nos níveis de nutrientes nas forrageiras tropicais . . 23

3. MATERIAL E MÉTODOS _. . . . . . . . . . . . . 27

3.1. Coleta e preparo do solo . . . . . . . . . . . . . . . . . 27

3.2. Incubação do solo com óxidos . . . . . . . . . . . . . . . . . . . . 28

3.3. Espécies estudadas . . . . . . . . . . . . . . . . . . . . 30

3.4. Delineamento experimental . . . . . . . . . . . . . . . . 31

3.5. Semeadura, adubações e condução do experimento em vasos . . . . 32

3.6. Análises químicas da parte aérea e raiz . . . . . . . . . . . . . 35

3.7. Análises químicas do solo . . . . . . . . . . . . . . . . 36 
Página

4. RESULTADOS E DiSCUSSÃO . . . . . . . . . . . . . . . . 37

4.1. Solo . . . . . . . . . . . . . . . . . . . . . . . 37

4.2. Planta . . . . . . . . . . . . . . . . . . . . 48

4.2.1. Produção de matéria seca - parte aérea e total . . . . . . . 48

4.2.2. Peso seco de raiz . . . . . . . . . . . . . . . . . . 53

4.2.3. Número médio de perfilhos/vaso . . . . . . . . . . . 55

4.2.4. Altura da haste principal . . . . . . . . . . . . . . . . 56

4.2.5. Composição mineral - macronutrientes . . . . . . . . . . 58

4.2.5.1. Nitrogênio . . . . . . . . . . . . . . . . 58

4.2.5.2. Quantidade total de nitrogênio na parte aérea (QTN) . . 59

4.2.5.3. Nitrogênio nas raízes . . . . . . . . . . . . 64

4.2.5.4. Fósforo . . . . . . . . . . . . . 67

4.2.5.5. Potássio . . . . . . . . . . . . . . . . . 69

4.2.5.6. Cálcio e magnésio . . . . . . . . . . . . . . . 70

4.2.5.7. Enxofre . . . . . . . . . . . . . . . . . 84

4.2.6. Composição mineral - micronutrientes . . . . . . . . . 89

4.2.6.1. Boro . . . . . . . . . . . . . . . . . . 89

4.2.6.2. Cobre . . . . . . . . . . . . . . . . . . 94

4.2.6.3. Ferro . . . . . . . . . . . . . . 99

4.2.6.4. Manganês . . . . . . . . . . . . . . . 100

4.2.6.5. Zinco . . . . . . . . . . . . . . . . . . 105

5. CONCLUSÕES . . . . . . . . . . . . . . . . . . . . . 111

REFERÊNCIAS BIBLIOGRÁFICAS . . . . . . . . . . . . . . 113

APÊNDICE . . . . . . . . . . . . . . . . . . . . . 125 


\title{
RESPOSTAS DE CINCO GRAMÚNEAS FORRAGEIRAS À NÍVEIS DE CALCÁRIO EM UM LATOSSOLO VERMELHO ESCURO
}

\author{
Autor: Francisco José Mîtidieri \\ rientador: Dr. Herbert Barbosa de Mattos
}

\section{RESUMO}

Com uma área de aproximadamente 180 milhões de hectares, o cerrado brasileiro representa grande potencial para a expansão da pecuária.

A avaliação do comportamento de novos cultivares de gramíneas forrageiras adaptadas à condição do "complexo - cerrado" torna-se importante ferramenta no auxílio à ocupação racional e econômica pela pecuária naquela região.

No presente trabalho avaliou-se o comportamento dos dois novos cultivares Panicum maximum cv. Vencedor e $P$. maximum cv. Centenário recomendados para terras ácidas e os cultivares $P$. maximum Jacq. (Colonião cv. IZ-1), Brachiaria brizantha (Hoechst ex. A. Rich) Stapf cv. Marandu e Andropogon gayanus (Hochst) Hack var. bisquamulatus cv. Planaltina. Estas gramíneas foram submetidas à níveis de calcário, cultivadas em solo com características físicas e químicas de solo sob vegetação de cerrado em casa de vegetação em Nova Odessa, no período de outubro de 1990 a março de 1991. 
, 
Verificou-se que a elevação dos níveis de calcário proporcionou aumentos no $\mathrm{pH}$, nos teores de $\mathrm{P}, \mathrm{Ca}^{2+}, \mathrm{Mg}^{2+}$, na soma de bases (S) e saturacão por bases ( $\mathrm{V} \%)$ e na diminuição nos teores de $\mathrm{K}^{+}$, acidez potencial $(\mathrm{H}+\mathrm{Al})$ e alumínio trocável $\left(\mathrm{Al}^{3+}\right)$ no solo, 40 dias após a calagem.

Os cultivares Colonião IZ-1, Vencedor, Centenário, Marandu e Andropogon apresentaram comportamentos diferentes entre si, quando considerados os diversos parâmetros analisados, porém não aumentaram a produção de matéria seca com o aumento dos níveis de calcário, não se recomendando portanto o uso deste corretivo quando a saturação por bases deste solo estiver em $30 \%$ ou acima. No $1^{\circ}$. corte houve efeito negativo da aplicação de calcário na produção de matéria seca dos cultivares Colonião IZ-1, Vencedor, Centenário e Marandu a partir de 57,03\% de saturação por bases.

Com relação à produção de matéria seca os novos cultivares forrageiros Vencedor e Centenário se comportaram igualmente aos demais cultivares avaliados no trabalho.

A elevação dos níveis de calcário proporcionou aumentos reais nos teores de $\mathrm{Ca}$ e $\mathrm{Mg}$ no $1^{\circ}$. e $2^{\circ}$. corte, de $\mathrm{K}$ e de $\mathrm{B}$ no $2^{\circ}$. corte, do teor de Fe no $1^{\circ}$. corte; e diminuição real na percentagem de $\mathrm{P}$ no $1^{\circ}$. corte, de $\mathrm{Zn}$ no $2^{\circ}$. corte e de $\mathrm{Mn}$ em ambos os cortes na matéria seca da parte aérea dos cultivares IZ-1, Vencedor, Centenário e Marandu.

Não houve efeito significativo da aplicação de calcário nos teores de $\mathrm{N}, \mathrm{P}, \mathrm{K}, \mathrm{Ca}, \mathrm{Mg}$, teores de $\mathrm{B}, \mathrm{Cu}, \mathrm{Fe}$ e $\mathrm{Zn}$ na matéria seca da parte aérea do capimandropogon no $1^{\circ}$. e $2^{\circ}$. corte e de $\mathrm{Mn}$ no $1^{\circ}$. corte. $\mathrm{O}$ teor de Mn na matéria seca do $2^{\circ}$. corte diminuiu com a elevação dos níveis de calcário. 
No $1^{\circ}$. corte, os novos cultivares Vencedor e Centenário apresentaram maiores teores de $\mathrm{K}$ na matéria seca da parte aérea que os cultivares Colonião IZ-1 e Marandu, independente do nivel de calcário empregado, e maior percentagem de S nos níveis mais elevados de calcário.

O cultivar Vencedor apresentou maior percentagem de Ca na matéria seca da parte aérea desde o nível 1 (ausência de calcário) até o último nível aplicado do corretivo no $1^{\circ}$. corte e até o nível 2 no $2^{\circ}$. corte. 


\title{
RESPONSES OF FIVE FORAGE SPECIES TO LIMING LEVELS IN A DARK-RED OXISOL
}

\author{
Author: Francisco José Mitidieri \\ Adviser: Dr. Herbert Barbosa de Mattos
}

SUMMARY

With an area around 180 million hectars, the Brazilian savannah represents a huge potential of modern livestock farms.

The evaluation of new acid-soils adapted varieties of grasses plays an important role and it is a tool to provide the racional and economical occupation of that area.

This experiment has evaluated the performance of two new varieties Panicum maximum cv. Vencedor and P. maximum cv. Centenario, recommenDed to acid soils, and the varieties P. maximum Jacq. cv. IZ-1 Brachiaria brizantha (Hochst ex A. Rich) Stapf cv. Marandu and Andropogon gayanus (Hochst) Hack var. bisquamulatus cv. Planaltina.

The grasses were grown in lime levels in an Oxisol with savannah characteristics in glass-house, Nova Odessa, from October, 1990 to March, 1991. 
The increase in lime levels provided increases on soil $\mathrm{pH} ; \mathrm{P}, \mathrm{Ca}^{2+}$ and $\mathrm{Mg}^{2+}$; exchangeable bases (S) and percent bases saturation (V\%). On the other hand, they provided decrease on $\mathrm{K}^{+}$, potential acidity $(\mathrm{H}+\mathrm{Al})$ and on exchangeable $\mathrm{Al}\left(\mathrm{Al}^{3+}\right)$, at 40 days after soil liming.

The tropical grasses IZ-1, Vencedor, Centenario, Marandu and Andropogon presented different behavior when considered all the parameters analysed, although the dry-matter yield did not increase with the increase of lime. In fact, on the first cut there has been a liming depressive effect on dry-matter yield of IZ-1, Vencedor, Centenario and Marandu, when bases saturation reached $57.03 \%$.

Liming has provided increases on $\mathrm{Ca}$ and $\mathrm{Mg}$ percentage on $1^{\text {st }}$ and $2^{\text {nd }}$ cut (except for $\mathrm{Ca}$, in Marandu), on $\mathrm{K}$ percentage and $\mathrm{B}$ on $2^{\text {nd }}$ cut, Fe on $1^{\text {st }}$ cut; and decrease on $\mathrm{P}$ percentage on $1^{\text {st }}$ cut; on $\mathrm{Zn}$ on $2^{\text {nd }}$ cut and $\mathrm{Mn}$ on both cuts of IZ-1, Vencedor, Centenario and Marandu shoot dry-matter.

It has not been found effect on $\mathrm{N}, \mathrm{P}, \mathrm{K}, \mathrm{Ca}, \mathrm{Mg}$ percentages, on $\mathrm{B}$, $\mathrm{Cu}, \mathrm{Fe}$ and $\mathrm{Zn}$ on $1^{\text {st }}$ and $2^{\text {nd }}$ cut, and $\mathrm{Mn}$ on $1^{\text {st }}$ cut of Andropogon shoot dry matter. Manganese of shoot dry-matter decreased with the liming increase in the $2^{\text {nd }}$ cut.

In the $1^{\text {st }}$ cut, the new varieties Vencedor and Centenario showed higher K percentage on shoot dry matter than IZ-1 and Marandu, no matter the liming level used, and higher S percentage in the higher levels. Vencedor showed the highest $\mathrm{Ca}$ percentage on shoot dry-matter since the $1^{\text {st }}$ level (no liming) to the last liming level in the $1^{\text {st }}$ cut, and to the $2^{\text {nd }}$ level in the $2^{\text {nd }}$ cut. 
The experiment showed no liming need when the soil bases saturation percentage is $30 \%$ or higher. Considering the dry-matter yield, the new grasses Vencedor and Centenario had the same liming response when compared to the other grasses evaluated in this trial. 


\section{INTRODUÇÃO}

O Brasil, devido à grande extensão territorial, abrange as regiões Equatorial, Tropical e Sub-tropical.

Com uma área de aproximadamente 180 milhões de hectares, o cerrado brasileiro apresenta grande potencial econômico, sendo considerado uma importante alternativa para a expansão da pecuária.

Entretanto, o "complexo-cerrado", como é conhecido, ainda possui desafios e limitações técnicas a serem superados quando se consideram as interações climasolo-planta.

A avaliação do comportamento de espécies de plantas forrageiras mais adaptadas àquela condição edafoclimática assume papel fundamental na ocupação racional e econômica da região, tornando-se importante ferramenta de trabalho para técnicos e produtores rurais.

Recentemente, a pesquisa oficial tem realizado trabalhos no sentido de lançar no mercado novos cultivares de gramíneas forrageiras, ampliando as opções para a formação de pastagens melhoradas. 
Neste contexto, técnicos e pecuaristas deparam-se com dúvidas tais como qual a espécie a ser utilizada em solos problemáticos, uma vez que existem atualmente cultivares oriundos de regiões de clima tropical e solos ácidos, a respeito dos quais pouco se conhece sobre o comportamento em relação à cultivares já utilizados, ou decidindo-se pela correção do solo através da calagem, como seria o comportamento dos cultivares quanto à produção e teores de macro e micro nutrientes.

O objetivo do presente trabalho foi o de estudar cinco gramíneas forrageiras tropicais: Andropogon gayanus (Hochst) Hack var. bisquamulatus cv. Planaltina, Brachiaria brizantha (Hochst ex. A. Rich) Stapf. cv. Marandu, Panicum maximum Jacq. (Colonião) cv. IZ-1, P. maximum cv. Centenário e $P$. maximum cv. Vencedor (sendo os dois últimos cultivares recém-lançados e recomendados para terras ácidas), cultivados em casa de vegetação, em solo com características de solo de cerrado, submetendo à níveis de calcário.

Foram ainda estudadas a concentração de nutrientes na parte aérea, nitrogênio no sistema radicular das gramíneas e os teores de nutrientes e alumínio no solo nos níveis de correção utilizados. 


\section{REVISÃO DE LITERATURA}

\subsection{Os Solos de Cerrado}

A região dos cerrados, com aproximadamente 180 milhões de hectares, representa a mais viável e econômica alternativa para a expansão da pecuária brasileira (EMBRAPA, 1985b). Deste total, 73\% se encontram distribuídos nos Estados de Goiás, Tocantins, Mato Grosso, Mato Grosso do Sul e Minas Gerais (KORNELIUS et al., 1979). Técnicos e pecuaristas têm realizado grandes esforços para sua colonização racional, a fim de torná-lo mais produtivo.

Entretanto, existem inúmeras dificuldades a serem superadas, tanto que no final da década de 1970 Azevedo e colaboradores ${ }^{1}$, citados por AZEVEDO \& CAZER (1982), afirmaram que "embora a região dos cerrados se constitua na

\footnotetext{
${ }^{1}$ AZEVEDO, D.G. et al. Desconhecimento dos Recursos Naturais e Sócio-Econômicos da
} Área dos Cerrados. In: Pesquisa na região dos cerrados. Planaltina, Centro de Pesquisas na região dos cerrados, 1978. (mimeografado). 
mais válida e atual opção para a ampliação da fronteira agrícola do País, é verdade também que seu aproveitamento ainda é dependente de um melhor conhecimento do seu potencial através do levantamento e avaliação de seus recursos naturais e sócio-econômicos".

\subsubsection{Características físicas e químicas}

Os solos mais representativos da área dos cerrados são os Latossolos Vermelho-Escuros (LE) e os Latossolos Vermelho-Amarelos (LV), que abrangem cerca de $52 \%$ da área. Apresentam o perfil bastante profundo, podendo-se encontrar dentro de uma mesma unidade solos com características químicas e físicas diversas (THOMAS et al., 1981). Já as Areias Quartzosas ocupam em torno de $20 \%$ da área, com fertilidade natural muito baixa (KORNELIUS et al., 1979).

Goodland $^{2}$, citado por MARTINEZ et al. (1984), mostrou a sequência de intemperismo dos minerais de argila presentes nestes solos. $\mathrm{O} \mathrm{SiO}_{2}$ e $\mathrm{Al}_{2} \mathrm{O}_{3}$ dão origem a caulinita $(\mathrm{Si}: \mathrm{Al})$, e posteriormente à gibsita $(\mathrm{Al})$, com o $\mathrm{Fe}_{2} \mathrm{O}_{3}$ dando origem à hematita $(\mathrm{Fe})$.

Em termos médios, os percentuais dos principais constituintes da fração argila são $33,8 \%, 23,4 \%$ e $9,1 \%$ para caulinita, gibsita e $\mathrm{Fe}_{2} \mathrm{O}_{3}$ livre, respectivamente. Através de estudos de correlação foi detectado que quanto maior a percentagem de gibsita, menor é a capacidade de troca de cations (CTC) da fração argila (LOPES, 1984).

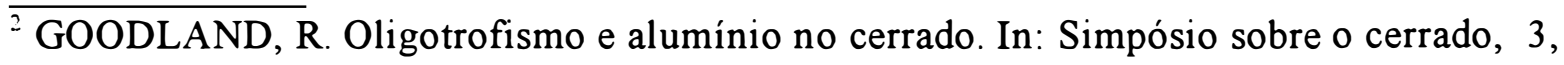
São Paulo, Editora Edgar Blucher Ltda. 1971. p.44-60. 
Possuindo baixa reserva de minerais intemperizáveis, esses solos apresentam acidez elevada, baixa CTC, alta capacidade de fixação de fósforo, alta saturação por alumínio e deficiência quase generalizada de macro e micronutrientes (MENDES, 1972; GALRÃO \& LOPES, 1982; LOPES, 1984 e MARTINEZ et al., 1984).

Estas, entre outras características, estão presentes em cerca de $80 \%$ dos solos de cerrado e baixam consideravelmente a capacidade de suporte das pastagens, atingindo níveis de ocupação de uma unidade animal para cada 5 hectares (MOURTHÉ, 1972; THOMAS et al., 1981).

\subsection{0 processo de acidificação do solo}

A acidificação do solo pode ser visualizada como um processo contínuo, onde diversas causas contribuem para a mesma. Pode derivar-se da reação da água com a matéria orgânica, dando origem a ácidos orgânicos; da reação da água com o $\mathrm{CO}_{2}$, formando ácido carbônico; da reação da água com compostos nitrogenados, resultando em ácido nítrico; da formação de ácido sulfúrico, pela oxidação do enxofre por bactérias, ou ainda do hidrogênio resultante do metabolismo vegetal excretado diretamente na rizosfera. Quando a atividade do hidrogênio torna-se suficientemente elevada $(\mathrm{pH}<6)$ as argilas silicatadas são solubilizadas e o alumínio é liberado para a solução do solo (COLEMAN \& THOMAS, 1967).

Em solução, o alumínio ocorre na forma hidratada $\mathrm{Al}\left(\mathrm{H}_{2} \mathrm{O}\right)_{6}{ }^{3+}$. Entretanto, a atração do Al pelo oxigênio da molécula de água é tão forte que tende a 
repelir $\mathrm{o}^{+}$ou próton da molécula de água, aumentando a concentração de $\mathrm{H}^{+}$na solução. Este processo é chamado de hidrólise e pode resultar em reação ácida também com sais de $\mathrm{Mn}^{-2}, \mathrm{Fe}^{-2}$ e $\mathrm{Fe}^{+3}$

\subsection{O calcánio como cometivo do solo}

A prática da calagem (incorporação do corretivo calcário ao solo em doses adequadas), tem sido recomendada e utilizada com bastante sucesso para a correção da acidez, diminuição da toxicidade do alumínio, ferro e manganês, promover a adição dos macronutrientes cálcio e magnésio (MIRANDA et ali., 1982; MARTINEZ et al., 1984;

SOUZA et al., 1985) e adição de micronutrientes (ALCARDE, 1986), aumentar a disponibilidade de molibdênio, a atividade microbiana e a liberação de nutrientes tais como nitrogênio, fósforo e enxofre pela decomposição da matéria orgânica e ainda aumentar as cargas dependentes de $\mathrm{pH}$ e consequentemente a capacidade de troca de cátions (PEARSON \& HOVELAND, 1974; LOPES, 1984).

Os produtos considerados como corretivos mais comuns da acidez dos solos são o próprio calcário (rocha moída) cujos "materiais neutralizantes" são o carbonato de cálcio $-\mathrm{CaCO}_{3}$ e o carbonato de magnésio $-\mathrm{MgCO}_{3}$, a cal virgem, cujos constituintes neutralizantes são o óxido de cálcio - $\mathrm{CaO}$ e o óxido de magnésio - $\mathrm{MgO}$ e a cal hidratada ou extinta - $\mathrm{Ca}(\mathrm{OH})_{2}$, escória de siderurgia - sub-produto da indústria do ferro e do aço e calcários marinhos (ALCARDE, 1986). 
Dentre os critérios para a avaliação de doses de calcário a ser aplicada está o método da saturação por bases - V\%, que em 1983 passou a ser recomendado pelo Instituto Agronômico de Campinas. O método baseia-se na correlação positiva entre a saturação por bases $\left(\mathrm{Ca}^{2+}, \mathrm{Mg}^{2+}, \mathrm{K}^{+}\right.$e em alguns casos o $\left.\mathrm{Na}^{+}\right)$e o $\mathrm{pH}$, correlação esta mais estreita quando o pH é medido em solução de $\mathrm{CaCl}_{2} \quad 0,01 \mathrm{~N}$. Tal método leva em consideração ainda a $\mathrm{CTC}=\mathrm{t}+\left[\mathrm{Ca}^{2+}+\mathrm{mg}^{2+}+\mathrm{K}^{+}+(\mathrm{H}+\mathrm{Al})\right]$ sendo o último termo definido por acidez potencial (QUAGGIO, 1983; LOPES, 1984; RAIJ, 1988).

\subsection{Descrição das espécies utilizadas}

Nos últimos anos, com a degradação da fertilidade natural dos solos e a expansão da fronteira agropecuária em direção ao Brasil Central, novas espécies foram introduzidas e liberadas para plantio por órgãos públicos e privados de pesquisa, com o intuito de oferecer ao pecuarista espécies mais adaptadas àquela condição edafoclimática.

\section{Andropogon gayanus Kunt. var. bisquamulatus (Hochst) Hack cv. Planaltina}

Proveniente de Shika, Nigéria, foi trazido para o Centro Internacional de Agricultura Tropical - CIAT - Colômbia, em 1973 recebendo a denominação de CIAT 621. Foi posteriormente introduzido no Brasil recebendo no Centro de Pesquisa 
Agropecuária dos Cerrados - CPAC, o número de introdução CPAC - 3082. Em 1980, esta introdução foi indicada para a região dos cerrados recebendo o nome de capim Andropogon, cultivar Planaltina.

Gramínea perene, cespitosa, alcançando até 2 metros ou mais de altura, folhas abundantes, macias, coloração prata-esverdeada, aparência aveludada devido a micropilosidade e possuindo um estreitamento na base, o que lhe confere aspecto de falso peciolo (ALCÂNTARA \& BUFARAH, 1979; MITIDIERI, 1988).

O seu sistema radicular é denso e profundo, explorando grande volume de solo, justificando sua boa tolerância à seca e a habilidade em retirar minerais de solos pobres. O cultivar apresenta excelente tolerância a baixo $\mathrm{pH}$ e alta saturação por $\mathrm{Al}^{---}$(THOMAS et al., 1981; GOEDERT et al., 1985).

\section{Brachiaria brizantha cv. Marandu}

O nome Marandu (que significa novidade no idioma guarani) foi dado a um ecótipo de Brachiaria brizantha que foi selecionado, estudado e liberado pelo Centro Nacional de Pesquisa de Gado de Corte (CNPGC) em conjunto com o Centro de Pesquisa Agropecuária dos Cerrados (CPAC) em 1983-1984.

Pertencente ao gênero Brachiaria, classificada como Brachiaria brizantha (Hochst ex A. Rich) Stapf. cv. Marandu, esta gramínea é originária de uma região vulcânica da África, onde os solos geralmente apresentam bons níveis de fertilidade, com a precipitação pluviométrica anual ao redor de $700 \mathrm{~mm}$ e cerca de 8 meses de seca no inverno (EMBRAPA, 1985a). 
Planta cespitosa, muito robusta, de 1,5 a $2,5 \mathrm{~m}$ de altura, apresenta colmos iniciais prostrados, mas produz perfilhos predominantemente eretos. Rizomas muito curtos e encurvados, bainhas pilosas com ćílios nas margens, geralmente mais longas que os entre-nós, escondendo os nós, o que confere a impressão de haver densa pilosidade nos colmos vegetativos.

O cultivar Marandu pode ser diferenciado de outros ecótipos de $B$. brizantha pela associação obrigatória das seguintes características: plantas sempre robustas e com intenso afilhamento nos nós superiores dos perfilhos reprodutivos; presença de pêlos na porção apical dos entre-nós, bainhas pilosas, lâminas largas e longas com pubescência apenas na face inferior, e com margens não cortantes, raque sem pigmentação arroxeada e espiguetas ciliadas no ápoice (Valls \& Sendultry $^{3}$, citados por EMBRAPA, 1985a; MITIDIERI, 1988).

Os ensaios de avaliação conduzidos pelo CNPGC-EMBRAPA revelaram a adaptação deste cultivar à região dos cerrados, com alta produção de forragem, persistência e boa capacidade de rebrota, tolerância ao frio, à seca e ao fogo. Responde muito bem à adubação fosfatada apresentando entretanto, boa tolerância a altos níveis de alumínio e manganês no solo. É indicada também como uma excelente alternativa em locais de alta incidência de "cigarrinha das pastagens" (GHISI \& PEDREIRA, 1987).

\footnotetext{
${ }^{3}$ VALLS, J.F.M. \& SENDULSKY, T. Descrição botânica. In: VALLS, J.F.M. Carta, 6 de julho de 1984. Brasília, para Saladino G. Nunes. Campo Grande, MS, p. 4-6.
} 


\section{Panicum maximum Jacq. Colonião - IZ-1}

O capim colonião, P. maximum Jacq., é originário da Costa Oeste da África e foi trazido para Barbados e Brasil nos séculos XVII e XVIII, respectivamente, em navio de escravos. Via de regra, está concentrado na África, Américas Central e do Sul, Nordeste da Austrália, Índia, Sudoeste da Ásia e ilhas do Pacífico (Motta ${ }^{4}$, citado por McCOSKER \& TEITZEL, 1975).

Planta perene, com rizomas grossos, colmos eretos atingido até $4 \mathrm{~m}$ de altura, possui, em geral, 6 nós pilosos e expostos. Folhas verdes claras, normalmente com comprimento de $100 \mathrm{~cm}$ por 1 a $3,5 \mathrm{~cm}$ de largura; nervuras verde-escuras, lâmina fortemente quilhada com até 7 subnervuras sub-principais, brancas, colocadas de cada lado da nervura principal acuminada e com margens serreadas e levemente pilosas (OLIVEIRA \& ALCÂNTARA, 1978; ALCÂNTARA \& BUFARAH, 1979).

É uma das principais gramíneas forrageiras da América tropical, agressiva, com boa resistência ao pisoteio e ao fogo e tida como exigente em fertilidade do solo. Prefere terras profundas, friáveis, levemente arenosas, vegetando bem em locais quentes, onde a precipitação está acima de $900 \mathrm{~mm}$ anuais (ALCÂNTARA \& BUFARAH, 1979; MITIDIERI, 1988).

\footnotetext{
${ }^{4}$ MOTTA, M.S. Panicum maximum. Empire Journal of Experimental Agriculture. 21:
} 33-41. 1953. 


\section{Panicum maximum cv. IAC Centenánio}

Segundo USBERTI FILHO (1988), o P. maximum IAC Centenário é um híbrido $\mathrm{F}_{1}$ apomítico, derivado do cruzamento artificial do cv. Angola com a linhagem sexual 28, realizado em 1978. O cultivar Angola, originário da África do Sul foi introduzido no Brasil em 1973 enquanto a linhagem sexual 28 foi selecionada através de eletroforese e testes de progênies, a partir da introdução PI 277933 no Instituto Agronômico de Campinas.

A planta do IAC - Centenário, quando adulta, apresenta folhas de largura média $(2,5$ a $3,0 \mathrm{~cm})$ e compridas $(70 \mathrm{a} 80 \mathrm{~cm})$ e coloração verde escura, com pouca ou nenhuma pilosidade. As bainhas e lígulas, entretanto, são densamente pilosas com variação de intensidade de acordo com a idade da planta.

A altura média da planta, na época do florescimento, varia de 1,80 a 2,20 m enquanto o hábito de crescimento pode ser classificado como semi-ereto. O ciclo normal de florescimento (número de dias da germinação das sementes até $50 \%$ das panículas florescidas) é de 140 a 150 dias e o ciclo de maturação de sementes de 170 a 180 dias.

Quanto à tolerância a estresses ambientais, o cultivar IAC Centenário mostrou-se altamente tolerante ao alumínio, tanto em testes de laboratório como em experimentos de campo. 


\section{Panicum maximum cv. Vencedor}

O capim P. maximum cv. Vencedor foi lançado pelo Centro de Pesquisa Agropecuária dos Cerrados - CPAC - EMBRAPA em 1990, como nova opção de graminea para formação de pastagens na região dos cerrados.

É resultante de trabalhos de cruzamento e seleção, desenvolvidos inicialmente no Centro Internacional de Agricultura Tropical - CIAT, Colômbia, em 1979. Foi cruzada a linhagem TIFT-49, que apresentava sexualidade e auto-incompatibilidade com os oito melhores acessos de Panicum disponíveis no CIAT. As 6 melhores linhagens obtidas, em condições de estresse ( $\mathrm{pH} 4,7$ e alta sautração por $\mathrm{Al}^{3+}$ ) foram transferidas para o CPAC, onde se iniciaram as etapas de avaliação. O acesso registrado sob o número BRA 008826 se destacou e após 4 anos de avaliação foi lançado com o nome de cultivar Vencedor (EMBRAPA, 1990).

O capim Vencedor é uma gramínea cespitosa que atinge até $1,60 \mathrm{~m}$ de altura. Possui folhas com $1,9 \mathrm{~cm}$ de largura, coloração verde-clara, sem cerosidade e pilosidade. A inflorescência assemelha-se a do colonião comum. É adaptada a solos de média a alta fertilidade, porém praticamente não responde à aplicação de calcário, onde o solo apresenta saturação por bases de 30\% (EMBRAPA, 1990). 


\subsection{Comportamento de gramíneas em relação à saturação por alumínio, à solos ácidos e respostas à calagem}

A exata natureza bioquímica da toxicidade por Al é ainda debatida. Propriedades morfológicas, fisiológicas e bioquímicas tem sido associadas a diferenças na tolerância a toxicidade por Al. Entre elas, FOY (1974), apontou a habilidade diferencial de espécies e cultivares em alterar o $\mathrm{pH}$ de suas rizosferas. $\mathrm{O}$ autor citou trabalhos de sua autoria e colaboradores onde variedades de trigo 'Monon' e cevada 'Kearney' sensíveis a Al induziram um menor valor de $\mathrm{pH}$ no meio de crescimento quando comparados com as variedades tolerantes a Al de trigo 'Atlas 66' e de cevada 'Dayton'. Devido ao abaixamento do $\mathrm{pH}$ induzido pelas plantas na zona radicular aumentou-se a solubilidade e o potencial de toxicidade do Al. Segundo o autor este seria um começo adequado para a explicação da diferença quanto a tolerância ao Al destas variedades. Citou ainda que para suportar esta hipótese, outros autores, observaram que quando o $\mathrm{pH}$ da solução nutritiva foi mantido em 4,2 as variedades 'Dayton' e 'Kearney' de cevada se comportaram igualmente sensíveis ao alumínio.

A capacidade de troca de cátions mais baixa das raízes das gramíneas também pode explicar, em parte, a maior tolerância destas plantas à toxidez pelo $\mathrm{Al}^{3+}$, pois o menor valor de CTC das raízes favorece a absorção de cátions monovalentes, em detrimento dos bi ou trivalentes (HELYAR, 1978; FERNANDES et al., 1984). Outro mecanismo de tolerância ao $\mathrm{Al}^{3+}$ citado por HELYAR (1978), envolve a imobilização do alumínio absorvido em complexos orgânicos solúveis ou insolúveis. 
BRENES \& PEARSON (1973), trabalhando com três espécies de gramíneas em dois solos ácidos, Ultisol e Oxisol, observaram grande diferença entre as espécies quanto à tolerância à acidez e ao alumínio tóxico, sendo o capim 'stargrass' (Cynodon plectostachyus) mais tolerante, o milho moderadamente tolerante e o sorgo muito suscetível.

SPAIN \& ANDREW (1976), testaram seis espécies de gramíneas tropicais em quatro níveis de saturação por alumínio em solução nutritiva, pH constante de 4,2 e baixo nível de $\mathrm{P}(0-5 \mathrm{ppm})$. Observaram boa tolerância ao $\mathrm{Al}$ em solução por Brachiaria decumbens, cuja produção de matéria seca foi de 4,65 g/vaso e 5,10 g/vaso para 0 e 4,0 ppm de Al respectivamente. Já o capim colonião apresentou produções de 6,96 $\mathrm{g} /$ vaso e $6,07 \mathrm{~g} / \mathrm{vaso}$ para concentrações de 0 e $4,0 \mathrm{ppm}$ de Al, respectivamente, sugerindo maior sensibilidade desta espécie à toxicidade. O capim-Buffel (Cenchrıs ciliaris) foi seriamente afetado pelo Al. Estes resultados também foram relatados por SPAIN (1979).

FERNANDES et al. (1984) estudaram o comportamento de Brachiaria decumbens e Cenchrus ciliaris em solução nutritiva com níveis de $0 ; 0,75 ; 1,5 ; 3$ e 6 ppm de Al. Corroborando com SPAIN \& ANDREW (1976), concluíram que a espécie Cenchris ciliaris é mais sensível à concentrações de Al. Ambas as espécies mostraram acentuada redução da CTC radicular com níveis crescentes de Al. Na espécie mais tolerante ( $B$. decumbens), essa diminuição da CTC das raízes parece ter favorecido a absorção de $\mathrm{K}^{+}$em relação ao $\mathrm{Ca}^{2+}$. Os autores concluíram que o estudo das relações entre CTC e absorção de nutrientes, numa gama ampla de tolerância diferencial ao Al, seria de grande interesse. 
LOTERO et al. (1971) citam que em um solo ácido da Colômbia e com teores muito baixos de $\mathrm{Ca}$ e $\mathrm{K}$ e alto $\mathrm{Al}$ trocável, doses de 0 e $4 \mathrm{t} / \mathrm{ha}$ de calcário foram estudadas. Aumentos significativos na produção de forragem seca $(1,92 \mathrm{t} / \mathrm{ha})$ e produção de forragem verde (10 t/ha) foram obtidos com aplicação do calcário para capim-jaraguá (Hyparrhenia nufa (Ness.) Stapf.) e capim-elefante (Pennisetum purpureum Schumach) respectivamente e decréscimo da produção de MS do capim-gordura (Melinis minutiflora Beauv) e pangola (Digitaria decumbens Stent), contrariando resultados de WERNER et al. (1967), encontraram ligeiro aumento na produção de MS do capim-colonião (Panicum maximum Jacq.).

Em outra localidade da Colômbia, LOTERO et al. (1971) citam três experimentos com pastagens de jaraguá, gordura e braquiária. Somente na pastagem de braquiária a adição de 2 t/ha de calcário em presença de 50,100 e $100 \mathrm{~kg} / \mathrm{ha}$ de $\mathrm{N}, \mathrm{P}_{2} \mathrm{O}_{5}$ e $\mathrm{K}_{2} \mathrm{O}$, respectivamente resultou em produção de forragem significativamente maior.

Os autores concluíram que os capins jaraguá, pangola e gordura parecem bastantes tolerantes a alta acidez em determinados tipos de solo da Colômbia. O capim-elefante e capim-braquiária responderam mais ou menos satisfatoriamente à aplicação de calcário, principalmente em solos vermelhos de clima médio do Piedemonte Llanero e Llanos Orientais.

\subsubsection{Comportamento do capim Andropogon gayanus}

EMRICH (1972) observou que o capim-andropogon demonstrou considerável resistência à seca e menor exigência quanto à fertilidade e acidez do solo 
quando comparado aos capins jaraguá, gordura, pangola e colonião cultivados em solo de cerrado, num experimento de calagem e doses de $\mathrm{N}, \mathrm{P}$ e $\mathrm{K}$.

Trabalhos conduzidos no CIAT (1978), relatam que níveis de calcário de $0 ; 0,5 ; 2,0$ e $6,0 \mathrm{t} / \mathrm{ha}$, na forma de carbonato de cálcio, foram aplicados em solos com $90,85,50$ e $10 \%$ de saturação por alumínio, respectivamente. Contudo, os rendimentos máximos do capim-andropogon foram obtidos sem aplicação de calcário.

Segundo a Seção de Fertilidade de Solos e Nutrição de plantas do CIAT (1980), foi estabelecido um experimento com diversas gramíneas e leguminosas tropicais, onde doses de $0 ; 0,5 ; 1,0$ e 5,0 t de calcário por ha e doses de $0 ; 17 ; 117$ e 277 $\mathrm{kg}$ de $\mathrm{P} / \mathrm{ha}$ foram aplicados à lanço e incorporados à $20 \mathrm{~cm}$ de profundidade. $\mathrm{O}$ andropogon apresentou boa resposta à aplicação de fósforo, porém se observou efeito variável do calcário na produção de matéria seca. $\mathrm{O}$ trabalho sugere a prática da calagem melhor como forma de adicionar $\mathrm{Ca}^{2+}$ e $\mathrm{Mg}^{2+}$ do que como corretivo.

GOEDERT et al. (1985) abriram trincheira em parcela instalada em solo de cerrado anteriormente calcariado e também trabalharam com experimento em casa de vegetação, com níveis de Ca num Latossolo Vermelho-Escuro, textura argilosa, contendo 0,01 e $1,32 \mathrm{meq} / 100 \mathrm{~g}$ de $\mathrm{Ca}$ e $\mathrm{Al}$ trocáveis, respectivamente. Observaram abundante quantidade de raízes até uma profundidade de $180 \mathrm{~cm}$, concluindo que o capim-andropogon tem capacidade de desenvolver um sistema radicular denso e profundo, mesmo em condições adversas de solo e seu crescimento radicular está correlacionado com o nível de cálcio trocável no solo, indicando que o crescimento de raízes é reduzido quando o nível de cálcio trocável for menor que $0,02 \mathrm{meq} / 100 \mathrm{~g}$. 
PAULINO et al. (1989), trabalhando com níveis de fosfogesso, fósforo e calagem, em condições de casa de vegetação com um solo Latossolo VermelhoEscuro álico, notaram que o capim-andropogon não respondeu à calagem, mostrando maiores produções na ausência de calagem, apresentando portanto, uma boa tolerância à fatores de acidez.

Por outro lado, BARCELLOS \& SANZONOWICZ (1987) observaram que a aplicação de doses de calcário promoveram resposta linear para o andropogon. A matéria seca radicular também foi alterada.

COUTO et al. (1991) trabalharam em condições de campo durante 5 anos com capim-andropogon em solo de cerrado de Planaltina-DF, com fontes de P na ausência ou presença de calcário, avaliando produção de MS/ha. A dose utilizada de 1,5 t/ha de calcário melhorou a resposta ao $\mathrm{P}$. A quantidade requerida do fertilizante fosfatado para produzir 2 t/ha de MS foi reduzida de $180 \mathrm{~kg}$ P/ha para $78 \mathrm{~kg}$ de P/ha com o calcário.

Os autores concluíram ainda que embora tenha levado mais tempo, o capim-andropogon estabeleceu-se sem calcário ou $\mathrm{P}$ no quarto ou quinto ano, alcançando níveis de produtividade similares às parcelas fertilizadas, confirmando sua excelente adaptação a solos ácidos e de baixa fertilidade.

\subsubsection{Comportamento de Brachiaria decumbens, B. humidicola e B. brizantha cv. Marandu}

Em um solo franco-arenoso de Carimagua, Colômbia, LOTERO et al. (1971) relataram experimento onde foram utilizadas doses de 0,4 e 8 toneladas de cal 
agrícola por hectare em pastagem de capim-braquiária (Briachiaria decumbens Stapf.), tendo encontrado aumento de 1,7 t/ha de matéria seca por corte com aplicação de $4 \mathrm{t} / \mathrm{ha}$ do corretivo, em presença de 50,100 e $150 \mathrm{~kg} / \mathrm{ha}$ de $\mathrm{N}, \mathrm{P}_{2} \mathrm{O}_{5}$ e $\mathrm{K}_{2} \mathrm{O}$, respectivamente, não obtendo benefício com a aplicação da dose máxima.

Num experimento em casa de vegetação, SIQUEIRA et al. (1980) trabalharam com um solo Latossolo Vermelho-Amarelo distrófico e álico, inicialmente com $84 \%$ de saturação por $\mathrm{Al}$, aplicando $0 ; 0,8 ; 1,3$ e 4,0 t de $\mathrm{CaCO}_{3} /$ ha, com as gramíneas Brachiaria decum bens, Brachiaria humidicola e Melinis minutiflora e observaram aumento significativo no peso da parte aérea das três gramíneas até o nível de $0,8 \mathrm{t} \mathrm{CaCO}_{3} / \mathrm{ha}$. Citando experimentos subsequentes sugeriram que $\mathrm{Ca}^{2+}$ ou $\mathrm{Ca}^{2+}+\mathrm{Mg}^{2+}$ são mais limitantes ao crescimento das gramíneas estudadas do que a correção da acidez.

Conclusão semelhante para Brachiaria decumbens chegaram PEREIRA (1987) e SANZONOWICZ et al. (1987), para as doses de 2,5 t de calcário em Latossolo Vermelho com vegetação de campo limpo e 3,0 t de calcário em Latossolo Vermelho-Escuro distrófico, respectivamente.

PEREIRA (1987) citou trabalho conduzido no Centro Nacional de Pesquisa de Gado de Corte - CNPGC, onde se compararam produções de matéria seca de seis gramíneas num Latossolo Roxo (sub-solo) nos níveis 0,500 e $1000 \mathrm{~kg}$ de $\mathrm{CaCO}_{3} / \mathrm{ha}$. As produções de MS foram de 3,92 e 5,41; 8,18 e 8,96 e 1,83 e 2,16 g/vaso para $B$. brizantha cv. Marandu, P. maximum cv. comum e A. gayanus, respectivamente para os níveis zero e $1000 \mathrm{~kg} / \mathrm{ha}$ de $\mathrm{CaCO}_{3}$. Assim, o autor também sugeriu que pequenas aplicações de calcário são suficientes para que as braquiárias atinjam rendimentos máximos. 
Trabalhos do CIAT, 1989 com B. brizantha cv. Marandu em solo franco-arenoso evidenciaram resposta linear positiva à calagem até o nível de $930 \mathrm{~kg} / \mathrm{ha}$ de calcário.

Também PREMAZZI (1991), trabalhando com níveis de porcentagem de saturação por bases em forrageiras tropicais em casa de vegetação relatou produção de matéria seca máxima da cultivar Marandu quando o solo atingiu $47 \%$ de saturação por bases para o $2^{\circ}$ corte. Já a produção total de MS por vaso foi obtida quando a V\% atingiu 43 , correspondendo à aplicação de aproximadamente $2,4 \mathrm{t} /$ ha de calcário. No $1^{\circ}$ corte não foram observadas diferenças significativas de produção de M.S. com elevação da saturação por bases.

\subsubsection{Comportamento de Panicum maximum}

WERNER et al. (1967), em ensaios de vasos usando solo com pH 5,8 da Noroeste do Estado de São Paulo não observaram respostas do capim-colonião à calagem. Os autores concluíram que a elevação do $\mathrm{pH}$ pode ter imobilizado certos micronutrientes, promovido retrogradação do fósforo ou que o $\mathrm{pH}$ ideal para $\mathrm{o}$ desenvolvimento da forrageira seria baixo. Neste nível de $\mathrm{pH}$ inicial, parece ser pouco provável que esta gramínea apresente resposta à calagem.

Em outro experimento, com solo do tipo PVA-Laras-álico e com teor médio de Al trocável em capim-colonião estabelecido, WERNER et al. (1979) utilizaram três níveis de calagem $0 ; 1,50$ e 3,375 t de calcário dolomítico/ha. A dose de $1,50 \mathrm{t}$ era 
suficiente para neutralizar o $\mathrm{Al}^{3+}$ e a dose de $3,375 \mathrm{t}$ suficiente para elevar o $\mathrm{pH}$ a $6,5 . \mathrm{O}$ experimento foi conduzido por 3 anos, nos quais foram feitos 11 cortes. A produção de MS e proteína bruta não se alteram positivamente com a calagem. No $3^{\circ}$ ano verificou-se aumento na concentração de cálcio nas plantas com o aumento da dose de calcário. Houve

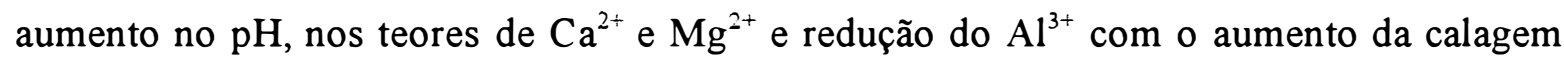
no solo, após dois anos de condução do experimento.

COUTO et al. (1985) estudaram o efeito residual de fósforo e calagem em quatro gramíneas tropicais num Latossolo Vermelho-Escuro, fase cerrado. Observaram que o P. maximum cv. Makueni foi capaz de utilizar o fósforo residual mais eficientemente, produzindo mais que o dobro de MS com o mesmo teor de P no tecido na parcela com calcário se comparada à parcela sem o corretivo.

Num ensaio de três anos de duração em solo arenoso de cerrado, GOMIDE et al. (1986) estudaram os efeitos da calagem, fontes e níveis de fósforo no estabelecimento e produção do capim-colonião. Observaram efeito significativo no $1^{\circ}$ ano apenas para o superfosfato triplo. Entretanto, no $2^{\circ}$ ano diferenças significativas de produção de MS/ha foram observadas apenas para o efeito de calagem, quando este foi incorporado ao solo 3 meses antes do plantio, não havendo efeito quando aplicado em cobertura sobre a pastagem. O teor médio de cálcio na gramínea elevou-se de $0,30 \%$ no $2^{\circ}$ ano para $0,41 \%$ no $3^{\circ}$ ano, sugerindo também aumento na disponibilidade do elemento com o decorrer do tempo. A aplicação do calcário com ou sem incorporação resultou num teor médio de cálcio da forrageira nos últimos 2 anos da ordem de $0,37 \% \pm 0,06 \%$, enquanto na ausência de calcário observou-se o valor médio de $0,32 \pm 0,06 \%$ de $\mathrm{Ca}$. 
JANK et al. (1987) avaliaram, durante 2 anos, 156 ecótipos de Panicum sp. em solos de baixa fertilidade em parcelas sem adubação e com adubação de 1,5 t de calcário dolomítico, $160 \mathrm{~kg}$ de $\mathrm{P}_{2} \mathrm{O}_{5}, 80 \mathrm{~kg}$ de $\mathrm{K}_{2} \mathrm{O}, 40 \mathrm{~kg}$ FTE e $50 \mathrm{~kg} \mathrm{~N}$ por hectare. Cerca de $40 \%$ dos ecótipos estudados apresentaram maior produção anual de matéria seca de folhas e melhor distribuição desta ao longo do ano comparadas ao cultivar "Colonião" utilizado como testemunha. O cultivar "Colonião", sem adubação, produziu metade da produção no solo adubado, sendo superado por $64 \%$ dos ecótipo avaliados.

USBERTI FILHO et al. (1987) trabalharam com diversos híbridos e cultivares de capim-colonião em solução nutritiva com 0,12 e $24 \mathrm{mg} / \mathrm{litro}$ de $\mathrm{Al}^{3+}$ e em ensaios posteriores de campo em solos de comprovada acidez ( $\mathrm{pH}$ em torno de 4,0 ) e baixa fertilidade natural (saturação por bases em torno de 10\%). Os autores citaram que a concentração de $24 \mathrm{mg} \mathrm{Al}$ 3l$^{3+} /$ itro possibilitou boa separação dos materiais quanto à tolerância ao alumínio. Concluíram que os híbridos H-10, H-12 e H-13 mostraram-se altamente tolerantes, com reduções significativas no comprimento médio de raiz apenas na concentração de $24 \mathrm{mg} /$ litro, enquanto o cultivar 'Guiné' revelou-se altamente intolerante. Materiais de ciclo tardio (H-55B, H-71B e cultivar Tobiatã) apresentaram moderada tolerância, enquanto os de ciclo precoce (H-05, H-30, H-42 e cultivar coloninho) mostraram-se intolerantes ao alumínio. Os resultados de campo mostraram boa correlação com os de casa de vegetação, tendo o híbrido H-12 (IAC-Centenário) revelado o melhor desempenho nos ensaios regionais.

BARCELLOS \& SANZONOWICZ (1987) estudaram a resposta ao calcário e fósforo de três cultivares de P. maximum (colonião, CPAC-3148 e CPAC-3273) 
selecionados em condições de baixa fertilidade do solo, comparando-os com o Andropogon gayanus em um Latossolo Vermelho-Escuro argiloso, em casa de vegetação. Todas as gramíneas testadas aumentaram a sua produção de matéria seca com a aplicação de 0,$3 ; 1,2$; 2,$0 ; 2,8$ e 3,7 t/ha e $18 ; 72 ; 120 ; 168$ e $222 \mathrm{~kg} /$ ha de calcário dolomítico e $\mathrm{P}_{2} \mathrm{O}_{5}$, respectivamente. A aplicação de calcário resultou em efeito quadrático para os cultivares de P. maximum. A matéria seca radicular não foi alterada com a aplicação de calcário; o mesmo ocorreu com o número de perfilhos e o teor de $\mathrm{P}$ nos tecidos respectivamente, com exceção para o P. maximum - colonião e $P$. maximum CPAC-3148. Os autores concluíram que a capacidade dos três cultivares de $P$. maximum de se adaptar a acidez do solo foi semelhante.

Por outro lado, HUTTON \& SOUSA (1987), trabalhando com linhagens de Panicum sp. obtidos no CIAT-Colômbia através de seleção para estresse em

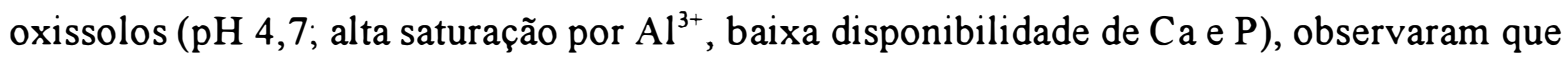
o híbrido CPAC-3148 obteve maior produção de MS em relação aos cultivares controle Makueni e Colonião. O CPAC-3148 produziu $2834 \mathrm{~kg}$ de MS/ha contra $2050 \mathrm{~kg}$ de MS/ha e $900 \mathrm{~kg}$ de $\mathrm{MS} / \mathrm{ha}$ para os cultivares Makueni e Colonião, respectivamente, num experimento sem adubação adicional. O trabalho, concluíram os autores, mostrou a possibilidade de, através do melhoramento, obter-se cultivares de Panicum sp. adaptados a latossolos com baixos níveis de $\mathrm{pH}, \mathrm{P}$ e $\mathrm{Ca}$.

Experimentos em andamento conduzidos pelo CIAT (1990), com Ca $\mathrm{x}$ P x espécies de gramíneas mostraram que P. maximu CPAC 3148 tem apresentado igual comportamento que $B$. brizantha $\mathrm{cv}$. Marandu. Houve forte resposta ao $\mathrm{P}$ e nenhuma resposta quantificável em relação à calagem. 
O cultivar P. maximum CPAC-3148 foi lançado como P. maximum cultivar Vencedor, estudado neste trabalho (LAPOINTE ${ }^{5}$ ).

THOMAS \& LAPOINTE (1989) conduziram experimento de campo com 27 acessos de Panicum maximum, em duas localidades em Carimagua (Colômbia), em um Oxissol de pH 4,8 e saturação por Al de 90\%, sem aplicação de calcário. Em ambos locais, 6 acessos produziram mais matéria seca de folha que os cultivares controles Petrie e Colonião comum. Os acessos CIAT 6799, 6944, 16019 e 16042 foram mais produtivos em ambos locais, cuja variação de textura do solo foi de 7 e $33 \%$ de areia. Os autores concluíram que a identificação de cultivares de Panicum sp. edaficamente adaptados e que também possuam resistência a cigarrinha das pastagens aumentam as opções de plantas forrageiras para serem utilizadas pelo pecuarista.

\subsection{Efeitos da calagem nos níveis de nutrientes em forrageiras tropicais}

Os níveis de minerais nas plantas variam, via de regra, com diversos fatores. Entre eles, a diferença genética entre as espécies e cultivares, o estádio de maturação fisiológica, a época do ano, a parte da planta amostrada, a mobilidade dos nutrientes na planta, a textura e fertilidade natural do solo onde a planta se encontra, o tipo

\footnotetext{
5 LAPOINTE, S. (CIAT, Tropical Pastures Programme, Cali, Colombia). Comunicação pessoal, 1992.
} 
e dosagem do corretivo ou fertilizante utilizado e as interações entre os nutrientes no solo e na planta (OLSEN, 1972; EPSTEIN, 1975; LOURENÇO \& SARTINI, 1982; PAULINO et al., 1987; SOUZA et al., 1989).

A aplicação de calcário provoca profundas alterações no sistema soloplanta (RAIJ, 1981; LOPES, 1984; MARTINEZ et al., 1984). Tanto que, em trabalhos onde doses de calcário são utilizadas, além da matéria seca, alterações nos teores de nutrientes das plantas tem sido relatadas, conforme a espécie estudada.

ABRUÑA \& FIGARELLA (1957), trabalhando num solo ácido de Porto Rico com doses de $\mathrm{P}$ e calcário, não encontraram diferenças no teor de proteína, $\mathrm{Ca}$ e P na parte aérea do colonião nas parcelas calcariadas, mas obtiveram efeito do calcário na produção de matéria seca e teor de proteína para a espécie Kudzu-tropical (Pueraria phaseoloides).

Porém, ABRUÑA et al. (1964), trabalhando com alta dose de fertilizante e níveis de calcário calcítico em capim-napier, colonião e pangola encontraram aumento da percentagem de $\mathrm{Ca}$ e diminuição do Mn nas três gramíneas com o aumento da calagem.

No trabalho de WERNER et al. (1979), o efeito do calcário em capim-colonião foi bem evidente no aumento dos teores de $\mathrm{Ca}$ no $3^{\circ}$ ano de condução do experimento, passando de $0,34 \%$ para $0,42 \%$ na MS nos tratamentos sem calagem e com $3,37 \mathrm{t} / \mathrm{ha}$ do corretivo, respectivamente. A calagem não alterou os teores de $\mathrm{P}$ e proteína bruta da forragem. Já os teores de potássio apresentaram tendência de diminuição no primeiro ano do ensaio, passando de $1,83 \%$ para $1,71 \%$ e no segundo ano, de $2,13 \%$ para 
2,05\% diante da aplicação dos níveis de calcário, respectivamente. Esta diminuição no teor de potássio com o aumento da calagem também foi observado por JONES \& FREITAS (1970), trabalhando com quatro leguminosas forrageiras e por MONTEIRO \& CARRIEL (1987) para colonião com aplicação de gesso.

LIMA \& MATTOS (1982), estudando a composição mineral de cinco cultivares de Stylosanthes em um solo de cerrado paulista constataram que a ausência da calagem provocou aumento nos teores de K, bem como Mn e $\mathrm{Zn}$. Por outro lado, a omissão de $\mathrm{K}^{+}$provocou a elevação nos teores de $\mathrm{Ca}, \mathrm{Mg}, \mathrm{Cu}$ e $\mathrm{Mn}$ em três dos cinco cultivares testados. Sintomas de toxidez pelo Mn em soja-perene (Neonotonia Wheigtii cv. Tinaroo), foram observados por COLOZZA et al. (1983) e MONTEIRO et al. (1983), na ausência de calagem.

Já GOMIDE et al. (1986), trabalhando com calagem e fontes de fósforo em solo arenoso de cerrado observaram do $2^{\circ}$ para o $3^{\circ}$ ano de condução do experimento aumentos nos teores de $\mathrm{Ca}$ no capim colonião de $0,30 \%$ para $0,41 \%$, respectivamente. Os teores de $\mathrm{Mg}$ na matéria seca da gramínia subiram de 0,16\% no segundo ano para $0,20 \%$ no terceiro ano, sugerindo interação entre a calagem e o fosfato de rocha.

CARRIEL et al. (1989) em experimento conduzido em casa de vegetação com os capins Braquiaria decumbens, colonião e gordura verificaram que a omissão de calagem limitou os teores de Ca na parte aérea somente do colonião e os teores de $\mathrm{Mg}$ para todas as gramíneas. O colonião apresentou teores mais elevados de $\mathrm{Ca}$ tanto na presença como na ausência de calagem, com teores mais altos de $\mathrm{Mg}$ que os outros dois 
capins na presença de calagem e mais baixos de $\mathrm{Mg}$ na ausência do corretivo. Com os teores de $\mathrm{K}$ ocorreu fato similar ao verificado com os teores de $\mathrm{Mg}$, contrariando os resultados obtidos por WERNER et al. (1979) e MONTEIRO \& CARRIEL (1987).

COUTO et al. (1991) trabalhando com capim andropogon encontraram aumento na resposta desta gramínea ao fósforo aplicado, sendo as maiores produções observadas nos tratamentos com calcário em todos os níveis de $\mathrm{P}$, exceto o mais baixo. Porém, os dados disponíveis não permitiram concluir se este resultado foi devido à diminuição da fixação do $\mathrm{P}$ pelo solo, melhora na absorção do $\mathrm{P}$ ou efeito da melhor nutrição da planta pelo fornecimento do $\mathrm{Ca}^{2+}$.

PREMAZZI (1991) encontrou efeito de queda nos teores de cobre para Braquiaria brizantha $\left(1^{\circ}\right.$ corte) até o nível de $42 \%$ de saturação por bases, elevando-se em seguida. Já para o colonião ( $1^{\circ}$ corte) observou aumento nos teores deste micronutriente até o nível de $\mathrm{V}=37 \%$ após o qual ocorreu queda. $\mathrm{O}$ teor de ferro na parte aérea no $2^{\circ}$ corte da Braquiaria sp. teve uma diminuição de até V $=34 \%$, a partir de então apresentou tendência de elevação com o aumento da V\%. Os teores de zinco e manganês diminuiram em função da elevação da $\mathrm{V} \%$ para o colonião e brizantha no $1^{\circ}$ e $2^{\circ}$ cortes. Para a brizantha no $2^{\circ}$ corte ocorreram aumentos no teor de boro. Para as outras especies estudadas, efeitos de "diluição" e "concentração" devido à maior e menor produção de MS foram observadas para este micronutriente. 


\section{MATERIAL E MÉTODOS}

O experimento foi conduzido em vasos, na casa de vegetação da Seção de Nutrição de Plantas Forrageiras na Estação Experimental Central do Instituto de Zootecnia em Nova Odessa, SP, no período de outubro de 1990 a março de 1991.

\subsection{Coleta e preparo do solo}

Foram coletados cerca de $500 \mathrm{~kg}$ de solo em outubro de 1990 na fazenda experimental e campus da Universidade de São Paulo/USP/Pirassununga, SP a profundidade de $25 \mathrm{~cm}$ em diversos pontos de um talhão, solo este classificado como Latossolo Vermelho-Escuro, álico, textura argilosa.

O solo foi peneirado, homogeneizado e espalhado sobre lona plástica

para secagem à sombra. Nesta fase foram retiradas três amostras compostas para análise física e química. 
Após o período de secagem, o solo foi colocado em sacos plásticos de forma que coubessem nos vasos. O peso atingido foi de 4,8 $\mathrm{kg}$. Efetuou-se, então, a pesagem de 80 sacos com solo.

\subsection{Incubação do solo com óxidos}

A incubação do solo com óxidos de cálcio e magnésio (tratamentos com calagem) se deu no dia 19/11/1990, com o intuito de atingir $10,30,50$ e $70 \%$ de saturação por bases (V\%), sendo o primeiro nível (ausência de calagem) a V\% original do solo. Os niveis seguintes foram calculados a partir do primeiro, utilizando-se o método do IAC, cuja fórmula é:

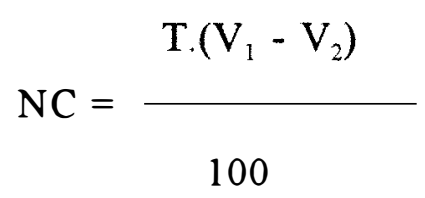

$\mathrm{Na}$ Tabela 1 encontram-se as quantidades dos óxidos de cálcio e magnésio em $\mathrm{g} / \mathrm{vaso}$ e o correspondente em tonelada de calcário/ha que foram utilizadas. 
Tabela 1. Quantidades de óxidos de $\mathrm{Ca}$ e $\mathrm{Mg}$ e correspondente calcário empregados. nos níveis de calagem utilizados.

\begin{tabular}{|c|c|c|c|c|c|}
\hline \multirow{2}{*}{ Trat. } & $\mathrm{V}_{1}$ & $\mathrm{~V}_{2}$ & $\mathrm{CaO}$ & $\mathrm{MgO}$ & \multirow{2}{*}{$\begin{array}{c}\text { Calcário c/23\% } \\
\mathrm{CaO} \text { e } 15 \% \mathrm{MgO} \\
(\mathrm{t} / \mathrm{ha})\end{array}$} \\
\hline & \multicolumn{2}{|c|}{$\%$} & \multicolumn{2}{|c|}{$\mathrm{g} /$ vaso } & \\
\hline 1 & 10 & 10 & - & - & - \\
\hline 2 & 10 & 30 & 1,06 & 0,694 & 2,41 \\
\hline 3 & 10 & 50 & 2,13 & 1,390 & 4,83 \\
\hline 4 & 10 & 70 & 3,20 & 2,080 & 7,25 \\
\hline
\end{tabular}

Após a pesagem dos óxidos, estes foram misturados ao solo agitandoos manualmente, obedecendo o seguinte critério:

- nível 1 - sem calcário: agitados durante 3 minutos;

- níveis 2, 3 e 4 com níveis de calcário: agitados durante 5 minutos. Os sacos plásticos com solo foram acondicionados em vasos de cerâmica previamente impermeabilizados com neutrol. Todos os vasos receberam a adição de 0,9 litros de água destilada de forma a atingir a capacidade de campo do solo. Este valor foi obtido através de teste de capacidade de campo efetuado previamente num vaso mantido exatamente nas mesmas condições dos demais.

Os vasos foram distribuídos em bancas de madeira e cobertos com lona plástica preta, para incubação. Semanalmente foram feitas pesagens de alguns vasos 
escolhidos ao acaso para avaliação da perda de água e cálculo aproximado da reposição. Este procedimento, com duração de 40 dias, seguiu-se até o dia 28/12/1990, quando a lona plástica foi removida e os vasos deixados para secar.

Neste período, 16 amostras de solo compostas foram retiradas, sendo 4 de cada nível de calagem e enviadas ao laboratório para análise química.

\subsection{Espécies estudadas}

Foram utilizadas 5 gramíneas forrageiras tropicais:

- Andropogon gayanus (Hochst) Hack var. bisquamulatus cv.

Planaltina;

- Brachiaria brizantha (Hochst ex A. Rich) Stapf cv. Marandu;

- Panicum maximum Jacq. cv. Colonião IZ-1;

- Panicum maximum cv. Centenário e

- Panicum maximum cv. Vencedor (CPAC-3148,

As sementes do $A$. gayanus e do P. maximum Vencedor procedentes do Centro de Pesquisa Agropecuária dos Cerrados - CPAC/EMBRAPA de Planaltina - DF, e as sementes de B. brizantha, P. maximum cv. IZ-I e P. maximum cv. Centenário procedentes do Instituto de Zootecnia de Nova Odessa. 


\subsection{Delineamento experimental e análises estatísticas}

O experimento foi montado inicialmente com cinco gramíneas e quatro níveis de calcário, com 4 repetições, cujo delineamento estatístico foi o de "blocos casualizados em arranjo fatorial".

Porém, devido ao lento estabelecimento e crescimento do capimandropogon, também observado por THOMAS et al. (1981) e COUTO et al. (1991), seu período de crescimento foi aumentado em 9 dias em relação as outras espécies tanto no $1^{\circ}$ como no $2^{\circ}$ corte; do contrário não se iria obter material da parte aérea suficiente para as análises propostas. Não se prolongou o período de crescimento dos outros cultivares devido às adubações já realizadas e um possível comprometimento do efeito dos tratamentos por limitação de crescimento e devido a insuficiência de outros nutrientes.

Assim a análise estatística foi realizada em arranjo fatorial com 4 espécies e 4 níveis com 4 repetições, e o capim-andropogon foi analisado separadamente, sendo 1 espécie $\times 4$ níveis de calagem com 4 repetições, com delineamento de "blocos casualizados".

Durante todo o período vegetativo as bancas (blocos) foram mudadas de posição semanalmente dentro da casa de vegetação.

As médias dos tratamentos foram comparadas através do teste de Tukey, a $5 \%$ de probabilidade.

Para estudar o comportamento dos capins nos níveis de calcário foram estimadas as equações de regressão para as variáveis estudadas. 


\subsection{Semeadura, adubações e condução do experimento em vasos}

A semeadura foi realizada no dia 03/01/1991, manualmente, em um sulco com aproximadamente $1,0 \mathrm{~cm}$ de profundidade.

A quantidade de sementes foi tal que dependendo do Valor Cultural de cada espécie, garantisse um "stand" inicial de aproximadamente 20 plântulas por vaso. Em seguida realizou-se a cobertura dos sulcos.

A adubação básica levou em consideração os seguintes pontos:

- a análise química inicial do solo;

- a produção de matéria seca provável e sua extração de nutrientes e

- o volume limitado de solo a ser explorado por planta, visto tratar-se de experimento em vasos.

Assim, logo após a semeadura, foram adicionados aos vasos $50 \mathrm{~kg}$ de P/ha e $63 \mathrm{~kg}$ de $\mathrm{K} / \mathrm{ha}$ na forma de $\mathrm{KH}_{2} \mathrm{PO}_{4} ; 2,0 \mathrm{~kg}$ de $\mathrm{Zn} / \mathrm{ha} \mathrm{e} 1,0 \mathrm{~kg}$ de S/ha na forma de $\mathrm{ZnSO}_{4} \cdot 7 \mathrm{H}_{2} \mathrm{O}$, em solução. Seguiu-se a reposição da umidade dos vasos até atingir novamente a capacidade de campo. O nitrogênio e o restante do potássio e enxofre foram adicionados em cobertura.

A germinação se deu no dia 07/01/1991, com exceção da cultivar Centenário, que germinou nos dias 10 e 11/01/1991.

Os desbastes foram realizados a cada três dias, de forma sistemática e gradativa, objetivando sempre a melhor localização e vigor das plantas, obtendo-se "stands" de 20,17, 15, 10, 7 e finalmente 5 plantas por vaso. 
A primeira adubação de cobertura foi realizada no dia 14/01/1991, na forma de $\left(\mathrm{NH}_{4}\right)_{2} \mathrm{SO}_{4}$ p.a. em solução, cujas quantidades de nitrogênio e enxofre foram 50 e $57,1 \mathrm{~kg} / \mathrm{ha}$, respectivamente.

A segunda adubação de cobertura foi realizada no dia 28/01/1991, utilizando-se $\mathrm{KNO}_{3}$ p.a. em solução, cujas quantidades de $\mathrm{N}$ e $\mathrm{K}$ foram 18 e $50 \mathrm{~kg} / \mathrm{ha}$, respectivamente.

As adubações de plantio e cobertura objetivaram a não limitação de nutrientes para o desenvolvimento das plantas.

A contagem do número médio de perfilhos por vaso (número de perfilhos total de cada vaso dividido pelo número de plantas do vaso) foi efetuada semanalmente, e a medição da haste principal de três plantas por vaso (da base da haste até o último nó) foi realizada no dia do $1^{\circ}$ corte.

O primeiro corte foi realizado no dia 05/02/1991 em todas as espécies, com exceção do capim-andropogon, que apresentou extremo retardamento no desenvolvimento vegetativo, sendo cortado 9 dias após. Assim, esta espécie teve 38 dias de crescimento contra 29 dias das demais.

A uma altura de 3 a $4 \mathrm{~cm}$, os cortes foram efetuados em todos os perfilhos visando a não remoção do meristema apical. Porém, os perfilhos principais de cada planta do cultivar Marandu foram removidos.

O material verde de cada vaso foi acondicionado em sacos de papel, seguindo para secagem em estufa com ventilação forçada, onde permaneceram por 60 horas a uma temperatura de $65^{\circ} \mathrm{C}$, até atingirem peso constante. 
O solo foi amostrado no mesmo dia, tomando-se três amostras simples de cada vaso, que foram unidas uma única amostra composta, obtendo-se 80 amostras de solo, uma por repetição, que seguiram para análise química de $\mathrm{pH}$, macronutrientes, acidez potencial $(\mathrm{H}+\mathrm{Al})$, porcentagem de matéria orgânica (M.O.) e alumínio trocável $\left(\mathrm{Al}^{3+}\right)$.

No dia 13/02/1991 foi realizada a primeira adubação de cobertura na rebrota visando a reposição dos nutrientes extraídos. Utilizou-se o $\mathrm{KNO}_{3}$ p.a. em solução cujas quantidades de $\mathrm{N}$ e $\mathrm{K}$ foram 27 e $75 \mathrm{~kg} / \mathrm{ha}$, respectivamente, e ainda o $\left(\mathrm{NH}_{4}\right)_{2} \mathrm{SO}_{4}$ p.a. em solução com o intuito de completar a adubação nitrogenada com $28 \mathrm{~kg} / \mathrm{ha}$, repondo ainda $32 \mathrm{~kg}$ de $\mathrm{S} / \mathrm{ha}$.

Uma segunda adubação foi realizada nos dias 20/02/1991 para os cultivares Marandu, IZ-1, Centenário e Vencedor e 22/02/1991 para o capim-andropogon, utilizando-se o $\mathrm{NH}_{4} \mathrm{NO}_{3}$ p.a. em solução em quantidade equivalente a $55 \mathrm{~kg}$ de $\mathrm{N} / \mathrm{ha}$.

Durante a rebrota, sintomas de doenças foliares, possivelmente helmintosporiose e cercosporiose, foram notados nos cultivares de Panicum, porém não evoluíram, ficando restritas a alguns vasos. Também foi notado um amarelecimento com posterior secamento de folhas mais velhas dos cultivares do gênero Panicum. Atribuiu-se o fato ao excesso de calor e alta luminosidade após um longo período de dias nublados.

O segundo corte foi realizado no dia 05/03/1991, para todas as espécies, com exceção do andropogon, cujo corte foi realizado em 14/03/1991.

A altura do corte foi o mais rente ao solo possível, no colo da planta, com a parte aérea seguindo o mesmo procedimento adotado para o primeiro corte. 
A cada corte foi realizada a contagem do número de perfilhos por planta. Utilizou-se o parâmetro "número total médio de perfilhos/vaso".

O solo foi novamente amostrado, procedendo-se como a amostragem anterior, evitando-se a retirada de terra dos furos realizados anteriormente.

As raízes foram lavadas em água corrente e em seguida colocadas para secar em estufa, a $65^{\circ} \mathrm{C}$ durante 60 horas, em média.

Todas as amostras, após a pesagem para obtenção do parâmetro "produção de matéria seca" em g/vaso, seguiram para a moagem em micromoinho com peneira de 20 "Mesh" e foram acondicionadas em vidros com tampa plástica seguindo para análises químicas no laboratório do Instituto de Zootecnia em Nova Odessa, SP.

A produção de matéria seca total foi obtida pela soma da produção de matéria seca do $1^{\circ}$ e $2^{\circ}$ corte e matéria seca das raízes.

\subsection{Análises químicas da parte aérea e raízes}

$\mathrm{Na}$ parte aérea, em ambos os cortes, foram analisadas o nitrogênio (digestão sulfúrica com catalizadores, destilação em microdestilador e titulação), fósforo (digestão nitro-perclórica e leitura em colorímetro), potássio, cálcio, magnésio, enxofre, ferro, manganês, cobre e zinco (digestão nitro-perclórica e leitura em espectrofotômetro de absorção atômica) e boro (método colorimétrico-curcumina (BATAGLIA et al., 1983).

Nas raízes foi analisado o nitrogênio segundo método acima descrito. 


\subsection{Análises químicas do solo}

As análises químicas foram realizadas para determinação de $\mathrm{H}+\mathrm{Al}$, $\mathrm{Al}^{-3}$ trocável, matéria orgânica e $\mathrm{pH}$ (RAIJ et al., 1987):

- índice de pH em solução $\mathrm{CaCl}_{2}, 0,01 \mathrm{M}$;

- matéria orgânica: oxidação da matéria orgânica do solo por solução

de dicromato de sódio em ácido sulfúrico à frio e posterior determinação colorimétrica;

- H+Al: solução tampão SMP;

- P: extraído pelo método da resina trocadora de íons e determinado colorimetricamente pelo método do molibdênio azul;

- Ca, $\mathrm{Mg}$ e $\mathrm{K}$ : extraídos por resina trocadora de íons, sendo o $\mathrm{Ca}$ e $\mathrm{Mg}$ determinados por espectrofotometria de absorção atômica e o $\mathrm{K}$ por fotometria de chama de emissão;

- Al trocável: extraído por solução de $\mathrm{KCl} 1 \mathrm{~N} \mathrm{pH} \mathrm{7,0} \mathrm{e} \mathrm{determinado}$ através do método titulométrico com solução de $\mathrm{NaOH} 0,02 \mathrm{~N}$. 


\section{RESULTADOS E DISCUSSÃO}

\subsection{Solo}

Os resultados das análises das amostras de solo retirados após o período de 40 dias de incubação com óxidos de cálcio e magnésio (antes do plantio) se encontram na Tabela 2 e Figuras 1 e 2.

Observaram-se efeitos significativos $(\mathrm{p}<0,01)$ das doses de calcário nas características químicas do solo, representadas pelo aumento do $\mathrm{P}$ disponível e diminuição do teor de $\mathrm{K}$ disponível a partir do nível 2 de calcário onde $\mathrm{V}=37,95 \%$ tornando-se constante até o nível mais elevado de calagem, no aumento do $\mathrm{pH}$, diminuição na acidez potencial $(\mathrm{H}+\mathrm{Al})$ e teores de $\mathrm{Al}^{+3}$ e elevação dos níveis de saturação por bases V\%, desde o nível 2 até o último nível utilizado.

Tais alterações nas características do solo são relatadas pela literatura, com alguma variação, quando se estuda o uso de calagem em solos tropicais (WERNER et al., 1967; JONES \& FREITAS, 1970; WERNER et al., 1979; COUTO et al., 1985; GOEDERT et al., 1985; PAULINO et al., 1989 e PREMAZZI, 1991 ). 
Tabela 2. Resultado da análise química do solo realizada 40 dias após incubação (médias de 4 repetições).

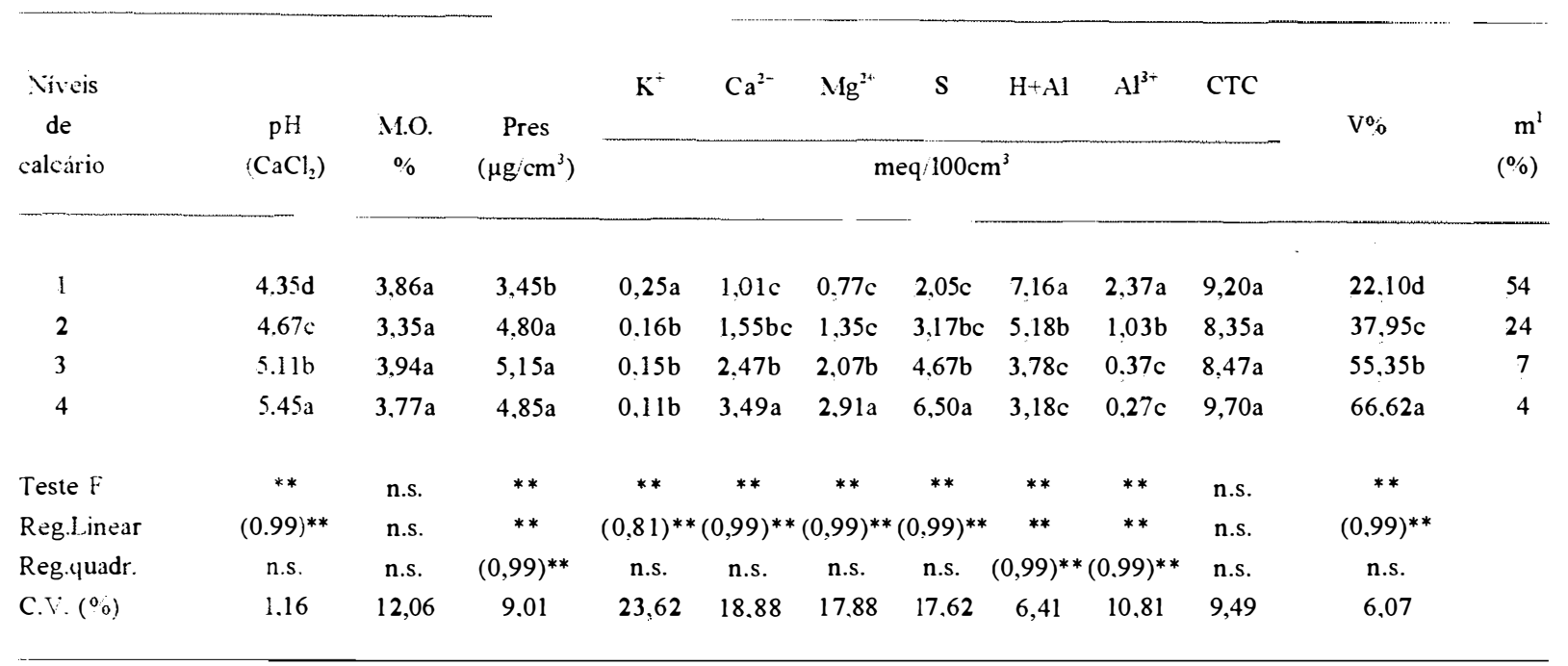

Níveis de significància: ** $1 \%$ * 5\%; n.s. não significativo.

${ }^{1}$ Calculado pela fórmula $100 . \mathrm{Al}^{3+} /\left(\mathrm{S}+\mathrm{Al}^{3+}\right)$.

Os valores entre parénteses indicam o coeficiente de determinação $R^{2}$ para a equação.

Médias seguidas pela mesma letra, dentro de cada coluna. não diferem entre si pelo teste de Tukey $5 \%$.

Tabela 3. Resultados da análise química do solo em amostras coletadas após o $1^{\circ}$. corte para os cultivares Colonião IZ-1. Vencedor, Centenário e Marandu (médias de 16 observações).

\begin{tabular}{|c|c|c|c|c|c|c|c|c|c|c|c|c|}
\hline $\begin{array}{l}\text { Niveis } \\
\text { de } \\
\text { calcírio }\end{array}$ & $\begin{array}{c}\mathrm{pH} \\
\left(\mathrm{CaCl}_{2}\right)\end{array}$ & $\begin{array}{c}\text { M.O. } \\
\%\end{array}$ & $\begin{array}{c}\text { Pres } \\
\left(\mu \mathrm{g} / \mathrm{cm}^{3}\right)\end{array}$ & $\mathrm{K}^{+}$ & $\mathrm{Ca}^{2+}$ & $\mathrm{Mg}^{2+}$ & $e q / 100 c$ & $\mathrm{H}+\mathrm{Al}$ & $\mathrm{Al}^{3+}$ & CTC & $V \%$ & $\begin{array}{r}\mathrm{m}^{\mathrm{I}} \\
(\%)\end{array}$ \\
\hline & & $\cdot$ & & & & & & & & & & \\
\hline 1 & $4.28 \mathrm{~d}$ & $3,46 a$ & $16,54 a$ & $0,13 \mathrm{a}$ & $1,08 \mathrm{~d}$ & $0,64 d$ & $1,85 \mathrm{~d}$ & $4,79 a$ & $2,33 a$ & $6,65 b$ & $30,81 \mathrm{~d}$ & 54 \\
\hline 2 & $4.49 c$ & $3,58 \mathrm{a}$ & $18,24 \mathrm{a}$ & $0,14 a$ & $1,86 \mathrm{c}$ & $1,19 c$ & $3,19 c$ & $3,92 \mathrm{ab}$ & $1,30 \mathrm{~b}$ & $7,14 b$ & $45,81 \mathrm{c}$ & 29 \\
\hline 3 & $4.82 b$ & $3,68 \mathrm{a}$ & $16,58 \mathrm{a}$ & $0,13 \mathrm{a}$ & $2.68 \mathrm{~b}$ & $1,72 b$ & $4,54 b$ & $3,38 \mathrm{bc}$ & $0,51 \mathrm{c}$ & $7,92 \mathrm{ab}$ & $57.03 b$ & 10 \\
\hline 4 & $5.20 \mathrm{a}$ & $3,44 a$ & $15,97 a$ & $0,15 a$ & $3,68 \mathrm{a}$ & $2,40 a$ & $6.24 a$ & $2,79 c$ & $0,23 d$ & $9,03 \mathrm{a}$ & $68,83 \mathrm{a}$ & 3 \\
\hline Teste F & $* *$ & n.s. & n.s. & n.s. & $* *$ & $* *$ & $* *$ & $* *$ & $* *$ & $* *$ & $* *$ & \\
\hline Reg.linear & $* *$ & n.s. & n.s. & $(0,78)^{*}$ & $(0,99)^{* *}$ & $(0,99)^{* *}$ & $(0,99)^{* *}$ & $(0,99)^{* *}$ & $* *$ & $(0,97)^{* *}$ & $(0,99)^{* *}$ & \\
\hline Reg. quadr & $(0.99)^{* *}$ & n.s. & n.s. & n.s. & n.s. & n.s. & n.s. & n.s. & $(0,99)^{* *}$ & * n.s. & n.s. & \\
\hline C.V. $\left({ }^{\circ} \%\right)$. & 2.64 & 8.44 & 15,72 & 19,69 & 23,32 & 24,95 & 22,86 & 30.58 & 14,42 & 18,30 & 19,42 & \\
\hline
\end{tabular}

Niveis de significància: ** $1 \%$ : $5 \%$; n.s. não significativo.

${ }^{1}$ Calculado pela fómula $100 \cdot \mathrm{Al}^{3+}\left(\mathrm{S}+\mathrm{Al}^{3+}\right)$.

Os valores entre parènteses indicam o coeficiente de determinação $\mathrm{R}^{2}$ para a equação.

Médias seguidas pela mesma letra, dentro de cada coluna, não difierem entre si pelo teste de Tukey $5 \%$. 

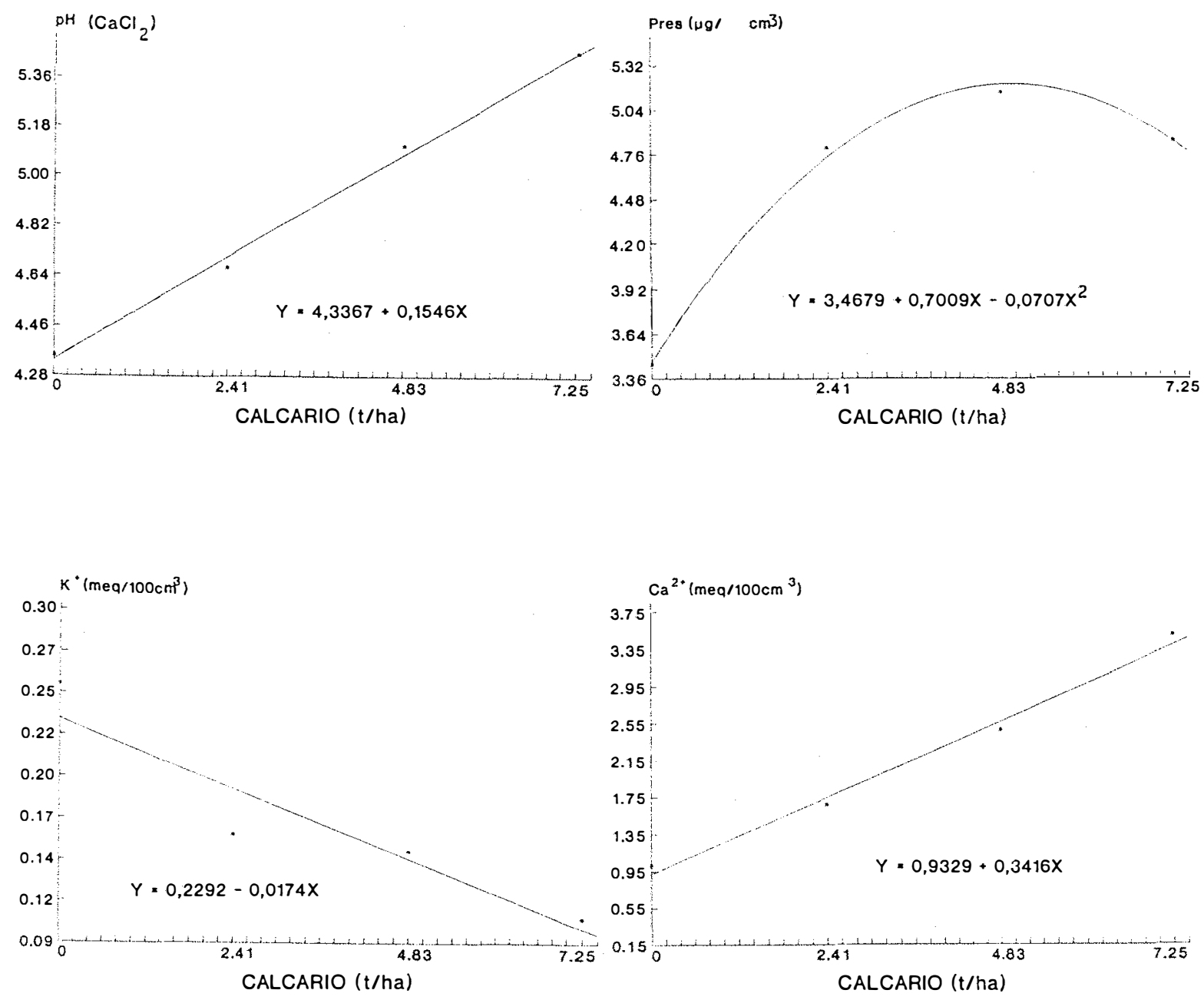

Figura 1. Efeito dos níveis de calcário no $\mathrm{pH}, \mathrm{P}, \mathrm{K}$ e $\mathrm{Ca}^{2+}$ do solo 40 dias após a incubação com óxidos de cálcio e magnésio. 

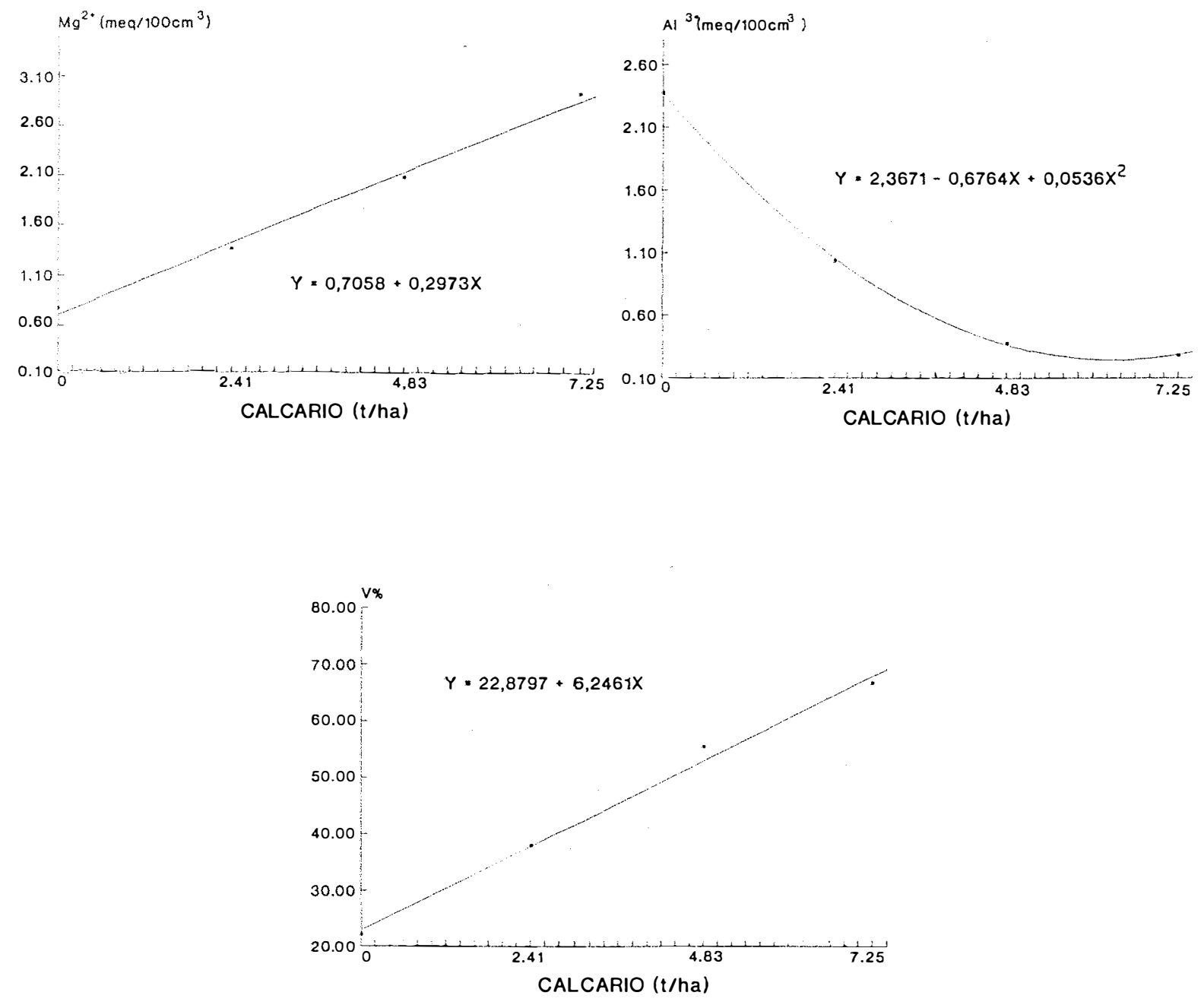

Figura 2. Efeito dos níveis de calcário no $\mathrm{Mg}^{2+}, \mathrm{Al}^{3+}$ e $\mathrm{V} \%$ do solo 40 dias após a incubação com óxidos de cálcio e magnésio. 
Todavia, a ausência de calcário, que refletia a V\% original do solo quando este foi coletado $(\mathrm{V}=10 \%)$ quando do plantio apresentou $22,10 \%$ de saturação por bases. Atribuiu-se esta diferença à variação de resultados entre laboratórios, pois as análises iniciais foram efetuadas em laboratórios distintos ao das demais análises, ainda que ambos utilizassem a mesma metodologia.

Assim os valores de V\% obtidos 22,10\%, 37,95\%, 55,35\% e 66,62\% foram diferentes dos propostos em todos os tratamentos $10 \%, 30 \%, 50 \%$ e $70 \%$, respectivamente, por ocasião do plantio.

Somente a partir do nível 3 com $V=55,35 \%$ (Tabela 2) houve neutralização do $\mathrm{Al}^{+3}$ a níveis considerados não tóxicos (abaixo de $0,5 \mathrm{meq} / 100 \mathrm{~cm}^{3}$ ) em solos cultivados com pastagem de acordo com WERNER (1986).

Resultados semelhantes foram obtidos para as análises de solo realizadas a cada corte. Houveram aumentos altamente significativos do teor de $\mathrm{Ca}$ e $\mathrm{Mg}$, no $\mathrm{pH}$, na $\mathrm{S}$, e na $\mathrm{V} \%$ com a elevação dos níveis de calcário, bem como a diminuição da acidez potencial $(\mathrm{H}+\mathrm{Al})$ e teores de $\mathrm{Al}^{+3}$, em todas as espécies (Tabelas 3, 4, 5, 6 e 7 e Figuras de 3 a 6 ). No solo onde foi cultivado o capim-andropogon houve aumento altamente significativo do teor de $\mathrm{K}$ com o aumento da calagem no $1^{\circ}$. corte (Tabela 4 ).

A análise do solo onde foram cultivados os cultivares Colonião IZ-1, Vencedor, Centenário e Marandu revelaram ocorrer interação significativa para níveis de calcário e espécies quanto ao $\mathrm{P}$ e $\mathrm{K}$ disponível no solo no $1^{\circ}$. corte (Tabela 7). Comparando-se os solos quanto ao teor de $\mathrm{P}$ dentro de cada nível de saturação por bases atingido e os cultivares estudados notou-se que com V $=30,81 \%$ os solos dos cultivares 
Tabela 4. Resultados da análise química do solo em amostras coletadas após o $1^{\circ}$. para o capim-andropogon (médias de 4 repetiçōes).

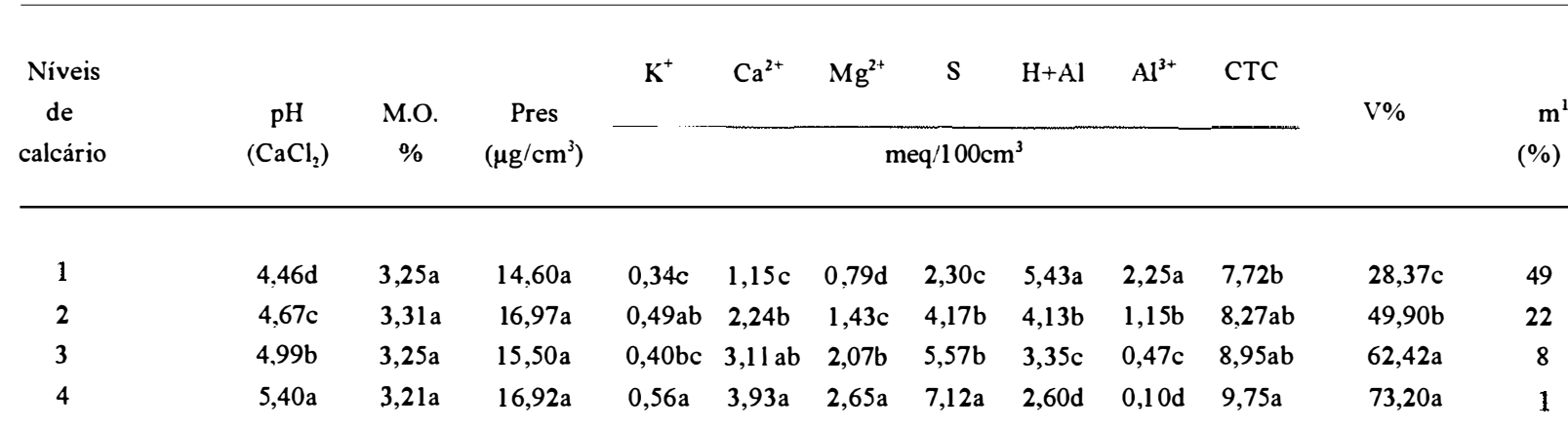

Teste F

Reg.linear

Reg.quadr.

C.V. (\%)

$\begin{array}{cc}* * & \text { n.s. } \\ * * & \text { n.s } \\ (1,00)^{*} & \text { n.s } \\ 1.61 & 16,0\end{array}$

$1,61 \quad 16,01$

\begin{abstract}
n.s.
\end{abstract}
n.s.

n.s.

14,05 $\begin{array}{ccccc}* * & * * & * * & * * & * * \\ & * * 61)^{* *}(0,99)^{* *}(0,99)^{* *}(0,99)^{* *}(0,98)^{* *} & * * & (0,99)^{* *}\end{array}$

$(0,97)^{* *}$

n.s. n.s. n.s. n.s. n.s. $(0,99)^{* *}$ n.s. n.s.

$\begin{array}{llllllll}12,70 & 16,87 & 14,68 & 13,69 & 7,33 & 10,64 & 7,84 & 10,40\end{array}$

Níveis de significància: ${ }^{* *} 1 \%$; ${ }^{*} 5 \%$; n.s. não significativo.

${ }^{1}$ Calculado pela förmula $100 . \mathrm{Al}^{3+} /\left(\mathrm{S}+\mathrm{Al}^{3+}\right)$.

Os valores entre parênteses indicam o coeficiente de determinação $R^{2}$ para a equação.

Médias seguidas pela mesma letra, dentro de cada coluna, não difierem entre si pelo teste de Tukey $5 \%$.

Tabela 5. Resultados da análise química do solo em amostras coletadas após o $2^{\circ}$. corte para os cultivares Colonião IZ-1, Vencedor, Centenário e Marandu (médias de 16 repetiçòes).

\begin{tabular}{|c|c|c|c|c|c|c|c|c|c|c|c|c|}
\hline \multirow{2}{*}{$\begin{array}{l}\text { Niveis } \\
\text { de } \\
\text { calcário }\end{array}$} & \multirow{2}{*}{$\begin{array}{c}\mathrm{pH} \\
\left(\mathrm{CaCl}_{2}\right)\end{array}$} & \multirow{2}{*}{$\begin{array}{c}\text { M.O. } \\
\%\end{array}$} & \multirow{2}{*}{$\begin{array}{c}\text { Pres } \\
\left(\mu \mathrm{g} / \mathrm{cm}^{3}\right)\end{array}$} & $\mathrm{K}^{+}$ & $\mathrm{Ca}^{2+}$ & $\mathrm{Mg}^{2+}$ & $S$ & $\mathrm{H}+\mathrm{Al}$ & $\mathrm{Al}^{3+}$ & CTC & \multirow[t]{2}{*}{ V\% } & \multirow{2}{*}{$\begin{array}{r}\mathrm{m}^{1} \\
(\%)\end{array}$} \\
\hline & & & & \multicolumn{7}{|c|}{$\mathrm{meq} / 100 \mathrm{~cm}^{3}$} & & \\
\hline 1 & $4,40 \mathrm{~d}$ & $3,15 \mathrm{a}$ & $13,36 \mathrm{a}$ & $0,13 \mathrm{a}$ & $1,09 \mathrm{~d}$ & $0,71 d$ & $1,99 \mathrm{~d}$ & $5,42 \mathrm{a}$ & $2,38 \mathrm{a}$ & $7,25 \mathrm{c}$ & $27.84 d$ & 54 \\
\hline 2 & $4,60 \mathrm{c}$ & $3,21 \mathrm{a}$ & $14,00 \mathrm{a}$ & $0,14 \mathrm{a}$ & $1,81 \mathrm{c}$ & $1,09 c$ & $3,05 \mathrm{c}$ & $4,22 \mathrm{~b}$ & $1,36 \mathrm{~b}$ & $7,26 c$ & $42,07 \mathrm{c}$ & 32 \\
\hline 3 & $4,90 \mathrm{~b}$ & $3,10 \mathrm{a}$ & $15,06 \mathrm{a}$ & $0,12 a$ & $2,82 b$ & $1,69 b$ & $4,65 b$ & $3,48 c$ & $0,53 c$ & $8,12 b$ & $57.16 \mathrm{~b}$ & 11 \\
\hline 4 & $5,17 \mathrm{a}$ & $3,22 \mathrm{a}$ & $15,52 \mathrm{a}$ & $0,13 \mathrm{a}$ & $3,85 \mathrm{a}$ & $2,37 \mathrm{a}$ & $6,36 \mathrm{a}$ & $2,79 c$ & $0,26 \mathrm{~d}$ & $9,16 \mathrm{a}$ & $69,56 \mathrm{a}$ & 4 \\
\hline Teste F & $* *$ & n.s. & n.s. & n.s. & ** & ** & $* *$ & ** & $* *$ & $* *$ & $* *$ & \\
\hline Reg.linear & $(0,99)^{* *}$ & n.s. & $(0,98)^{*}$ & n.s. & $(0,99)^{* *}$ & $* *$ & $(0,99)^{* *}$ & $(0,99)^{* *}$ & $* *$ & $* *$ & $(0,99)^{* *}$ & \\
\hline Reg.quadr. & n.s. & n.s. & n.s. & n.s. & n.s. & $(0,99)^{* *}$ & n.s. & n.s. & $(0,99)^{* *}($ & $(0,99)^{* *}$ & n.s. & \\
\hline C.V. $(\%)$ & 1,86 & 7,62 & 20,51 & 16,81 & 17,77 & 20,34 & 16,92 & 18,81 & 17,33 & 11,14 & 13,76 & \\
\hline
\end{tabular}

Níveis de significância: ${ }^{* *} 1 \% ; * 5 \%$; n.s. não significativo.

${ }^{1}$ Calculado pela fórmula $100 . \mathrm{Al}^{3+} /\left(\mathrm{S}+\mathrm{Al}^{3+}\right)$.

Os valores entre parênteses indicam o coeficiente de determinação $R^{2}$ para a equação.

Médias seguidas pela mesma letra, dentro de cada coluna, não difierem entre si pelo teste de Tukey $5 \%$. 
Tabela 6. Resultados da análise química do solo em amostras coletadas após o $2^{\circ}$. corte para o capim-andropogon (médias de 4 repetições).

\begin{tabular}{|c|c|c|c|c|c|c|c|c|c|c|c|c|}
\hline \multirow{2}{*}{$\begin{array}{l}\text { Níveis } \\
\text { de } \\
\text { calcário }\end{array}$} & \multirow{2}{*}{$\begin{array}{c}\mathrm{pH} \\
\left(\mathrm{CaCl}_{2}\right)\end{array}$} & \multirow{2}{*}{$\begin{array}{c}\text { M.O. } \\
\%\end{array}$} & \multirow{2}{*}{$\begin{array}{c}\text { Pres } \\
\left(\mu \mathrm{g} / \mathrm{cm}^{3}\right)\end{array}$} & $\mathrm{K}^{+}$ & $\mathrm{Ca}^{2+}$ & $\mathrm{Mg}^{2+}$ & $S$ & $\mathrm{H}+\mathrm{Al}$ & $\mathrm{Al}^{3+}$ & СТC & \multirow[t]{2}{*}{$\mathrm{V} \%$} & \multirow{2}{*}{$\begin{array}{r}\mathrm{m} \\
(\%)\end{array}$} \\
\hline & & & & \multicolumn{7}{|c|}{$\mathrm{meq} / 100 \mathrm{~cm}^{3}$} & & \\
\hline 1 & $4,31 d$ & $3,61 \mathrm{a}$ & $10,42 a$ & $0,23 \mathrm{a}$ & $0,99 c$ & $0,61 \mathrm{c}$ & $1,85 \mathrm{c}$ & $6,65 a$ & $2,75 \mathrm{a}$ & $8,50 \mathrm{a}$ & $21,55 \mathrm{~d}$ & 60 \\
\hline 2 & $4.62 \mathrm{c}$ & $3,38 \mathrm{ab}$ & $12,55 \mathrm{a}$ & $0.22 \mathrm{a}$ & $2,04 b c$ & $1,47 \mathrm{bc}$ & $3,75 b c$ & $4,85 \mathrm{~b}$ & $1,12 b$ & $8,60 \mathrm{a}$ & $43,57 \mathrm{c}$ & 30 \\
\hline 3 & $4,90 \mathrm{~b}$ & $3,20 \mathrm{~b}$ & $12.92 \mathrm{a}$ & $0,32 a$ & $2,96 \mathrm{ab}$ & $2,11 \mathrm{ab}$ & $5,40 \mathrm{ab}$ & $4,05 \mathrm{c}$ & $0,61 \mathrm{c}$ & $9,45 \mathrm{a}$ & $57.12 b$ & 10 \\
\hline 4 & $5,31 \mathrm{a}$ & $3,13 b$ & $15,87 \mathrm{a}$ & $0,25 \mathrm{a}$ & $4,11 \mathrm{a}$ & $2,79 \mathrm{a}$ & $7,15 a$ & $3,10 d$ & $0,29 d$ & $10,25 \mathrm{a}$ & $69,05 \mathrm{a}$ & 4 \\
\hline Teste $\mathrm{F}$ & $* *$ & * & n.s. & n.s. & $* *$ & $* *$ & $* *$ & $* *$ & $* *$ & n.s. & $* *$ & \\
\hline Reg.linear & $(0,99)^{* *}$ & $(0,95)^{* *}$ & $(0,84)^{*}$ & n.s. & $(0,99)^{* *}$ & $(0,99)^{* *}($ & $(0,99)^{* *}$ & $* *$ & $* *$ & $(0,92)^{*}$ & $(0,98)^{* *}$ & \\
\hline Reg.quadr. & n.s. & n.s. & n.s. & n.s. & n.s. & n.s. & n.s. & $(0,99)^{* *}$ & $(0,99)^{* *}$ & n.s. & n.s. & \\
\hline C.V. $(\%)$ & 1,77 & 4,92 & 23.74 & 19,63 & 22,40 & 28,20 & 23,19 & 6.79 & 10,04 & 10,32 & 9.83 & \\
\hline
\end{tabular}

Níveis de significància: ** $1 \% ; * 5 \%$; n.s. não significativo.

${ }^{1}$ Calculado pela förmula $100 . \mathrm{Al}^{3+} /\left(\mathrm{S}+\mathrm{Al}^{3+}\right)$.

Os valores entre parènteses indicam o coeficiente de determinação $R^{2}$ para a equação.

Médias seguidas pela mesma letra. dentro de cada coluna. não difierem entre si pelo teste de Tukey $5 \%$.

Tabela 7. Teores dos nutrientes fósforo e potássio do solo nos niveis de calcário para os cultivares Colonião IZ-1. Vencedor, Centenário e Marandu no $1^{\circ}$. corte (médias de 4 repetições).

Níveis de calcário

\begin{tabular}{|c|c|c|c|c|c|c|c|c|c|c|}
\hline \multirow[t]{2}{*}{ Cultivares } & \multicolumn{5}{|c|}{$\mathrm{P}\left(\mu \mathrm{g} / \mathrm{cm}^{3}\right)$} & \multicolumn{5}{|c|}{$\mathrm{K}\left(\mathrm{meq} / \mathrm{cm}^{3}\right)$} \\
\hline & $\begin{array}{l}\text { Média de } \\
16 \text { repet. }\end{array}$ & 1 & 2 & 3 & 4 & $\begin{array}{l}\text { Média de } \\
16 \text { repet. }\end{array}$ & 1 & 2 & 3 & 4 \\
\hline Col. IZ-1 & $15,65 \mathrm{~b}$ & $15,35 \mathrm{~b}$ & $16,75 \mathrm{a}$ & $15,25 b c$ & $15,25 \mathrm{ab}$ & $0,12 b$ & $0,12 b$ & $0,13 \mathrm{a}$ & $0,12 \mathrm{ab}$ & $0,11 \mathrm{~b}$ \\
\hline Vencedor & $14.59 \mathrm{~b}$ & $16,35 b$ & $16,22 \mathrm{a}$ & $12,57 \mathrm{c}$ & $13,20 \mathrm{~b}$ & $0,12 b$ & $0,12 b$ & $0,13 \mathrm{a}$ & $0,12 \mathrm{ab}$ & $0,1 \mathrm{lb}$ \\
\hline Centenário & $17,06 \mathrm{~b}$ & $12,55 \mathrm{~b}$ & $19,15 \mathrm{a}$ & $18,12 \mathrm{ab}$ & $18,42 \mathrm{a}$ & $0,13 b$ & $0,13 b$ & $0,13 \mathrm{a}$ & $0,11 \mathrm{~b}$ & $0,18 \mathrm{a}$ \\
\hline Marandu & $20,03 a$ & $21,92 \mathrm{a}$ & $20,82 a$ & $20,37 \mathrm{a}$ & $17,00 \mathrm{ab}$ & $0,17 \mathrm{a}$ & $0,17 \mathrm{a}$ & $0,16 \mathrm{a}$ & $0,17 \mathrm{a}$ & $0,20 \mathrm{a}$ \\
\hline Teste F & $* *$ & - & - & . & - & $* *$ & - & - & - & - \\
\hline C.V. (\%) & 15,73 & - & - & - & - & 19,69 & - & - & - & - \\
\hline
\end{tabular}

Teste $\mathrm{F}$ para a interação niveis $\mathrm{x}$ cultivares: *

Niveis de significància: ${ }^{* *} 1 \%$; * $5 \%$; n.s. não significativo.

Médias seguidas pela mesma letra, dentro de cada coluna, não difierem entre si pelo teste de Tukey $5 \%$. 

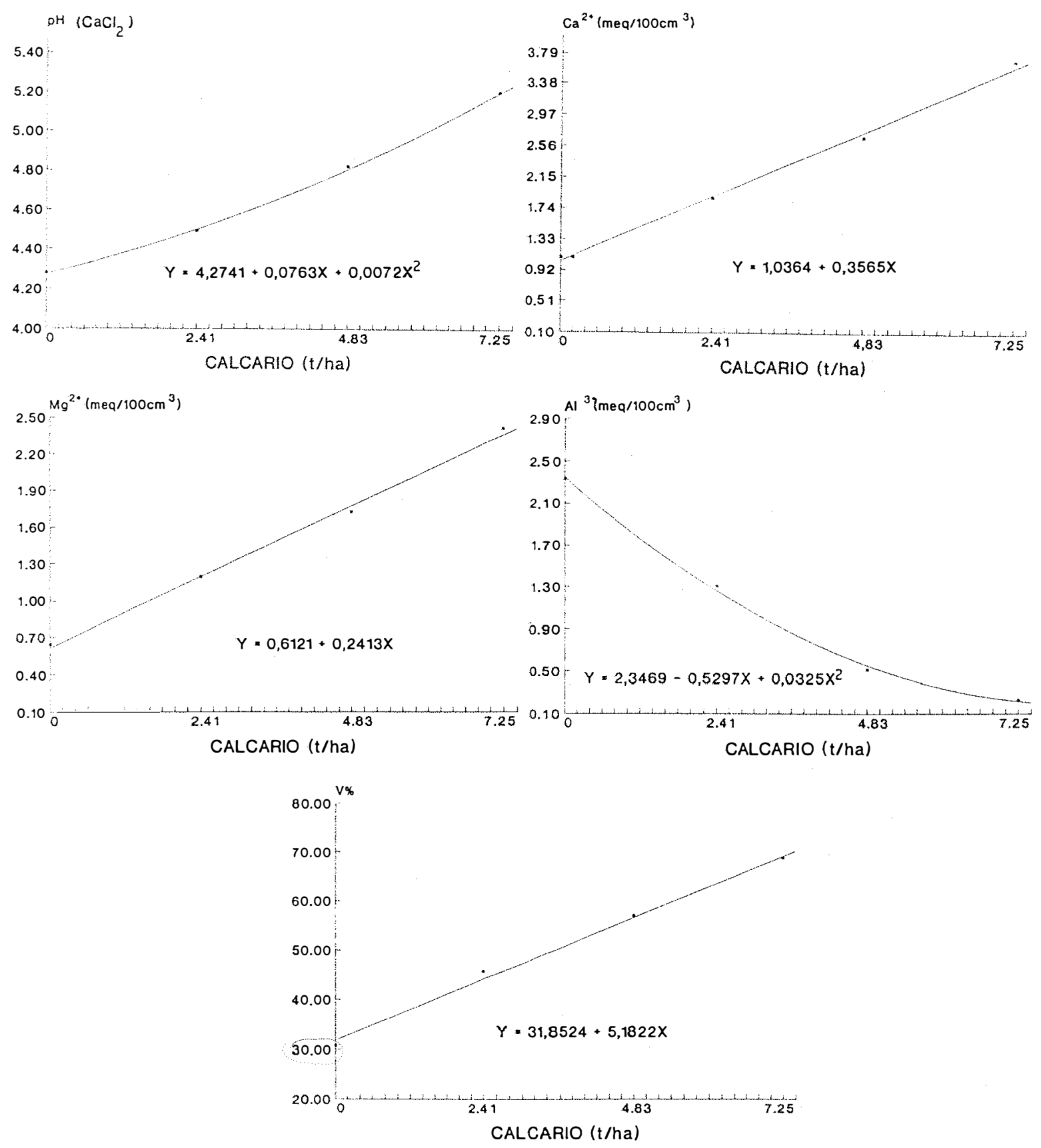

Figura 3. Efeito dos níveis de calcário no $\mathrm{pH}, \mathrm{Ca}^{2+}, \mathrm{Mg}^{2+}, \mathrm{Al}^{3+}$ e $\mathrm{V} \%$ do solo com os cultivares Colonião IZ-1, Vencedor, Centenário e Marandu no $1^{\circ}$. corte. 

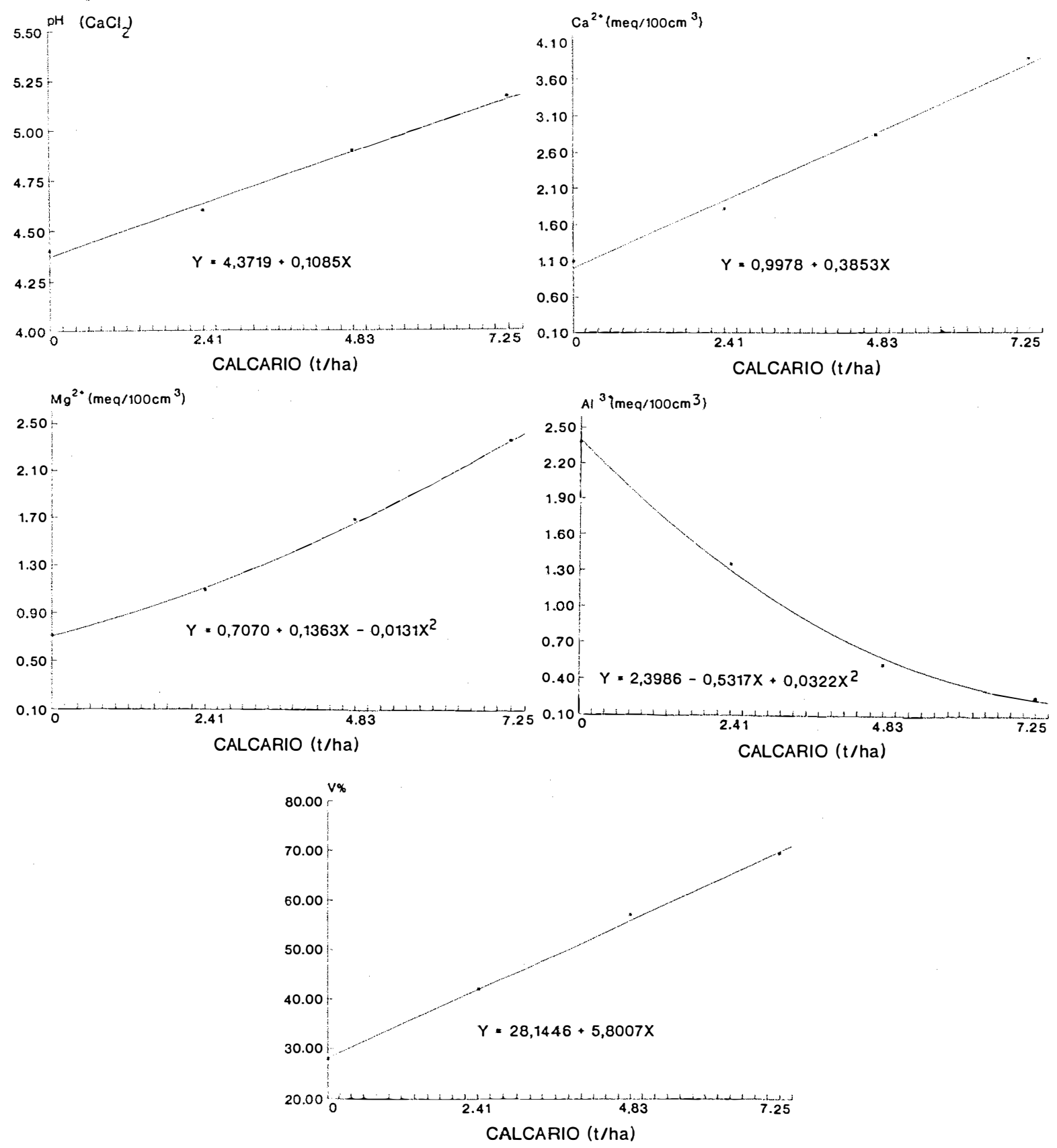

Figura 4. Efeito dos níveis de calcário no $\mathrm{pH}, \mathrm{Ca}^{2+}, \mathrm{Mg}^{2+}, \mathrm{Al}^{3+}$ e $\mathrm{V} \%$ do solo com os cultivares Colonião IZ-1, Vencedor, Centenário e Marandu no $2^{\circ}$. corte. 

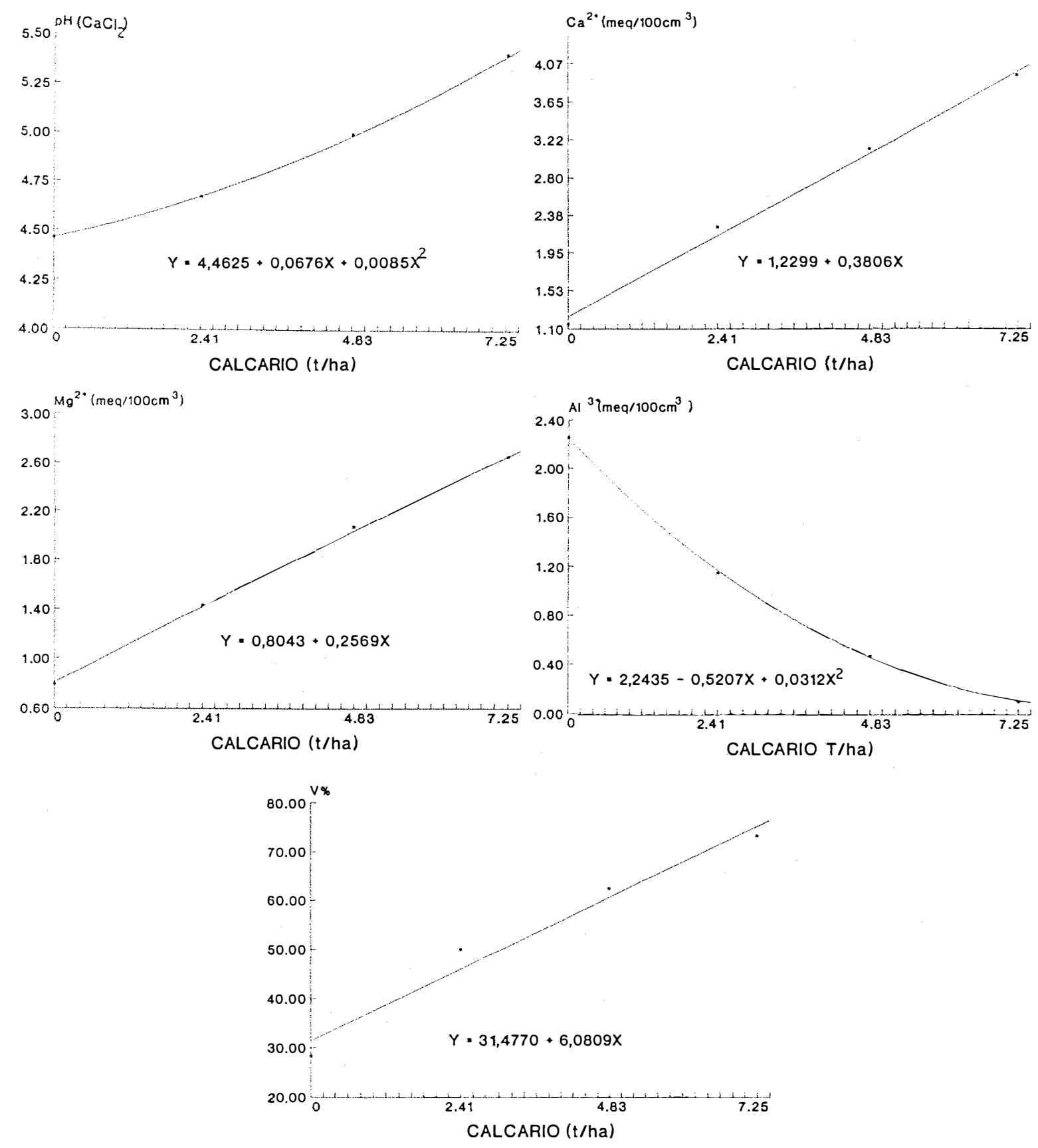

Figura 5. Efeito dos níveis de calcário no $\mathrm{pH}, \mathrm{Ca}^{2+}, \mathrm{Mg}^{2+}, \mathrm{Al}^{3+}$ e $\mathrm{V} \%$ do solo com capim-andropogon no $1^{\circ}$. corte. 

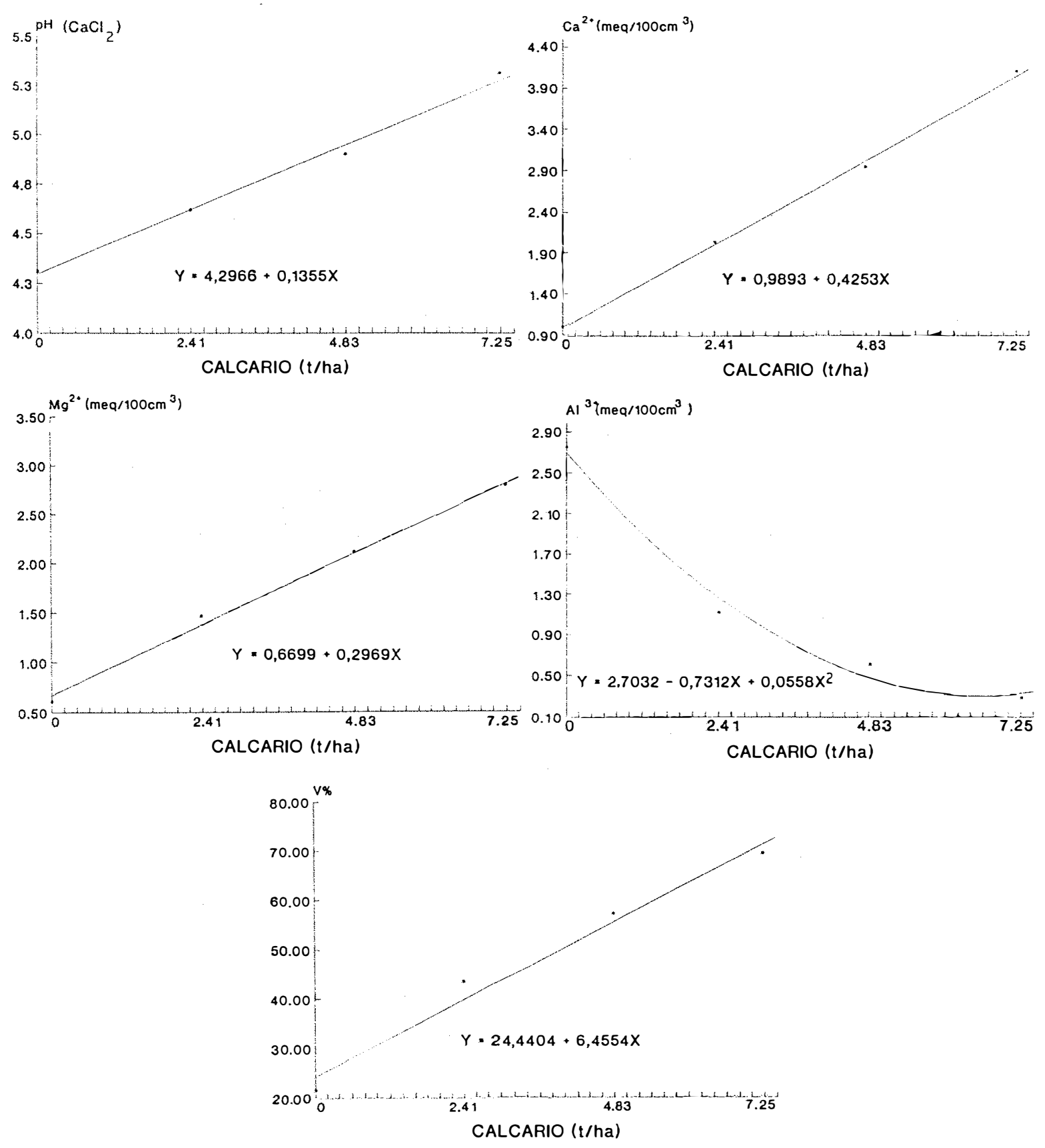

Figura 6. Efeito dos níveis de calcário no $\mathrm{pH}, \mathrm{Ca}^{2+}, \mathrm{Mg}^{2+}, \mathrm{Al}^{3+}$ e $\mathrm{V} \%$ do solo com capim-andropogon no $2^{\circ}$. corte. 
de Panicum maximum apresentaram menor teor de $\mathrm{P}$ do que o solo cultivado com a $B$. brizantha $\mathrm{cv}$. Marandu. Com $\mathrm{V}=45,81 \%$ não houve diferenças significativas; porém com $\mathrm{V}=57,03 \%$ os solos cultivados com o IZ-1 e Vencedor apresentaram menor teor de $\mathrm{P}$, que os solos com Centenário e Marandu. Os solos com estes dois cultivares não diferiram entre si significativamente. No mais elevado nível de saturação por bases $\mathrm{V}=68,83 \%$ o solo com o cultivar Vencedor apresentou menor teor de $\mathrm{P}$ que o solo cultivado com o cultivar Centenário.

Os resultados das análises de solo para $\mathrm{K}^{+}$(Tabela 7), revelaram uma maior disponibilidade deste nutriente no solo cultivado com o Marandu no $1^{\circ}$. corte, com $\mathrm{V}=30,81 \%$. No nível mais elevado de calcário $\mathrm{V}=68,83 \%$ os solos cultivados com Vencedor e Colonião IZ-1 apresentaram menor teor de K disponível (Tukey 5\%).

\subsection{Planta}

\subsubsection{Produção de matéria seca - Parte aérea e total}

Observou-se efeito significativo $(\mathrm{p}<0,01)$ para os níveis de calcário e para os cultivares Colonião IZ-1, Vencedor, Centenário e Marandu com relação à produção de M.S. da parte aérea e matéria seca total em g/vaso (Tabela 8).

No $1^{\circ}$. corte estes cultivares diminuiram a produção de M.S. de forma linear conforme a equação $Y=11,3697$ - 0,3058X (Figura 7). Não houveram diferenças significativas para os dois primeiros níveis de calcário. O mesmo aconteceu para a matéria 
seca total, representada pela equação de regressão polinomial $\mathrm{Y}=30,1606-0,3878 \mathrm{X}$ (Figura 7). Fatos semelhantes são relatados por WERNER et al. (1967); WERNER et al. (1979) e CIAT (1990).

Independente do nível de calcário utilizado, a produção de matéria seca no $1^{\circ}$. corte para o cultivar Colonião IZ-1 foi significativamente superior (teste Tukey $5 \%$ ) aos cultivares Vencedor, Centenário e Marandu, não havendo diferenças significativas entre as produções destes três últimos (Tabela 10).

No $2^{\circ}$. corte não foi observada resposta significativa de produção de matéria seca com o aumento das doses de corretivo para os cultivares Colonião IZ-1, Vencedor, Centenário e Marandu (Tabela 8). Houveram diferenças significativas $(p<0,05)$ entre as espécies, ou seja, Colonião IZ-1 e Vencedor produziram mais M.S. que o cultivar Centenário, independente do nível de calagem (Tabela 10).

A maior ou menor resposta das gramíneas à aplicação do calcário parece ser bastante variável em função do tipo de solo, do gênero, espécie e até cultivar. Pode-se encontrar na literatura grande número de trabalhos evidenciando o efeito positivo da calagem (LOTERO et al., 1971; COUTO et al., 1985; GOMIDE et al., 1986; BARCELOS \& SANZONOWICZ, 1987) no capim colonião, ou ausência de resposta (WERNER et al., 1967; WERNER et al., 1979), ou ainda, melhor desempenho de novos cultivares de Panicum em solos ácidos sem correção, quando comparados com cultivares conhecidos como o colonião Makuemi, Guiné, Coloninho e Tobiatã e $B$. brizantha cv. Marandu (JANK et al., 1987; HUTTON \& SOUSA, 1987; USBERTI FILHO et al., 1987; THOMAS \& LAPOINTE, 1989; CIAT, 1990). 
Tabela 8. Produçao de matéria seca (M.S.) na parte aérea no $1^{\circ}$. e $2^{\circ}$. corte e produção de matéria seca total (g/vaso) e $\mathrm{m}$ função dos niveis de calcário. nos cultivares Colonião L-1, Vencedor, Centenário e Marandu.

\begin{tabular}{lccc}
\hline $\begin{array}{l}\text { Niveis de } \\
\text { calcário }\end{array}$ & $\begin{array}{c}\text { M.S. parte aérea } \\
1^{\circ} \text { corte }\end{array}$ & $\begin{array}{c}\text { M.S. parte aérea } \\
2^{\circ} \text { corte }\end{array}$ & M.S. total \\
\hline & & & $29,70 \mathrm{a}$ \\
2 & $11,06 \mathrm{a}$ & $10,00 \mathrm{a}$ & 30,01 a \\
3 & $11.20 \mathrm{a}$ & $10,50 \mathrm{a}$ & 27,72 ab \\
4 & $9,66 \mathrm{~b}$ & $10,23 \mathrm{a}$ & $27.22 \mathrm{~b}$ \\
& $9,12 \mathrm{~b}$ & $10,40 \mathrm{a}$ & $*$ \\
Teste F & $* *$ & n.s. & $(0,83)^{* *}$ \\
Reg. linear & $(0,85)^{*}$ & n.s. & n.s. \\
Reg. quadrática & n.s. & n.s. & 7,25 \\
C.V. $\left({ }^{\circ}\right.$ \% $)$ & 8,71 & 9,64 & \\
\hline
\end{tabular}

Niveis de significància: ** $1 \%$; * $5 \%$; n.s. não significativo.

Os valores entre parênteses indicam o coeficiente de determinação $R^{2}$ para a equação.

Médias seguidas pela mesma letra, dentro de cada coluna, não difierem entre si pelo teste de Tukey $5 \%$.

Tabela 9. Produção de matéria seca (M.S.) da parte aérea ( $g / v a s o)$ no $1^{\circ}$. e $2^{\circ}$. corte, peso seco de raizes (g/vaso) e produção de matéria seca total ( $\mathrm{g} /$ vaso) em função dos niveis de calcário no capim-andropogon (médias de 4 repetições).

\begin{tabular}{|c|c|c|c|c|}
\hline \multirow{2}{*}{$\begin{array}{l}\text { Niveis } \\
\text { de } \\
\text { calcário }\end{array}$} & \multicolumn{2}{|c|}{ M.S. parte aérea } & \multirow{2}{*}{$\begin{array}{c}\text { Peso seco } \\
\text { de } \\
\text { raizes }\end{array}$} & \multirow{2}{*}{ M.S. total } \\
\hline & $1^{\circ}$. corte & $2^{\circ}$. corte & & \\
\hline 1 & 3,71 a & $11,50 \mathrm{a}$ & $12.89 \mathrm{a}$ & $28.11 \mathrm{a}$ \\
\hline 2 & $2.61 \mathrm{a}$ & $10,26 \mathrm{ab}$ & $10,16 \mathrm{ab}$ & $23,04 \mathrm{~b}$ \\
\hline 3 & $2.74 \mathrm{a}$ & $9,51 \mathrm{~b}$ & $9,68 \mathrm{~b}$ & $21,93 \mathrm{~b}$ \\
\hline 4 & $2,78 \mathrm{a}$ & $10,67 \mathrm{ab}$ & $10,98 \mathrm{ab}$ & $24,43 \mathrm{ab}$ \\
\hline Teste F & n.s. & * & * & $* *$ \\
\hline Reg. quadrática & n.s. & $(0,95)^{* *}$ & $(0,99)^{*}$ & $(0,99)^{* *}$ \\
\hline C.V. $(\%)$ & 23,38 & 6,65 & 12.93 & 7,95 \\
\hline
\end{tabular}

Niveis de significància: ${ }^{*} 1 \%$; ${ }^{*} 5 \%$; n.s. não significativo.

Os valores entre parênteses indicam o coeficiente de determinação $R^{2}$ para a equação.

Médias seguidas pela mesma letra. dentro de cada coluna, não difierem entre si pelo teste de Tukey $5 \%$. 

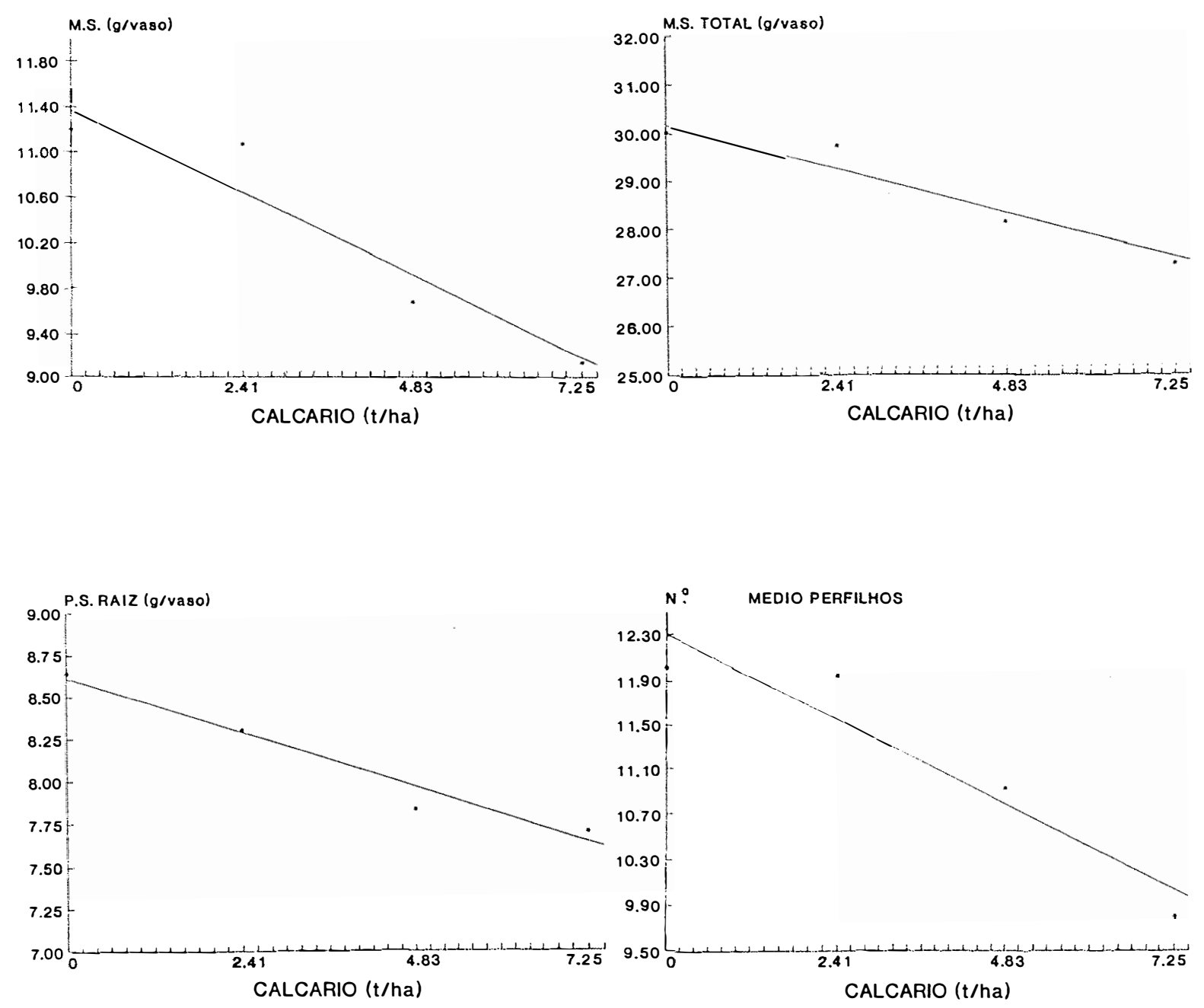

Figura 7. Efeito dos níveis de calcário na produção de M.S. parte aérea ( $1^{\circ}$. corte), produção de M.S. total, peso seco de raízes (P.S. raiz) e número médio de perfilhos dos cultivares Colonião IZ-1, Vencedor, Centenário e Marandu. 

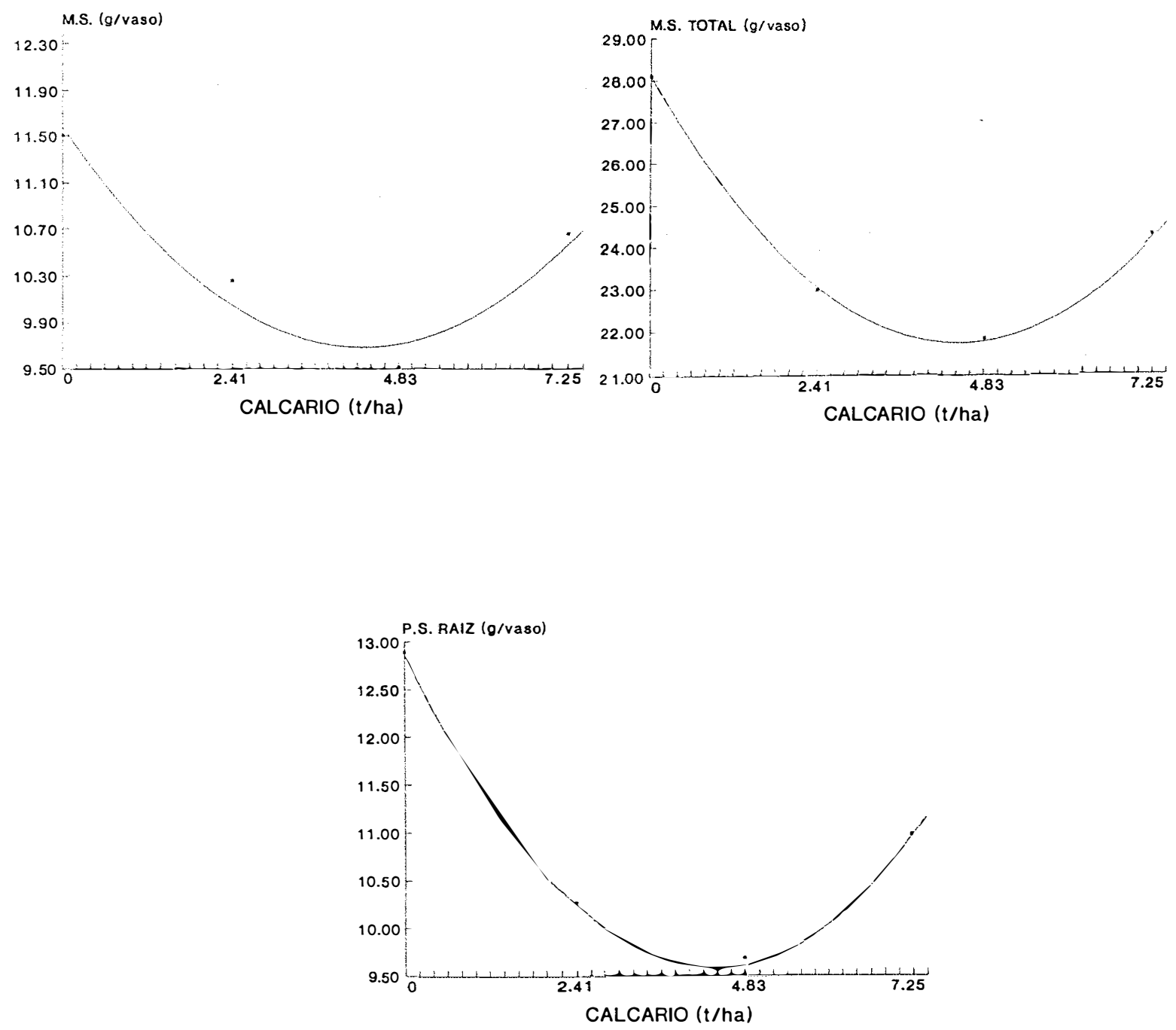

Figura 8. Efeito dos níveis de calcário na produção de M.S. parte aérea ( $1^{\circ}$. corte), produção de M.S. total, peso seco de raízes (P.S. raiz) para o capimandropogon. 
Também com relação às espécies do gênero Brachiaria trabalhos relatando maior ou menor efeito da calagem no aumento de M.S. são encontrados (LOTERO et al., 1971; SIQUEIRA et al., 1980; PEREIRA, 1987; SANZONOWICZ et al., 1987; CIAT, 1989). A ausência de resposta para o cultivar Marandu no $1^{\circ}$. corte foi observada por PREMAZZI (1991), trabalhando com níveis de saturação por bases.

Para o campim-andropogon, que foi analisado separadamente, não houve resposta significativa da produção de M.S. da parte aérea no $1^{\circ}$. corte com o aumento do nível de calcário (Tabela 9).

No $2^{\circ}$. corte observou-se diminuição da produção de forma quadrática de acordo com a equação $Y=11,577361-0,88326 X+0,103229 X^{2}$. Não foi verificada diferença de produção de MS (g/vaso) entre a não aplicação do corretivo (nível 1 com V\% $=21,55)$ e o nível mais alto de saturação por bases, nível 4 com V\%=69,05 (Tabela 9). O mesmo comportamento foi observado para a produção de matéria seca total, cuja equação de regressão foi $\mathrm{Y}=28,0901-2,8538 \mathrm{X}+0,32447 \mathrm{X}^{2}$ (Figura 8).

Resultados semelhantes são relatados por CIAT (1978), CIAT (1980), PAULINO et al. (1989) e COUTO et al. (1991).

\subsubsection{Produção de matéria seca de rázes - Peso seco de raízes}

Houve diferença significativa $(p<0,05)$ para os níveis estudados com relação ao peso seco de raízes. Porém tais diferenças não foram detectadas no teste de Tukey a 5\% (Tabela 11). A análise de regressão polinomial mostrou redução linear representada pela equação $Y=8,6132-0,13696 X$ (Figura 7). 
Tabela 10. Produção de matéria seca (M.S.) da parte aérea ( $\mathrm{g} / \mathrm{vaso})$ no $1^{\circ}$. e $2^{\circ}$. corte. produção de matéria seca total ( $\mathrm{g} / \mathrm{vaso}$ ), número médio de perfilhos/vaso, peso seco de raiz (g/vaso) e altura da haste principal (cm) entre os cultivares Colonião IZ-1, Vencedor, Centenário e Marandu (médias de 16 repetições).

\begin{tabular}{|c|c|c|c|c|c|c|c|}
\hline \multirow{2}{*}{ Cultivares } & \multicolumn{2}{|c|}{$\begin{array}{l}\text { Produção de } \\
\text { M.S. (g/vaso) }\end{array}$} & \multirow{2}{*}{$\begin{array}{l}\text { M.S. } \\
\text { total }\end{array}$} & \multicolumn{2}{|c|}{$\begin{array}{l}\mathrm{N}^{\circ} \text { médio de } \\
\text { perfilhos/vaso }\end{array}$} & \multirow{2}{*}{$\begin{array}{c}\text { Peso seco } \\
\text { de raiz } \\
\text { (g/vaso) }\end{array}$} & \multirow{2}{*}{$\begin{array}{l}\text { Altura do } \\
\text { haste prin- } \\
\text { cipal }(\mathrm{cm})^{1}\end{array}$} \\
\hline & $1^{\circ}$. corte & $2^{\circ}$. corte & & $1^{\circ}$. corte & $2^{\circ}$. corte & & \\
\hline Colonião IZ-1 & $11,83 \mathrm{a}$ & $10,90 \mathrm{a}$ & 30,18 a & $10,10 \mathrm{~b}$ & $12.69 \mathrm{~d}$ & $7,45 \mathrm{~b}$ & 27,41 a \\
\hline Vencedor & $9,70 \mathrm{~b}$ & 10,58 a & $28,80 \mathrm{bc}$ & 13,94 a & $17,69 \mathrm{~b}$ & $7,72 \mathrm{~b}$ & $21,75 \mathrm{~b}$ \\
\hline Centenário & $9,35 \mathrm{~b}$ & $9.51 \mathrm{~b}$ & $27,21 \mathrm{c}$ & $10,31 \mathrm{~b}$ & $14,87 \mathrm{c}$ & $7,96 \mathrm{~b}$ & $26,10 \mathrm{a}$ \\
\hline Marandu & $10,15 \mathrm{~b}$ & $10,14 \mathrm{ab}$ & $29,63 \mathrm{ab}$ & $10,37 \mathrm{~b}$ & 20,94 a & 9,34 a & 26,11 a \\
\hline Teste F & $* *$ & * & $* *$ & $* *$ & $* *$ & $* *$ & $* *$ \\
\hline C.V. (\%) & 8,71 & 9,64 & 7,25 & 14,54 & 11,34 & 12,68 & 8,61 \\
\hline
\end{tabular}

Níveis de significância: ** $1 \% ; * 5 \%$; n.s. não significativo.

Médias seguidas pela mesma letra. dentro de cada coluna, não difierem entre si pelo teste de Tukey $5 \%$.

${ }^{1}$ Dados referem-se à $3^{2}$. avaliação.

Tabela 11. Peso seco de raiz (g/vaso) e altura da haste principal (cm) dos cultivares Colonião LZ-1, Vencedor, Centenário e Marandu (médias de 16 repetições).

Niveis de calcário

Peso seco de raiz (g/vaso)

Altura da haste principal $(\mathrm{cm})^{1}$

\begin{tabular}{lcc}
\hline & $8,64 \mathrm{a}$ & $25,50 \mathrm{a}$ \\
2 & $8,30 \mathrm{a}$ & $25,12 \mathrm{a}$ \\
3 & $7,83 \mathrm{a}$ & $24,87 \mathrm{a}$ \\
4 & $7,70 \mathrm{a}$ & $25,90 \mathrm{a}$ \\
& & \\
Teste F & $*$ & n.s. \\
Regressão linear & $(0,96)^{* *}$ & n.s. \\
C.V. (\%) & 12,68 & 8,65 \\
& & \\
\hline
\end{tabular}

Níveis de significância: ** $1 \% ; * 5 \%$; n.s. não significativo.

Médias seguidas pela mesma letra, dentro de cada coluna, não diferem entre si pelo teste de Tukey $5 \%$.

Os valores entre parênteses indicam o coeficiente de determinação $R^{2}$ para a equação.

1 Dados referem-se à $3^{2}$, avaliação. 
O cultivar Marandu produziu significativamente $(\mathrm{p}<0,01)$ maior peso seco de raízes que os cultivares IZ-1, Vencedor e Centenário (Tabela 10).

O capim-andropogon produziu significativamente menor peso seco de raízes (9,68 g/vaso), quando o $\mathrm{V} \%$ foi de 57,12 (nível 3) contra 12,89 g/vaso no nível 1 (zero de calcário) onde o $\mathrm{V} \%$ foi de 21,55 (Tabela 9). O peso seco de raízes no nível mais alto de calagem onde $\mathrm{V} \%=69,05$ foi igual à testemunha sem calcário (Tukey $5 \%$ ), segundo a equação $\mathrm{Y}=12,8637-2,8538 \mathrm{X}+0,17256 \mathrm{X}^{2}$ (Figura 8).

Esta espécie não aumentou seu peso seco radicular com aumento da correção do solo para as condições do experimento. Resultados opostos foram obtidos por BARCELLOS \& SANZONOWICZ (1987).

\subsubsection{Número médio de perfilhos/vaso}

Houve efeito significativo $(\mathrm{p}<0,05)$ dos níveis de calcário no perfilhamento dos cultivares IZ-1, Vencedor, Centenário e Marandu no primeiro corte (Tabela 13). As espécies diminuiram o perfilhamento de forma linear $\mathrm{Y}=12,3057$ 0,3129X (Figura 7) no nível de saturação mais elevado de saturação por bases $(\mathrm{V} \%=68,8)$, não se encontrando diferenças significativas nos três níveis iniciais de saturação por bases. Resultados semelhantes foram encontrados por WERNER et al. (1967). Por outro lado, aumento no número médio de perfilhos/planta/vaso até $37 \%$ de saturação por bases foi encontrado por PREMAZZI (1991), em capim-colonião. Estes cultivares não diferiram entre si com relação ao número de perfilhos/vaso, com exceção do cultivar Vencedor cuja produção de perfilhos foi maior que as demais $(\mathrm{p}<0,01 \%)$ (Tabela 10$)$. 
No $2^{\circ}$. corte ocorreram diferenças altamente significativas entre os quatro cultivares, conforme pode-se verificar pelo teste de Tukey $5 \%$ (Tabela 10), cuja ordem decrescente de número total médio de perfilhos/vaso foi Marandu, Vencedor, Centenário e Colonião IZ-1.

Para o capim-andropogon não houve influência dos níveis de calcário empregados no perfilhamento nas avaliações realizadas no $1^{\circ}$. e $2^{\circ}$. cortes (Tabela 12).

\subsubsection{Altura da Haste Principal}

Não houve efeito significativo para este parâmetro em função da elevação da saturação por bases do solo, nas três avaliações efetuadas para os cultivares Colonião IZ-1, Vencedor, Centenário e Brizantha Marandu (Tabela 11).

Entretanto, ocorreram efeitos altamente significativos $(p<0,01)$ para diferenças entre os cultivares. O cultivar Vencedor apresentou menor altura da haste principal que os outros três capins. Os outros cultivares não diferiram entre si pelo teste de Tukey a $5 \%$ (Tabela 10$)$.

Para o capim-andropogon não houve diferença significativa na altura da haste principal com o aumento das doses de calcário, conforme mostra a Tabela 12. 
Tabela 12. Número médio de perfilhosivaso e altura da haste principal (cm) do capim-andropogon (médias de 4 repetiçōes).

\begin{tabular}{|c|c|c|c|}
\hline \multirow{2}{*}{$\begin{array}{l}\text { Níveis } \\
\text { de } \\
\text { calcário }\end{array}$} & \multicolumn{2}{|c|}{$\begin{array}{l}N^{\circ} \text {. médio de } \\
\text { perfilhosivaso }\end{array}$} & \multirow{2}{*}{$\begin{array}{c}\text { Altura da haste } \\
\text { principal }^{1}\end{array}$} \\
\hline & $1^{\circ}$. corte & $2^{\circ}$. corte & \\
\hline 1 & $13,50 \mathrm{a}$ & $54,50 \mathrm{a}$ & $17,33 \mathrm{a}$ \\
\hline 2 & $12,00 \mathrm{a}$ & $47,25 \mathrm{a}$ & $18,17 \mathrm{a}$ \\
\hline 3 & $11,25 \mathrm{a}$ & $48,00 \mathrm{a}$ & $14,00 \mathrm{a}$ \\
\hline 4 & $10,75 \mathrm{a}$ & $54,25 \mathrm{a}$ & $17,33 \mathrm{a}$ \\
\hline Teste F & n.s. & n.s. & n.s. \\
\hline Regressão linear & n.s. & n.s. & n.s. \\
\hline Regressão quadrática & n.s. & n.s. & n.s. \\
\hline C.V. $(\%)$ & 25,76 & 21,43 & 12,86 \\
\hline
\end{tabular}

Níveis de significància: ** $1 \% ; * 5 \%$; n.s. não significativo.

Médias seguidas pela mesma letra, dentro de cada coluna, não difierem entre si pelo teste de Tukey $5 \%$.

Os valores entre parênteses indicam o coeficiente de determinação $R^{2}$ para a equação.

${ }^{1}$ Dados referem-se à $3^{2}$. avaliação.

Tabela 13. Número médio de perfilhos/vaso dos cultivares Colonião IZ-1, Vencedor, Centenário e Marandu no $1^{\circ}$. e $2^{\circ}$. corte (médias de 16 repetiçōes).

\begin{tabular}{lcc} 
Niveis de calcário & $1^{\circ}$. corte $^{l}$ & $2^{\circ}$. corte \\
\hline & & $16,81 \mathrm{a}$ \\
2 & $12,00 \mathrm{a}$ & $16,62 \mathrm{a}$ \\
3 & $11,94 \mathrm{a}$ & $16,44 \mathrm{a}$ \\
4 & $10,94 \mathrm{ab}$ & $16,31 \mathrm{a}$ \\
& $9,81 \mathrm{~b}$ & n.s. \\
Teste F & $* *$ & n.s. \\
Regressão linear & $(0,90)^{* *}$ & 11,35 \\
C.V. (\%) & 14,54 &
\end{tabular}

Níveis de significància: ** $1 \% ; * 5 \%$; n.s. não significativo.

Médias seguidas pela mesma letra, dentro de cada coluna, não difierem entre si pelo teste de Tukey $5 \%$.

Os valores entre parênteses indicam o coeficiente de determinação $R^{2}$ para a equação.

${ }^{1}$ Dados referem-se à $3^{2}$. avaliação. 


\subsubsection{Composição Mineral - Macronutrientes}

Os teores de macro e micronutrientes da parte aérea e nitrogênio nas raízes estão, em geral, dentro dos níveis relatados pela literatura, para o estádio de crescimento no qual as plantas foram cortadas e para o nível de adubação empregado, com exceção do $\mathrm{Fe}$, que apresentou-se um pouco abaixo da média (GALLO et al., 1974; FALADE, 1975; SOUZA et al., 1989 e PAULINO et al., 1989).

\section{2 .5.1. Nitrogênio}

$\mathrm{Na}$ Tabela 14 observa-se que houve elevação altamente significativa na percentagem de $\mathrm{N}$ apenas para o nível mais alto de calcário, com $68,8 \%$ de saturação por bases, para os cultivares Colonião IZ-1, Vencedor, Centenário e Marandu no $1^{\circ}$. corte, representada pela equação $Y=1,6381-0,02178 X+0,01108 X^{2}$ (Figura 10). Como houve uma diminuição da produção de M.S. destes cultivares com o aumento do nível de calcário, observa-se um efeito de "concentração" deste nutriente nos níveis mais altos de saturação por bases.

No $2^{\circ}$. corte não foram observadas variações significativas na percentagem de nitrogênio com os tratamentos empregados (Tabela 14). Porém a análise de regressão polinomial mostrou comportamento quadrático representado pela equação $\mathrm{Y}$ $=1,6087-0,0594 X+0,00705 X^{2}($ Figura 12). 
A elevação da $\mathrm{V} \%$ através da calagem não alterou a percentagem de $\mathrm{N}$ na M.S. do capim-andropogon no $1^{\circ}$. e $2^{\circ}$. corte (Tabela 15). PAULINO et al. (1989), trabalhando com calagem e doses de $\mathrm{P}$ observaram efeito positivo da aplicação de calcário no teor de $\mathrm{N}$ da parte aérea dessa gramínea com a dose mais elevada de $\mathrm{P}$ no $1^{\circ}$. corte e em ambas doses no $2^{\circ}$. corte, explicado pela concentração de $\mathrm{N}$ decorrente da menor produção de M.S., nos tratamentos com calagem.

\subsubsection{Quantidade Total de Nitrogênio na Parte Aérea (QTN)}

A elevação da saturação por bases através da calagem não alterou significativamente a quantitade total de nitrogênio nos cultivares estudados em ambos os cortes (Tabela 16).

Observaram-se diferenças significativas $(\mathrm{p}<0,01)$ entre os cultivares quanto ao QTN (Tabela 17). No $1^{\circ}$. corte capim Colonião IZ-1 e Marandu produziram maior QTN. Os cultivares Vencedor, Centenário não diferiram entre si. No $2^{\circ}$. corte, o Colonião IZ-1 produziu maior QTN, enquanto Vencedor, Centenário e Marandu não diferiram entre si.

PAULINO (1990) relatou que a QTN foi mais elevada para o cultivar Colonião IZ-1 no $3^{\circ}$. e $4^{\circ}$. cortes em presença de calagem.

Aumento linear de QTN com aumento do nível de saturação por bases em Brachiaria brizantha cv. marandu no $2^{\circ}$. corte e decréscimo inicial seguido de aumento para o capim Colonião IZ-1, no $1^{\circ}$. corte foram observados por PREMAZZI (1991) 
Tabela 14. Percentagem de nitrogênio (N) na M.S. d a parte aérea dos cultivares Colonião IZ-1, Vencedor, Centenário e Marandu no $1^{\circ}$. e $2^{\circ}$. corte (médias de 16 repetiçòes)

Niveis de calcário

$1^{\circ}$. corte

$2^{\circ}$. corte

\begin{tabular}{lcc}
\hline 1 & $1,64 \mathrm{~b}$ & $1,61 \mathrm{a}$ \\
2 & $1,63 \mathrm{~b}$ & $1,50 \mathrm{a}$ \\
3 & $1,81 \mathrm{~b}$ & $1,49 \mathrm{a}$ \\
4 & $2,05 \mathrm{a}$ & $1,54 \mathrm{a}$ \\
& & \\
Teste F & $* *$ & n.s. \\
Regressão quadrática & $(0,99)^{*}$ & $(0,99)^{*}$ \\
C.V. (\%) & 11.53 & 9,78 \\
\end{tabular}

Níveis de significància: $* * 1 \% ; * 5 \%$; n.s. não significativo.

Médias seguidas pela mesma letra, dentro de cada coluna, não difierem entre si pelo teste de Tukey $5 \%$.

Os valores entre parênteses indicam o coeficiente de determinação $R^{2}$ para a equação.

Tabela 15. Percentagem de nitrogênio $(\mathrm{N})$, fósforo $(\mathrm{P})$ e potássio $(\mathrm{K})$ na matéria seca (M.S.) da parte aérea do capim-andropogon no $1^{\circ}$. e $2^{\circ}$. corte (médias de 4 repetições).

\begin{tabular}{|c|c|c|c|c|c|c|}
\hline \multirow{2}{*}{$\begin{array}{l}\text { Niveis } \\
\text { de } \\
\text { calcário }\end{array}$} & \multicolumn{3}{|c|}{$1^{\circ}$. corte } & \multicolumn{3}{|c|}{$2^{\circ}$. corte } \\
\hline & $\mathbf{N}$ & $P$ & $\mathrm{~K}$ & $\mathbf{N}$ & $P$ & $\mathrm{~K}$ \\
\hline 1 & $1,82 \mathrm{a}$ & $0,16 \mathrm{a}$ & $2,19 \mathrm{a}$ & $1,35 \mathrm{a}$ & $0,11 \mathrm{a}$ & $1.72 \mathrm{a}$ \\
\hline 2 & $1,94 \mathrm{a}$ & $0,14 \mathrm{a}$ & $1,87 \mathrm{a}$ & $1,48 \mathrm{a}$ & $0,12 \mathrm{a}$ & $2,22 \mathrm{a}$ \\
\hline 3 & $1,79 \mathrm{a}$ & $0,15 \mathrm{a}$ & $2,08 \mathrm{a}$ & $1,41 \mathrm{a}$ & $0,12 \mathrm{a}$ & $2,02 \mathrm{a}$ \\
\hline 4 & $2.10 \mathrm{a}$ & $0,17 \mathrm{a}$ & $2.25 \mathrm{a}$ & $1,52 \mathrm{a}$ & $0,12 \mathrm{a}$ & $1,96 \mathrm{a}$ \\
\hline Teste F & n.s. & n.s. & n.s. & n.s. & n.s. & n.s. \\
\hline Reg. linear & n.s. & n.s. & n.s. & n.s. & n.s. & n.s. \\
\hline Reg. quadrática & n.s. & n.s. & n.s. & n.s. & n.s. & n.s. \\
\hline C.V. (\%) & 11,27 & 14,27 & 13.39 & 6,42 & 11.66 & 14,23 \\
\hline
\end{tabular}

Níveis de significància: ** $1 \% ; * 5 \%$; n.s. não significativo.

Médias seguidas pela mesma letra, dentro de cada coluna, não diferem entre si pelo teste de Tukey $5 \%$. 


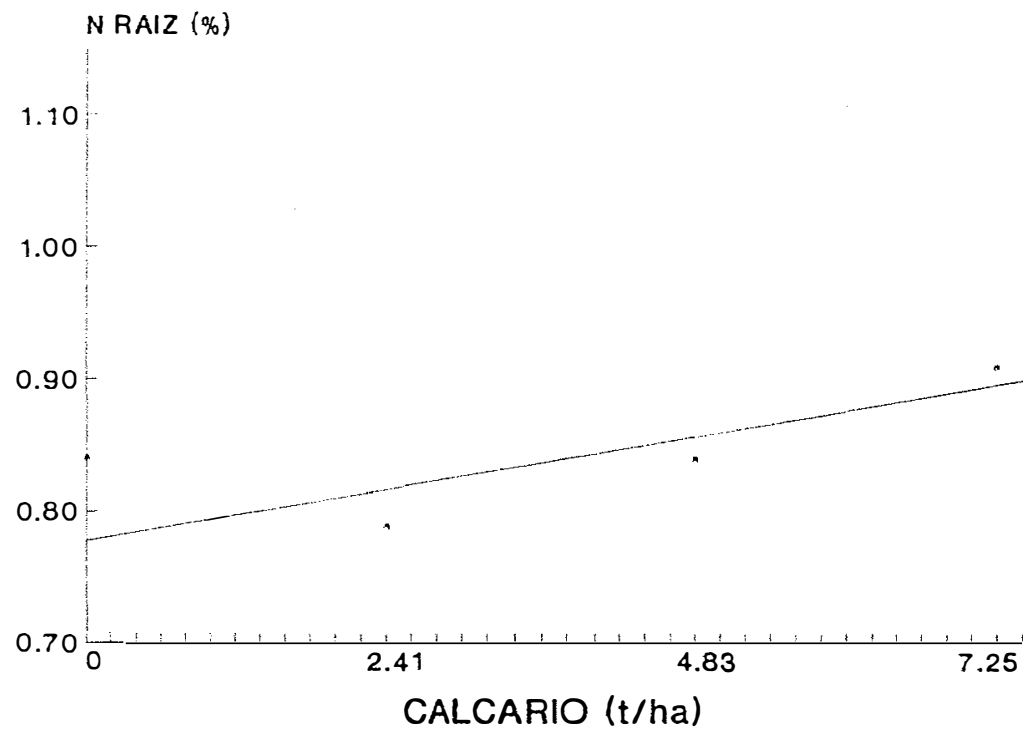

Figura 9. Efeito dos níveis de calcário na percentagem de nitrogênio na matéria seca das raízes ( $\mathrm{N}$ raiz) dos cultivares Colonião IZ-1, Vencedor, Centenário e Marandu. 

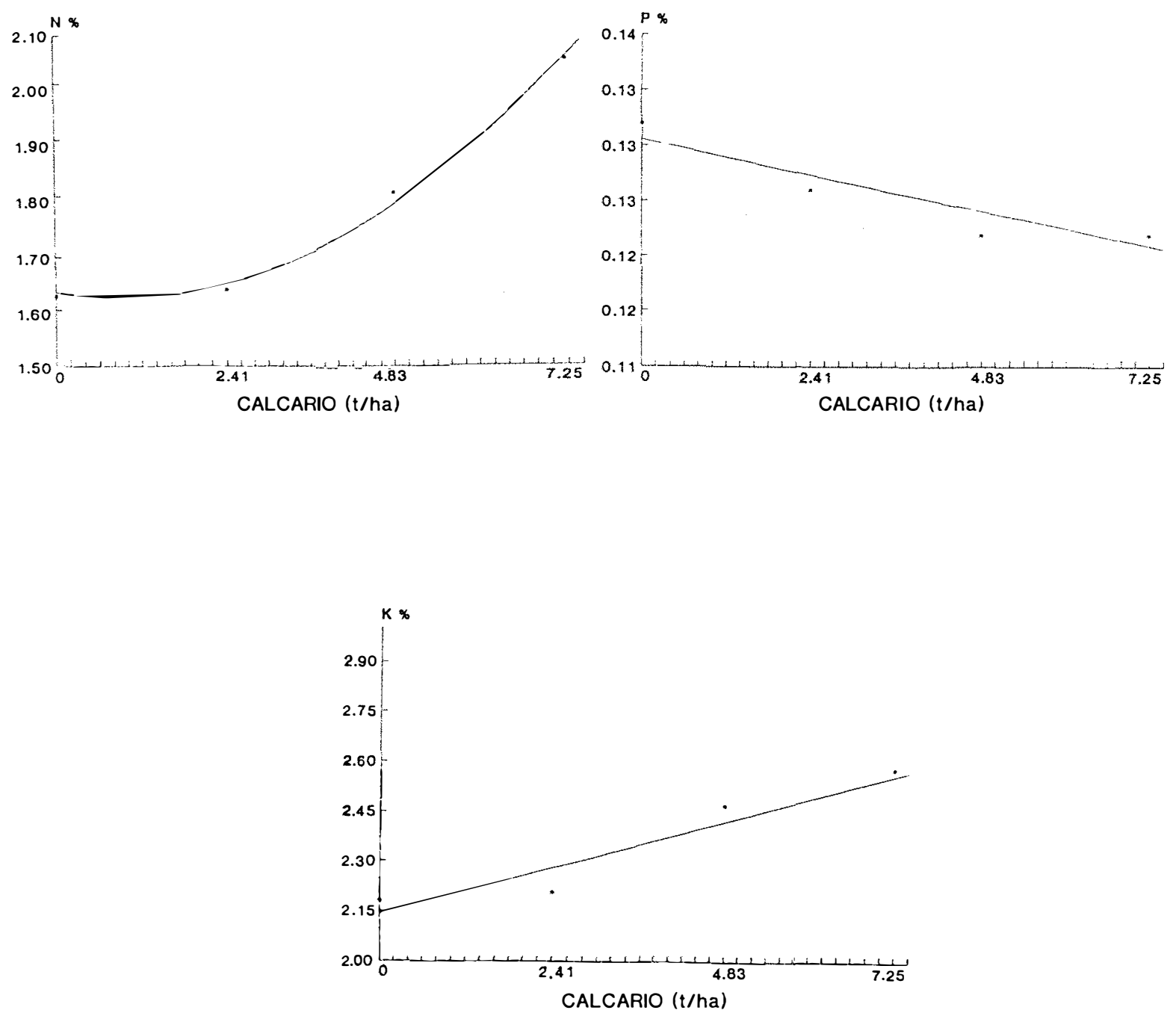

Figura 10. Efeito dos níveis de calcário na percentagem de $\mathrm{N}, \mathrm{P}$ e $\mathrm{K}$ na matéria seca da parte aérea dos cultivares Colonião IZ-1, Vencedor, Centenáraio e Marandu no $1^{\circ}$. corte. 
Tabela 16. Quantidade total de nitrogènio QTN (g/vaso) na M.S. da parte aérea para os cultivares Colonião IZ-1, Vencedor, Centenário e Marandu. $1^{\circ}$. e $2^{\circ}$. corte (médias de 16 repetiçōes).

\begin{tabular}{lcc}
\hline Niveis de calcário & QTN $1^{\circ}$. corte & QTN 2 . corte \\
\hline & $0,18 \mathrm{a}$ & $0,16 \mathrm{a}$ \\
1 & $0,18 \mathrm{a}$ & $0,16 \mathrm{a}$ \\
3 & $0,17 \mathrm{a}$ & $0,15 \mathrm{a}$ \\
4 & $0,19 \mathrm{a}$ & $0,16 \mathrm{a}$ \\
& & \\
Teste F & n.s. & n.s. \\
Regressão linear & n.s. & n.s. \\
Regressão quadrática & n.s. & n.s. \\
C..$^{\circ}\left({ }^{\circ} \%\right)$ & 11,62 & 11.99 \\
\hline
\end{tabular}

Niveis de significància: ** $1 \%: * 5 \%$; n.s. não significativo.

Médias seguidas pela mesma letra, dentro de cada coluna. não diferem entre si pelo teste de Tukey $5 \%$.

Tabela 17. Quantidade total de nitrogènio QTN (g/vaso) na M.S. da parte aérea entre os cultivares Colonião IZ-1, Vencedor, Centenário e $M$ arandu $1^{\circ}$. e $2^{\circ}$. corte (médias de 16 repetiçōes).

Quantidade total de nitrogènio na M.S.

QTN (g/vaso)

Cultivar

\begin{tabular}{cc}
\hline & \\
$1^{\circ}$. corte & $2^{\circ}$. corte \\
& \\
$0.19 \mathrm{a}$ & $0,17 \mathrm{a}$ \\
$0,17 \mathrm{~b}$ & $0,15 \mathrm{~b}$ \\
$0,17 \mathrm{~b}$ & $0,15 \mathrm{~b}$ \\
$0,19 \mathrm{a}$ & $0,15 \mathrm{~b}$ \\
& \\
$* *$ & $* *$ \\
n.s. & n.s. \\
11.62 & 11,99
\end{tabular}

Niveis de significància: ** $1 \%$; $* 5 \%$; n.s. não significativo.

Médias seguidas pela mesma letra, dentro de cada coluna, não difierem entre si pelo teste de Tukey $5 \%$. 
A elevação da saturacão por bases através da calagem não alterou a quantitade total de nitrogênio no $1^{\mathrm{a}}$. e $2^{\circ}$. cortes para o capim-andropogon (Tabela 18).

PAULINO et al. (1989), trabalhando com este capim notaram que a ausência de calagem possibilitou maiores rendimentos de QTN no $1^{\circ}$. corte. Não foram observadas diferenças significativas na QTN com ausência ou presença de calagem no $2^{\circ}$. corte.

\subsubsection{Nitrogênio nas raízes}

O efeito dos níveis de calcário e as diferenças entre os cultivares com relação à percentagem de $\mathrm{N}$ nas raízes foram altamente significativas $(\mathrm{p}<0,01)$. Significativa também foi a interação dos fatores níveis e cultivares, com comportamentos diferentes dentro de cada nível de calagem (Tabelas 19 e 20).

Observou-se aumento linear na percentagem de $\mathrm{N}$ nas raízes a partir de $\mathrm{V} \%=57,167$ para o cultivar Vencedor representado pela equação $\mathrm{Y}=0,8373+$ $0,02628 \mathrm{X}\left(\mathrm{R}^{2}=0,90\right)$ e a partir de $\mathrm{V} \%=69,55$ para o Centenário, representado pela equação $\mathrm{Y}=0,7796+0,0313 \mathrm{X}\left(\mathrm{R}^{2}=0,84\right)$. Os cultivares Colonião IZ-1 e Marandu não alteraram o teor de $\mathrm{N}$ nas raízes com o aumento do nível de calcário (Tabela 19). Porém, a regressão polinomial para a média dos 4 cultivares foi representado pela equação $\mathrm{Y}=$ $0,7783+0,0165 \mathrm{X}$ como mostra a Figura 9.

Com exceção dos níveis 1 e 2 do corretivo empregado, os cultivares de Panicum apresentaram maior percentagem de $\mathrm{N}$ radicular que a Braquiaria, porém esta obteve significativamente maior produção de M.S. de raízes (Tabela 20). 
Tabela 18. Quantidade total de nitrogênio QTN (g/vaso) na M.S. da parte aérea do capim-andropogon no $1^{\circ}$. e $2^{\circ}$. corte (médias de 4 repetiçòes).

Quantidade total de nitrogênio na M.S.

QTN (g/vaso)

Cultivar

$1^{\circ}$. corte $\quad 2^{\circ}$. corte

\begin{tabular}{lcl}
\hline & & \\
1 & $0,06 \mathrm{a}$ & $0,15 \mathrm{a}$ \\
2 & $0,05 \mathrm{a}$ & $0,15 \mathrm{a}$ \\
3 & $0,05 \mathrm{a}$ & $0,13 \mathrm{a}$ \\
4 & $0,05 \mathrm{a}$ & $0,16 \mathrm{a}$ \\
Teste F & & \\
Regressão linear & n.s. & n.s. \\
C.V. (\%) & n.s. & n.s. \\
& 16,60 & 9,53
\end{tabular}

Niveis de significância: ** $1 \%$ : * 5\%: n.s. não significativo.

Médias seguidas pela mesma letra, dentro de cada coluna, não diferem entre si pelo teste de Tukey $5 \%$.

Os valores entre parênteses indicam o coeficiente de determinação $R^{2}$ para a equação.

Tabela 19. Percentagem de nitrogênio na matéria seca das raizes (N raizes) dos cultivares Colonião IZ-1, Vencedor, Centenário, Marandu e Andropogon (médias de 4 repetições).

\begin{tabular}{|c|c|c|c|c|c|c|}
\hline \multirow{2}{*}{$\begin{array}{l}\text { Níveis } \\
\text { de } \\
\text { calcário }\end{array}$} & \multicolumn{6}{|c|}{$\mathrm{N}$ raizes } \\
\hline & $\begin{array}{l}\text { Médias de } \\
16 \text { repet. }\end{array}$ & $\begin{array}{c}\text { Colonião } \\
\text { IZ-1 }\end{array}$ & Vencedor & Centenário & Marandu & Andropogon \\
\hline 1 & $0,80 \mathrm{~b}$ & $0,85 \mathrm{a}$ & $0,86 \mathrm{~b}$ & $0,81 \mathrm{~b}$ & 0,67 a & $0,87 \mathrm{a}$ \\
\hline 2 & $0.79 \mathrm{~b}$ & $0,79 \mathrm{a}$ & $0,86 \mathrm{~b}$ & $0,84 \mathrm{~b}$ & $0,68 \mathrm{a}$ & $0,95 \mathrm{a}$ \\
\hline 3 & $0,84 \mathrm{ab}$ & $0.78 \mathrm{a}$ & $0,96 \mathrm{ab}$ & $0,88 \mathrm{~b}$ & $0.64 \mathrm{a}$ & $0.91 \mathrm{a}$ \\
\hline 4 & 0,91 a & 0,89 a & $1,04 \mathrm{a}$ & $1,05 \mathrm{a}$ & $0,67 \mathrm{a}$ & $0,97 \mathrm{a}$ \\
\hline Teste F & ** & - & - & . & - & n.s. \\
\hline Reg. linear & $(0,85)^{* *}$ & n.s. & $(0,90)^{* *}$ & $(0,84)^{* *}$ & n.s. & n.s. \\
\hline C.V. $(\%)$ & 8,89 & - & - & - & . & 6,59 \\
\hline
\end{tabular}

Teste $\mathrm{F}$ para a interação niveis $\mathrm{x}$ cultivares: *

Niveis de significância: ${ }^{* *} 1 \% ; *$ \% 5 ; n.s. não significativo.

Médias seguidas pela mesma letra, dentro de cada coluna, não difierem entre si pelo teste de Tukey $5 \%$.

Os valores entre parênteses indicam o coeficiente de determinação $R^{2}$ para a equação. 


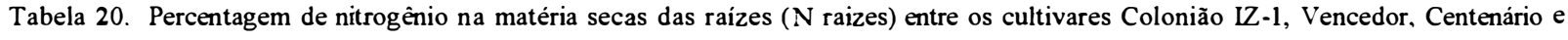
Marandu nos níveis de calcário ao $2^{\circ}$. corte ${ }^{1}$ (médias de 4 repetições).

$\mathrm{N}$ raizes

\begin{tabular}{lccccc} 
Cultivares & $\begin{array}{c}\text { Médias de } \\
16 \text { repet. }\end{array}$ & 1 & 2 & 3 & 4 \\
\hline & & & & & \\
Colonião IZ-1 & $0,86 \mathrm{~b}$ & $0,85 \mathrm{a}$ & $0.79 \mathrm{ab}$ & $0,89 \mathrm{a}$ & $0,89 \mathrm{~b}$ \\
Vencedor & $0,93 \mathrm{a}$ & $0,86 \mathrm{a}$ & $0,86 \mathrm{a}$ & $0,96 \mathrm{a}$ & $1,04 \mathrm{a}$ \\
Centenário & $0,89 \mathrm{ab}$ & $0,81 \mathrm{ab}$ & $0,84 \mathrm{a}$ & $0,88 \mathrm{a}$ & $1,05 \mathrm{a}$ \\
Marandu & $067 \mathrm{c}$ & $0,67 \mathrm{~b}$ & $0,68 \mathrm{~b}$ & $0,64 \mathrm{~b}$ & $0,67 \mathrm{c}$ \\
& & & & - & - \\
Teste F & $* *$ & - & - & - & - \\
C.V. $(\%)$ & 8,89 & - & - & - \\
\hline
\end{tabular}

Teste $\mathrm{F}$ para a interação níveis $\mathrm{x}$ cultivares: *

Níveis de significância: ** $1 \%$; * 5\%; n.s. não significativo.

Médias seguidas pela mesma letra, dentro de cada coluna, não difierem entre si pelo teste de Tukey $5 \%$.

${ }^{1}$ Níveis de calagem correspondem à V\% do solo no $2^{\circ}$. corte (Tabela 10 ).

Tabela 21. Percentagem de fösforo (P) na M.S. e potássio (K) na M.S. da parte aérea dos cultivares Colonião IZ-1, Vencedor, Centenário e Marandu no $1^{\circ}$. e $2^{\circ}$. corte (médias de 16 repetições).

\begin{tabular}{|c|c|c|c|c|}
\hline \multirow{2}{*}{$\begin{array}{l}\text { Níveis } \\
\text { de } \\
\text { calcário }\end{array}$} & \multicolumn{2}{|c|}{$1^{\circ}$. corte } & \multicolumn{2}{|c|}{$2^{\circ}$. corte } \\
\hline & $\mathrm{P}$ & $\mathrm{K}$ & $P$ & $\mathrm{~K}^{1}$ \\
\hline 1 & $0,13 \mathrm{a}$ & $2,18 \mathrm{~b}$ & $0,13 \mathrm{a}$ & $1,54 \mathrm{~b}$ \\
\hline 2 & $0,13 \mathrm{ab}$ & $2,21 \mathrm{~b}$ & $0,13 \mathrm{a}$ & $1,52 \mathrm{~b}$ \\
\hline 3 & $0,12 \mathrm{ab}$ & $2,47 \mathrm{a}$ & $0,13 \mathrm{a}$ & $1,63 \mathrm{a}$ \\
\hline 4 & $0,12 \mathrm{~b}$ & $2,58 \mathrm{a}$ & $0,13 \mathrm{a}$ & $1,64 \mathrm{a}$ \\
\hline Teste F & * & ** & n.s. & * \\
\hline Regressão linear & $(0,95)^{* *}$ & $(0,93)^{* *}$ & n.s. & $(0,75)^{* *}$ \\
\hline C.V. $(\%)$ & 7,25 & 7,52 & 7,54 & 8,20 \\
\hline
\end{tabular}

Niveis de significância: ${ }^{* *} 1 \% ;{ }^{*} 5 \%$; n.s. não significativo.

Médias seguidas pela mesma letra, dentro de cada coluna, não diferem entre si pelo teste de Tukey $5 \%$.

Os valores entre parênteses indicam o coeficiente de determinação $R^{2}$ para a equação.

${ }^{1}$ Teste de Duncan $5 \%$. 
Para o capim-andropogon não se observou diferença significativa na percentagem de $\mathrm{N}$ nas raízes com os tratamentos utilizados (Tabela 19).

A forma como foi conduzido o experimento não permite avaliar se a produção de M.S., percentagem de $\mathrm{N}$ e quantidade total de nitrogênio nas raízes do Andropogon foram significativamente maiores que as demais cultivares.

\subsubsection{Fósforo}

No $1^{\circ}$. corte (Tabela 21 ), observou-se diminuição do teor de fósforo na M.S. entre o primeiro e último nível do corretivo para os cultivares Colonião IZ-1, Vencedor, Centenário e Marandu, representado pela equação $\mathrm{Y}=0,1306-0,00132 \mathrm{X}$ (Figura 10). Como houve redução de produção de M.S. ( $1^{\circ}$. corte) nos níveis mais altos de V\% pode-se observar redução real no teor desse nutriente nas plantas. Não houve efeito dos tratamentos sobre este nutriente no $2^{\circ}$. corte. Também não foram observados efeitos positivos da calagem no teor de P da M.S. do capim-colonião no trabalho de WERNER et al. (1979).

A percentagem de $\mathrm{P}$ na M.S. não diferiu entre os cultivares, com exceção do Marandu o qual apresentou maior teor deste nutriente $(p>0,01)$ com média de 0,14\% de P na M.S. (Tabela 27). 
Estes teores de P estão um pouco abaixo dos encontrados por SOUZA et al. (1989), de $0,17 \%$ e $0,26 \%$ para $B$. humidicola e $B$. nuziziensis, respectivamente aos 28 dias de idade, em experimento de campo com adubação de $60 \mathrm{~kg}$ de $\mathrm{P}_{2} \mathrm{O}_{5} /$ ha na forma de superfosfato simples, em Latossolo Vermelho distrófico. Estes teores porém se encontram dentro da faixa observada por MEIRELLES et al. (1988) para o capim-colonião IZ-1, com a adubação de $100 \mathrm{~kg}$ de $\mathrm{P}_{2} \mathrm{O}_{5} /$ ha, cortado aos 35 dias após a emergência $\left(1^{\circ}\right.$. corte), e 40 dias após o início da rebrota ( $2^{\circ}$. corte), levando-se em conta a média das percentagens de P na M.S. de folhas velhas $(0,12 \%)$, folhas novas $(0,14 \%)$, colmo (\%; $3 \%)$ e brotos $(0,22 \%)$

Devido ao tipo de solo utilizado neste trabalho a capacidade de fixação de $\mathrm{P}$ pode ser causa do baixo teor deste elemento nas plantas, a despeito da boa adubação utilizada $\left(110 \mathrm{~kg}\right.$ de $\left.\mathrm{P}_{2} \mathrm{O}_{5} / \mathrm{ha}\right)$.

Na Tabela 15 são apresentadas as percentagens de P na M.S. para o capim-andropogon. Os níveis de calcário aplicados não alteraram a percentagem de $\mathrm{P}$ na M.S. do capim-andropogon no $1^{\circ}$. e $2^{\circ}$ cortes.

Já PAULINO et al. (1989) observaram aumento no teor deste nutriente com a calagem em ambos os cortes.

As percentagens de $\mathrm{P}$ na M.S. foram semelhantes as encontradas por FALADE (1975) e BERROTERÁN (1989). 


\subsubsection{Potássio}

Os níveis de calcário resultaram em aumento de K na M.S. $(p<0,01)$ dos cultivares Colonião IZ-1, Vencedor, Centenário e Marandu a partir de V\%=57,03 no $1^{\circ}$. corte, representado pela equação $\mathrm{Y}=2,1452+0,0598 \mathrm{X}$ (Tabela 21 e Figura 10, respectivamente). Os cultivares Vencedor e Centenário apresentaram suas percentagens de K na M.S. significativamente $(\mathrm{p}<0,01)$ mais elevadas que os cultivares IZ-1 e Marandu (Tukey 5\%), podendo ter ocorrido efeito de "concentração" deste nutriente na M.S., já que houve diminuição da produção de M.S. nos níveis mais elevados de saturação por bases.

No $2^{\circ}$. corte houve efeito dos níveis de calcário $(p<0,05)$ na elevação de K na M.S., com aumentos a partir de V\%=57,16 (Tabela 21), porém tal elevação só foi detectada pelo teste de Duncan $5 \%$. Este aumento foi representado pela equação linear $\mathrm{Y}=1,5206+0,0176 \mathrm{X}$ (Figura 12).

O cultivar Centenário apresentou teores mais elevados (Tukey 5\%) que os capins Colonião IZ-1 e Marandu, como mostra a Tabela 27.

WERNER et al. (1979) e PAULINO (1990) não observaram aumentos significativos no teor de $\mathrm{K}$ com o aumento do nível de calcário em capim-colonião. Já PREMAZZI (1991) observou efeito de "diluição" deste nutriente no $1^{\circ}$. e $2^{\circ}$. cortes, quando aumentos de M.S. foram seguidos por diminuições no teor de $\mathrm{K}$, com a elevação no nível de saturação por bases. Diminuição no teor de potássio com o aumento do nível de calcário foi observado por JONES \& FREITAS (1970), trabalhando com quatro leguminosas forrageiras e por MONTEIRO \& CARRIEL (1987), para capim-colonião com aplicação de gesso. 
Para o capim-colonião não foram observadas alterações significativas no teor de K na M.S. tanto no $1^{\circ}$. como no $2^{\circ}$. corte (Tabela 15 ).

PAULINO et al. (1989) observaram redução no teor de K na parte aérea do capim-andropogon em presença de calcário, provavelmente devido ao antagonismo (inibição competitiva) entre cálcio e magnésio com o potássio.

\subsubsection{Cálcio e Magnésio}

A elevação dos níveis de calcário proporcionou aumento altamente significativo na percentagem de Ca na M.S. dos cultivares IZ-1, Vencedor e Centenário no $1^{\circ}$. e $2^{\circ}$. cortes, conforme pode ser observado na Tabela 22. Para o cultivar Marandu, o teste de Tukey $5 \%$ não apontou diferença significativa no aumento deste nutriente. Entretanto, a análise de regressão polinomial mostrou aumento linear ascendente conforme a equação $\mathrm{Y}=0,2568+0,009 \mathrm{X}$ (Figura 14).

Em ambos os cortes houve interação altamente significativa, com comportamentos diferentes dos cultivares nos níveis de calcário. Para o Colonião IZ-1 a elevação do teor de $\mathrm{Ca}$ ocorreu a partir do $3^{\circ}$. nível de calagem $(\mathrm{V} \%=57,03)$, não se alterando segundo o teste Tukey a $5 \%$ no nível mais alto de correção do solo, no $1^{\circ}$. corte (Tabela 22), representada pela equação linear $\mathrm{Y}=0,2746+0,0209 \mathrm{X}$ (Figura 13). No $2^{\circ}$. corte, o aumento de $\mathrm{Ca}$ ocorreu no $2^{\circ}$. nível de calagem $(\mathrm{V} \%=42,07)$, tornando a aumentar com a dose mais alta do corretivo, onde a saturação por bases passou para $69,55 \%$, obedecendo a equação linear $Y=0,0251+0,0267 X$ (Figura 13). 

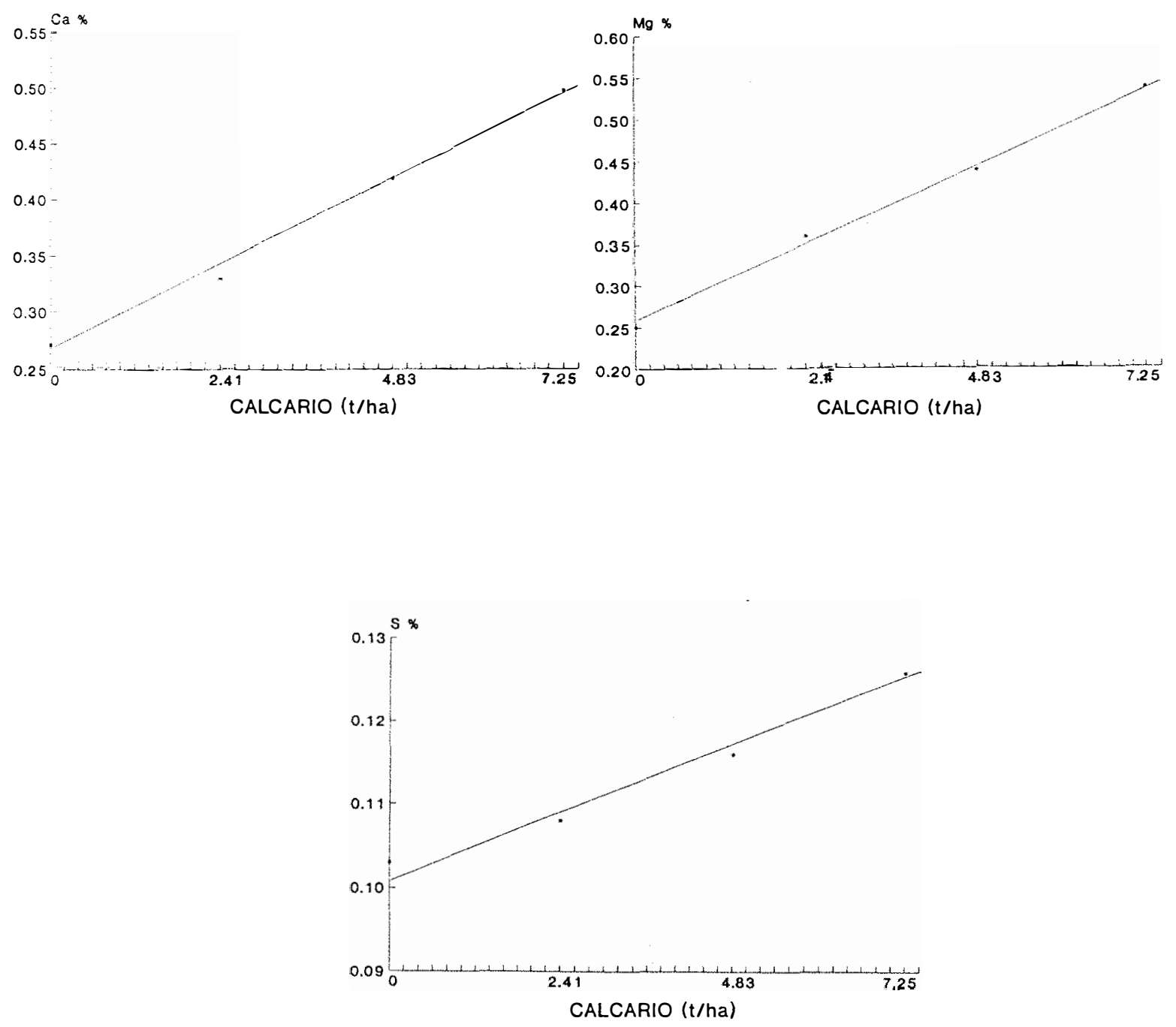

Figura 11. Efeito dos níveis de calcário na percentagem de $\mathrm{Ca}, \mathrm{Mg}$ e $\mathrm{S}$ na matéria seca da parte aérea dos cultivares Colonião IZ-1, Vencedor, Centenário e Marandu no $1^{\circ}$. corte. 

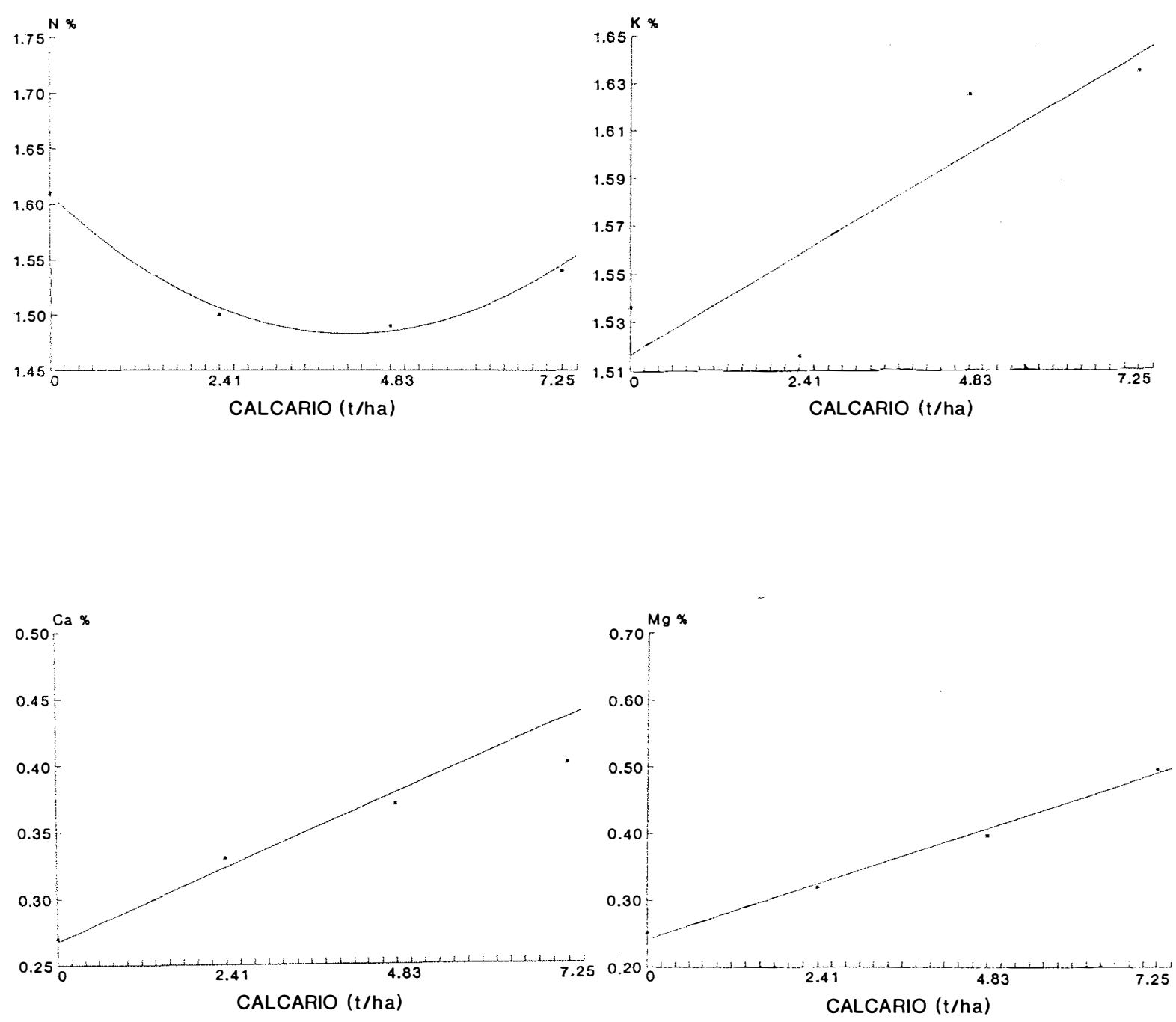

Figura 12. Efeito dos níveis de calcário na percentagem de $\mathrm{N}, \mathrm{K}, \mathrm{Ca}$ e $\mathrm{Mg}$ na matéria seca da parte aérea dos cultivares Colonião IZ-1, Vencedor, Centenário e Marandu no $2^{\circ}$. corte. 
Tabela 22. Percentagem de cálcio $(\mathrm{Ca}) \mathrm{n}$ a M.S. da parte aérea dos cultivares Colonião $\mathrm{IZ}-1$. Vencedor. Centenário e Marandu no $1^{\circ}$. e $2^{\circ}$. corte (médias de 16 repetiçōes).

\begin{tabular}{|c|c|c|c|c|c|c|c|c|c|c|}
\hline \multirow{2}{*}{$\begin{array}{l}\text { Niveis } \\
\text { de } \\
\text { calcário }\end{array}$} & \multicolumn{5}{|c|}{${ }^{\circ}$. corte } & \multicolumn{5}{|c|}{${ }^{\circ}$. corte } \\
\hline & $\begin{array}{l}\text { Médias } \\
16 \text { repet. }\end{array}$ & $\begin{array}{l}\text { Col. } \\
\text { IZ-I }\end{array}$ & $\begin{array}{c}\text { Vence- } \\
\text { dor }\end{array}$ & $\begin{array}{l}\text { Cente- } \\
\text { nário }\end{array}$ & $\begin{array}{c}\text { Maran- } \\
\mathrm{du}\end{array}$ & $\begin{array}{c}\text { Médias } \\
16 \text { repet. }\end{array}$ & $\begin{array}{l}\text { Col. } \\
\text { IZ-1 }\end{array}$ & $\begin{array}{c}\text { Vence- } \\
\text { dor }\end{array}$ & $\begin{array}{l}\text { Cente- } \\
\text { nário }\end{array}$ & $\begin{array}{l}\text { Maran- } \\
\text { du }\end{array}$ \\
\hline 1 & $0.27 \mathrm{~d}$ & $0.27 \mathrm{~d}$ & $0.35 \mathrm{~d}$ & $0,21 \mathrm{~d}$ & $0,26 \mathrm{a}$ & $0,27 d$ & $0,24 c$ & $0,34 c$ & $0,24 d$ & $0,24 \mathrm{a}$ \\
\hline 2 & $0.33 c$ & $0.32 \mathrm{~b}$ & $0,43 c$ & $0.29 \mathrm{c}$ & $0,28 \mathrm{a}$ & $0,33 c$ & $0,33 b$ & $0,41 b$ & $0,32 c$ & $0,25 \mathrm{a}$ \\
\hline 3 & $0,42 b$ & $0.4 \mathrm{a}$ & $0,60 \mathrm{~b}$ & $0,41 \mathrm{~b}$ & $0,28 \mathrm{a}$ & $0,37 b$ & $0,37 \mathrm{~b}$ & $0,43 b$ & $0,38 b$ & $0,30 \mathrm{a}$ \\
\hline 4 & $0.50 \mathrm{a}$ & $0,41 \mathrm{a}$ & $0.73 \mathrm{a}$ & $0.53 \mathrm{a}$ & $0,33 a$ & $0,44 a$ & $0,44 a$ & $0,55 \mathrm{a}$ & $0,47 a$ & $0,29 a$ \\
\hline Teste F & $* *$ & . & . & - & - & $* *$ & - & - & . & - \\
\hline Reg. linear & $(0,99)^{* *}$ & $(0,94)^{* *}$ & $(0,98)^{* *}$ & $(0.99)^{* *}$ & $(0.86)^{*}$ & $(0,99)^{* *}$ & $(0,99)^{* *}$ & $(0,92)^{* *}$ & $(0,99)^{* *}$ & $(0,74)^{*}$ \\
\hline C.V. $(\%)$ & 9.82 & . & - & - & - & 9,29 & - & - & - & - \\
\hline
\end{tabular}

Teste $\mathrm{F}$ para a interação niveis $\mathrm{x}$ cultivares: **

Niveis de significància: ${ }^{* *} 1 \%$; $5 \%$ : n.s. não significativo.

Médias seguidas pela mesma letra. dentro de cada coluna. não diferem entre si pelo teste de Tukey $5 \%$.

Os valores entre parènteses indicam o coeficiente de determinação $R^{2}$ para a equação.

Tabela 23. Percentagem de cálcio (Ca) na M.S. da parte aérea entre os cultivares Colonião IZ-1. Vencedor. Centenário e Marandu no $1^{\circ}$. e $2^{\circ}$. corte (médias de 4 repetições).

Cultivares

Ca $1^{\circ}$. corte

\begin{tabular}{c|l|l|l|l} 
Médias & 1 & 2 & 3 & 4 \\
16 repet. & & & &
\end{tabular}

$\mathrm{Ca} \quad 2^{\circ}$. corte

$\begin{array}{cllll}\text { Médias } & 1 & 2 & 3 & 4 \\ 16 \text { repet. } & & & & \end{array}$

\begin{tabular}{|c|c|c|c|c|c|c|c|c|c|c|}
\hline Col. IZ-1 & $0.35 b$ & $0.27 b$ & $0,32 b$ & $0.40 \mathrm{~b}$ & $0,41 \mathrm{c}$ & $0,35 b$ & $0,24 b$ & $0,33 \mathrm{~b}$ & $0,37 \mathrm{a}$ & $0,44 b$ \\
\hline Vencedor & $0.53 \mathrm{a}$ & $0,35 \mathrm{a}$ & $0,43 a$ & $0,60 \mathrm{a}$ & $0,73 a$ & $0,43 a$ & $0,34 \mathrm{a}$ & $0,41 \mathrm{a}$ & $0,43 a$ & $0,55 \mathrm{a}$ \\
\hline Centenário & $0.36 \mathrm{~b}$ & $0.2 \mathrm{lb}$ & $0.39 b$ & $0,41 b$ & $0,53 \mathrm{~b}$ & $0.35 b$ & $0,24 b$ & $0,32 \mathrm{~b}$ & $0,38 \mathrm{a}$ & $0,47 b$ \\
\hline Marandu & $0,29 c$ & $0.26 \mathrm{~b}$ & $0,28 \mathrm{~b}$ & $0,28 c$ & $0,33 d$ & $0.27 c$ & $0,24 b$ & $0,25 \mathrm{c}$ & $0,30 \mathrm{~b}$ & $0,29 c$ \\
\hline Teste F & ** & - & - & . & - & $* *$ & - & - & - & - \\
\hline C.V. $(\%)$ & 9,82 & - & - & . & - & 9.29 & - & - & - & - \\
\hline
\end{tabular}

Teste $\mathrm{F}$ para a interação niveis $\mathrm{x}$ cultivares: **

Niveis de significància: ${ }^{* *} 1 \%$; ${ }^{*} 5 \%$; n.s. não significativo.

Médias seguidas pela mesma letra. dentro de cada coluna, não difierem entre si pelo teste de Tukey $5 \%$. 

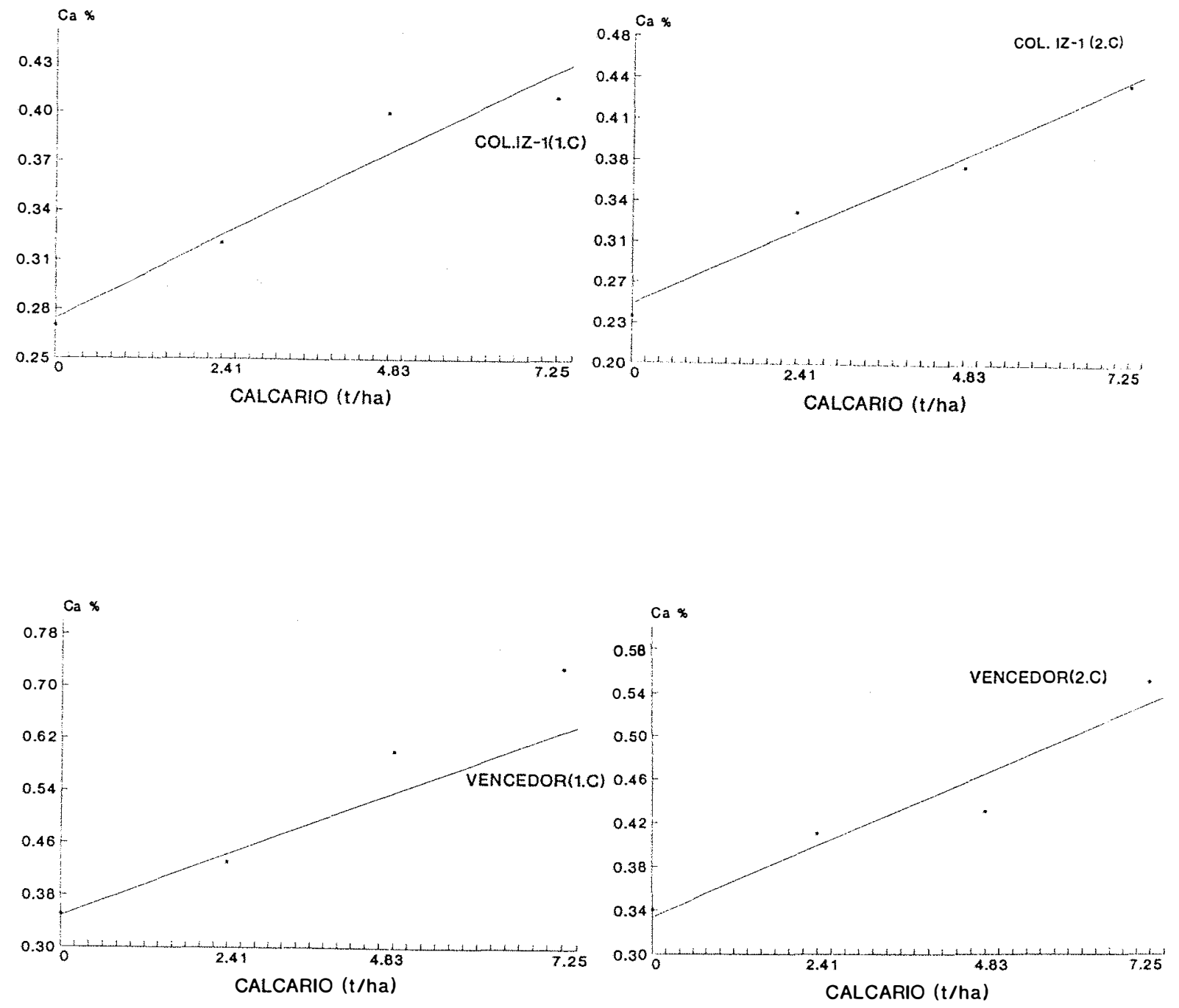

Figura 13. Efeito dos níveis de calcário na percentagem de Ca matéria seca da parte aérea para os cultivares Colonião IZ-1 e Vencedor no $1^{\circ}$. e $2^{\circ}$. corte. 

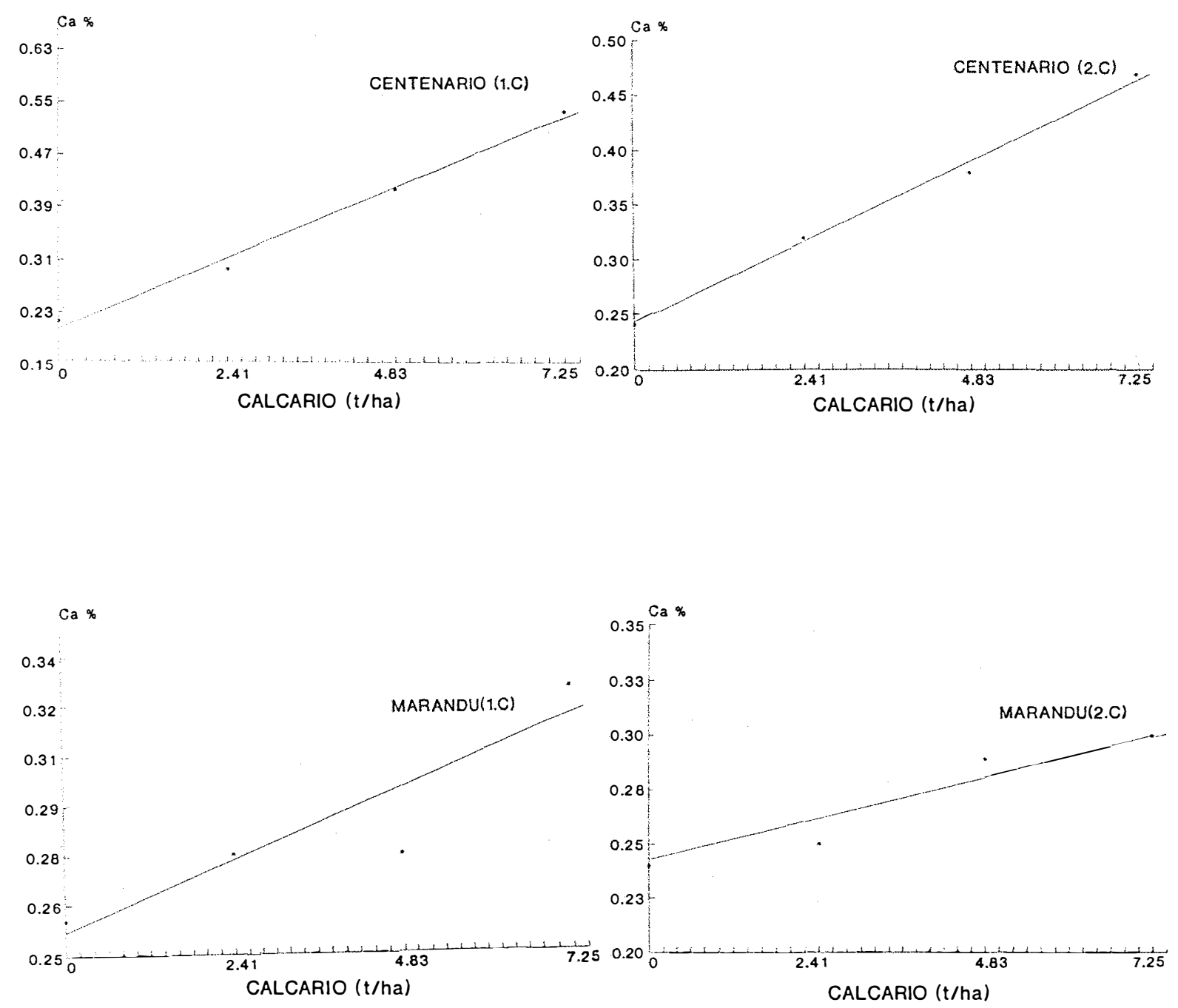

Figura 14. Efeito dos níveis de calcário na percentagem de Ca matéria seca da parte aérea para os cultivares Centenário e Marandu no $1^{\circ}$. e $2^{\circ}$. corte. 


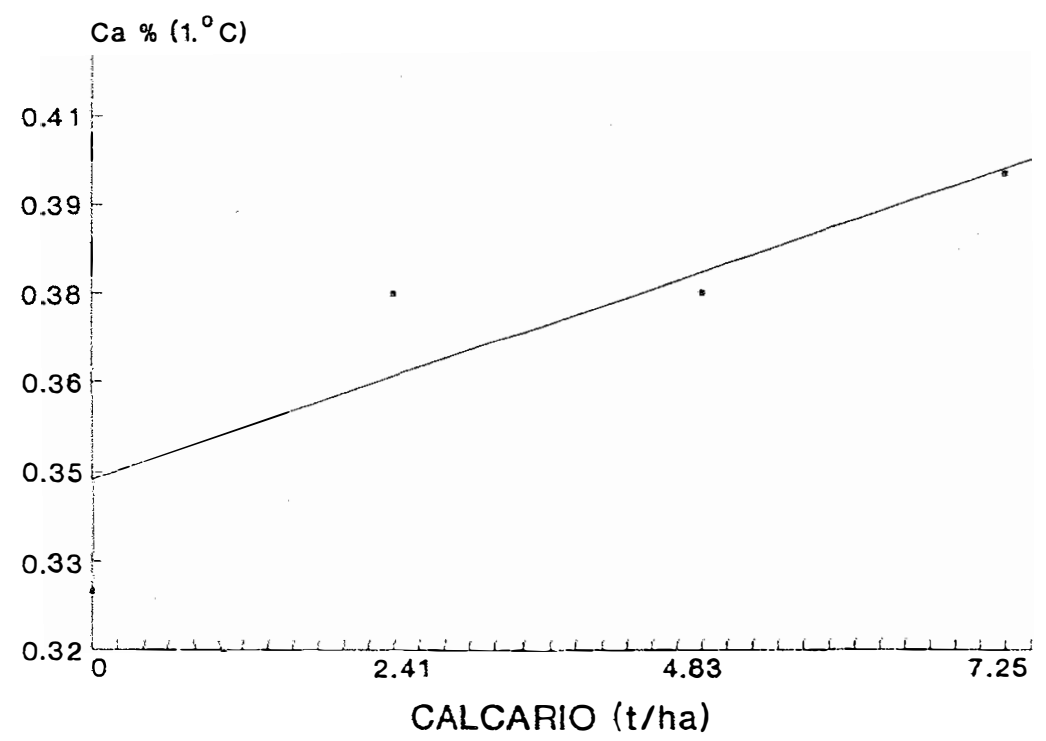

Figura 15. Efeito dos níveis de calcário na percentagem de $\mathrm{Ca}$ ( $1^{\circ}$. corte) na matéria seca da parte aérea do capim-andropogon. 
Já o Vencedor teve seus teores de Ca na M.S. aumentados a partir de $\mathrm{V} \%=30,81$, seguindo significativamente crescente até a dose máxima, no $1^{\circ}$. corte, cuja equação linear é $\mathrm{Y}=0,3484+0,0393 \mathrm{X}$ (Figura 13). No $2^{\circ}$. corte houve aumento com $42,07 \%$ de saturação por bases, tornando a aumentar significativamente quando V\% passou para $69,5 \%$, representado pela equação de regressão polinomial linear ascendente $\mathrm{Y}=$ $0,3336+0,0273 X$ (Figura 13)

$\mathrm{O}$ cultivar Centenário teve seu teor de $\mathrm{Ca}$ aumentado de acordo com o nível de correção do solo utilizado, aumentando até a dose máxima de calagem, em ambos os cortes (Tukey 5\%), representados pelas equações $\mathrm{Y}=0,1994+0,0447 \mathrm{X}$ e $\mathrm{Y}=$ $0,2431+0,0307 \mathrm{X}$, para o $1^{\circ}$. e $2^{\circ}$. cortes respectivamente (Figura 14)

$\mathrm{O}$ cultivar Marandu apresentou apenas tendência de aumento de $\mathrm{Ca}$ na M.S. não sendo significativo pelo teste de Tukey no $1^{\circ}$. e $2^{\circ}$. cortes. No entanto, as equações de regressão mostraram comportamento linear ascendente $\mathrm{Y}=0,2568+0,009 \mathrm{X}$ e $\mathrm{Y}=0,2430+0,0079 \mathrm{X}$ (Figura 14).

O cultivar Vencedor apresentou maior teor de Ca na M.S. nos dois cortes em todos os níveis de correção do solo, com exceção do $3^{\circ}$. nível de calcário no $2^{\circ}$. corte (Tabela 23).

No $1^{\circ}$. corte, Colonião IZ-1, Centenário e Marandu não diferiram entre si na percentagem de Ca na M.S. nos níveis 1 e 2 de calcário, onde V\% foi 30,81 e $45,81 \%$, respectivamente. No nível 3 , com $V \%=57,03$, Centenário e IZ-1 apresentaram teores de Ca sem diferença significativa e no último nível de saturação por base todos os cultivares foram diferentes entre si. 
No $2^{\circ}$. corte, observou-se que Colonião IZ-1, Centenário e Marandu não diferiram entre si quanto ao teor de Ca na ausência do corretivo, com V\% $=27,8$ (nível 1). Com V\%= 42,07 (nível 2), Colonião IZ-1 e Centenário não diferiram entre si, porém apresentaram maior teor de $\mathrm{Ca}$ que o cultivar Marandu. No nível 3 de calcário, quando a V\% atingiu 57,16, os cultivares Colonião IZ-1 e Centenário não diferiram significativamente do cultivar Vencedor quanto à percentagem de Ca na M.S. O cultivar Marandu apresentou menor teor desse elemento. No nível mais alto de calagem com V\% $=69,55$ os cultivares Colonião IZ-1 e Centenário não foram diferentes entre si, porém apresentaram menor teor de $\mathrm{Ca}$ que o Vencedor e maior teor que o cultivar Marandu (Tabela 23).

A elevação dos níveis de saturação por bases através da calagem proporcionou aumentos significativos $(\mathrm{p}<0,01)$ na percentagem de magnésio na M.S. dos cultivares Colonião IZ-1, Vencedor, Centenario e Marandu no $1^{\circ}$. e $2^{\circ}$. cortes (Tabela 24).

Houve interação significativa entre os fatores níveis e cultivares ( $p$ $<0,01)$ no $1^{\circ}$. corte e $(\mathrm{p}<0,05)$ no $2^{\circ}$. corte, com diferentes percentagens de $\mathrm{Mg}$ nas espécies, dependendo do nível de saturação por bases atingida com a utilização do corretivo (Tabela 24).

No $1^{\circ}$. corte, os cultivares Colonião IZ-1, Vencedor e Centenário apresentaram aumentos na percentagem de $\mathrm{Mg}$ a partir de 45,81\% de saturação por bases, aumentando significativamente até $68,83 \%$ (teste de Tukey $5 \%$ ). Este aumento foi linear conforme representada pelas equações de regressão $\mathrm{Y}=0,2016+0,0316 \mathrm{X}, \mathrm{Y}=0,3032+$ 
Tabela 24. Percentagem de magnésio (Mg) na M.S. da parte aérea dos cultivares Colonião IZ-1, Vencedor. Centenário e Marandu no $1^{\circ}$. e $2^{\circ}$. corte (médias de 4 repetições).

\begin{tabular}{|c|c|c|c|c|c|c|c|c|c|c|}
\hline \multirow{2}{*}{$\begin{array}{l}\text { Niveis } \\
\text { de } \\
\text { calcário }\end{array}$} & \multicolumn{5}{|c|}{$\operatorname{Mg} \quad 1^{\circ}$. corte } & \multicolumn{5}{|c|}{$2^{\circ}$. corte } \\
\hline & $\begin{array}{l}\text { Médias } \\
16 \text { repet. }\end{array}$ & $\begin{array}{l}\text { Col. } \\
\text { IZ-I }\end{array}$ & $\begin{array}{l}\text { Vence- } \\
\text { dor }\end{array}$ & $\begin{array}{l}\text { Cente- } \\
\text { nário }\end{array}$ & $\begin{array}{c}\text { Maran- } \\
\text { du }\end{array}$ & $\begin{array}{l}\text { Médias } \\
16 \text { repet. }\end{array}$ & $\begin{array}{l}\text { Col. } \\
\text { IZ-1 }\end{array}$ & $\begin{array}{c}\text { Vence- } \\
\text { dor }\end{array}$ & $\begin{array}{l}\text { Cente- } \\
\text { nário }\end{array}$ & $\begin{array}{l}\text { Maran- } \\
\mathrm{du}\end{array}$ \\
\hline 1 & $0,25 \mathrm{~d}$ & $0,21 \mathrm{~d}$ & $0,31 \mathrm{~d}$ & $0,23 \mathrm{~d}$ & $0,27 \mathrm{c}$ & $0,25 \mathrm{~d}$ & $0,21 \mathrm{c}$ & $0,25 \mathrm{c}$ & $0.20 \mathrm{~d}$ & $0,31 \mathrm{c}$ \\
\hline 2 & $0,36 \mathrm{c}$ & $0,27 c$ & $0,44 \mathrm{c}$ & $0,33 c$ & $0.40 \mathrm{~b}$ & $0,32 \mathrm{c}$ & $0,28 \mathrm{~b}$ & $0,35 b$ & $0.28 \mathrm{c}$ & $0,38 \mathrm{~b}$ \\
\hline 3 & $0.44 b$ & $0,35 b$ & $0,56 \mathrm{~b}$ & $0,41 \mathrm{~b}$ & $0,44 a b$ & $0,40 \mathrm{~b}$ & $0,33 b$ & $0,41 \mathrm{~b}$ & $0,40 \mathrm{~b}$ & $0,46 \mathrm{a}$ \\
\hline 4 & $0,54 \mathrm{a}$ & $0,44 a$ & $0,72 a$ & $0,53 \mathrm{a}$ & $0,48 \mathrm{a}$ & $0,50 \mathrm{a}$ & $0,42 \mathrm{a}$ & $0,57 \mathrm{a}$ & $0,53 \mathrm{a}$ & $0,50 \mathrm{a}$ \\
\hline Teste F & $* *$ & - & - & - & - & $* *$ & . & - & - & - \\
\hline Reg. linear & $(0,99)^{* *}$ & $(0,99)^{* *}$ & $(0,99)^{* *}$ & $(0,99)^{* *}$ & ** & $(0,99)^{* *}$ & $(0,98)^{* *}$ & $(0,96)^{* *}$ & $(0,99)^{* *}$ & $(0,98)^{* *}$ \\
\hline Reg. quadrática & n.s. & n.s. & n.s. & n.s. & $(0,98)^{* *}$ & n.s. & n.s. & n.s. & n.s. & n.s. \\
\hline C.V. $\left({ }^{0} \%\right)$ & 7,88 & - & - & - & - & 9,87 & - & - & - & - \\
\hline
\end{tabular}

Teste $\mathrm{F}$ para a interação niveis $\mathrm{x}$ cultivares: *

Niveis de significància: $* * 1 \%$; $5 \%$ : n.s. não significativo.

Médias seguidas pela mesma letra, dentro de cada coluna, não difierem entre si pelo teste de Tukey $5 \%$.

Os valores entre parènteses indicam o coeficiente de determinação $R^{2}$ para a equação.

Tabela 25. Percentagem de magnésio (Mg) na M.S. da parte aérea entre os cultivares Colonião IZ-1, Vencedor. Centenário e Marandu no $1^{\circ}$. e $2^{\circ}$. corte (médias de 4 repetições).

\begin{tabular}{|c|c|c|c|c|c|c|c|c|c|c|}
\hline \multirow{3}{*}{ Cukivares } & \multicolumn{10}{|c|}{ Niveis de calagem } \\
\hline & \multicolumn{2}{|r|}{$\mathrm{Mg}$} & \multicolumn{2}{|c|}{$1^{\circ}$. corte } & \multirow[b]{2}{*}{4} & \multicolumn{2}{|c|}{$\mathrm{Mg}$} & \multicolumn{2}{|c|}{$2^{\circ}$. corte } & \multirow[b]{2}{*}{4} \\
\hline & $\begin{array}{l}\text { Médias } \\
16 \text { repet. }\end{array}$ & 1 & 2 & 3 & & $\begin{array}{l}\text { Médias } \\
16 \text { repet. }\end{array}$ & 1 & 2 & 3 & \\
\hline Col. IZ-I & $0,32 c$ & $0,21 \mathrm{c}$ & $0,27 b$ & $0,35 \mathrm{c}$ & $0,44 \mathrm{c}$ & $0,31 \mathrm{c}$ & $0,21 b$ & $0,28 \mathrm{~b}$ & $0,33 b$ & $0,42 \mathrm{c}$ \\
\hline Vencedor & $0.51 \mathrm{a}$ & $0,31 \mathrm{a}$ & $0,44 a$ & $0,56 \mathrm{a}$ & $0,72 \mathrm{a}$ & $0.40 \mathrm{a}$ & $0,25 \mathrm{ab}$ & $0,35 \mathrm{ab}$ & $0.41 \mathrm{a}$ & $0,57 \mathrm{a}$ \\
\hline Centenário & $0,38 b$ & $0,23 \mathrm{bc}$ & $0,33 b$ & $0,41 \mathrm{~b}$ & $0,53 \mathrm{~b}$ & $0,35 b$ & $0,20 \mathrm{~b}$ & $0,28 \mathrm{~b}$ & $0,40 \mathrm{ab}$ & $0,53 \mathrm{ab}$ \\
\hline Marandu & $0,40 \mathrm{~b}$ & $0,27 \mathrm{ab}$ & $0,40 \mathrm{a}$ & $0,44 b$ & $0,48 \mathrm{bc}$ & $0,41 \mathrm{a}$ & $0,31 \mathrm{a}$ & $0,38 \mathrm{a}$ & $0.46 \mathrm{a}$ & $0,50 \mathrm{~b}$ \\
\hline Teste F & $* *$ & - & - & - & - & ** & - & - & - & - \\
\hline C.V. $\left({ }^{\circ} \%\right)$ & 7.88 & - & - & - & - & 9,87 & - & - & - & - \\
\hline
\end{tabular}

Teste $\mathrm{F}$ para a interação niveis $\mathrm{x}$ cultivares: *

Niveis de significància: ** $1 \%$; $5 \%$; n.s. não significativo.

Médias seguidas pela mesma letra, dentro de cada coluna, não diferem entre si pelo teste de Tukey $5 \%$. 

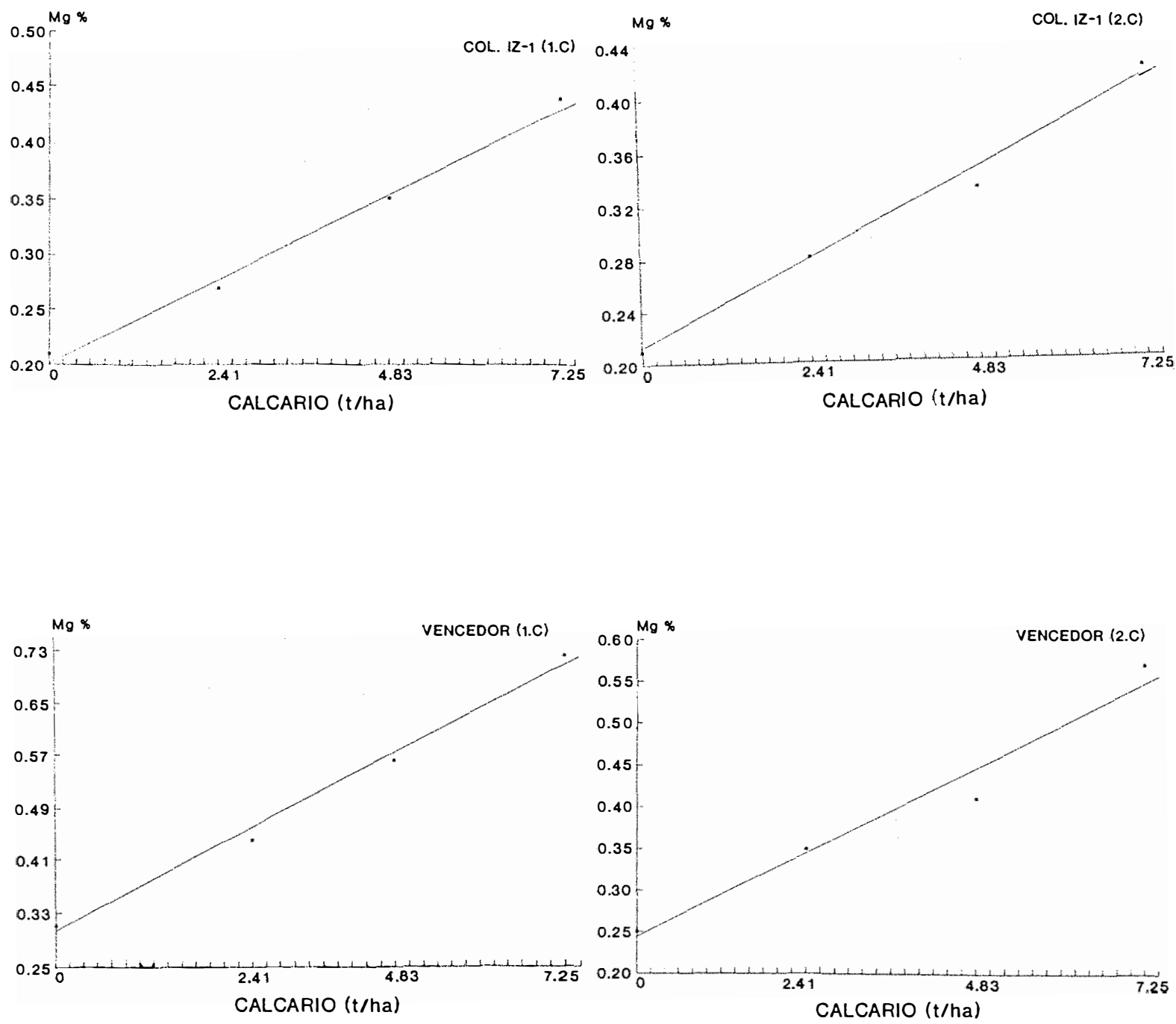

Figura 16. Efeito dos níveis de calcário na percentagem de Mg na matéria seca da parte aérea dos cultivares Colonião IZ-1 e Vencedor, no $1^{\circ}$. e $2^{\circ}$. corte. 

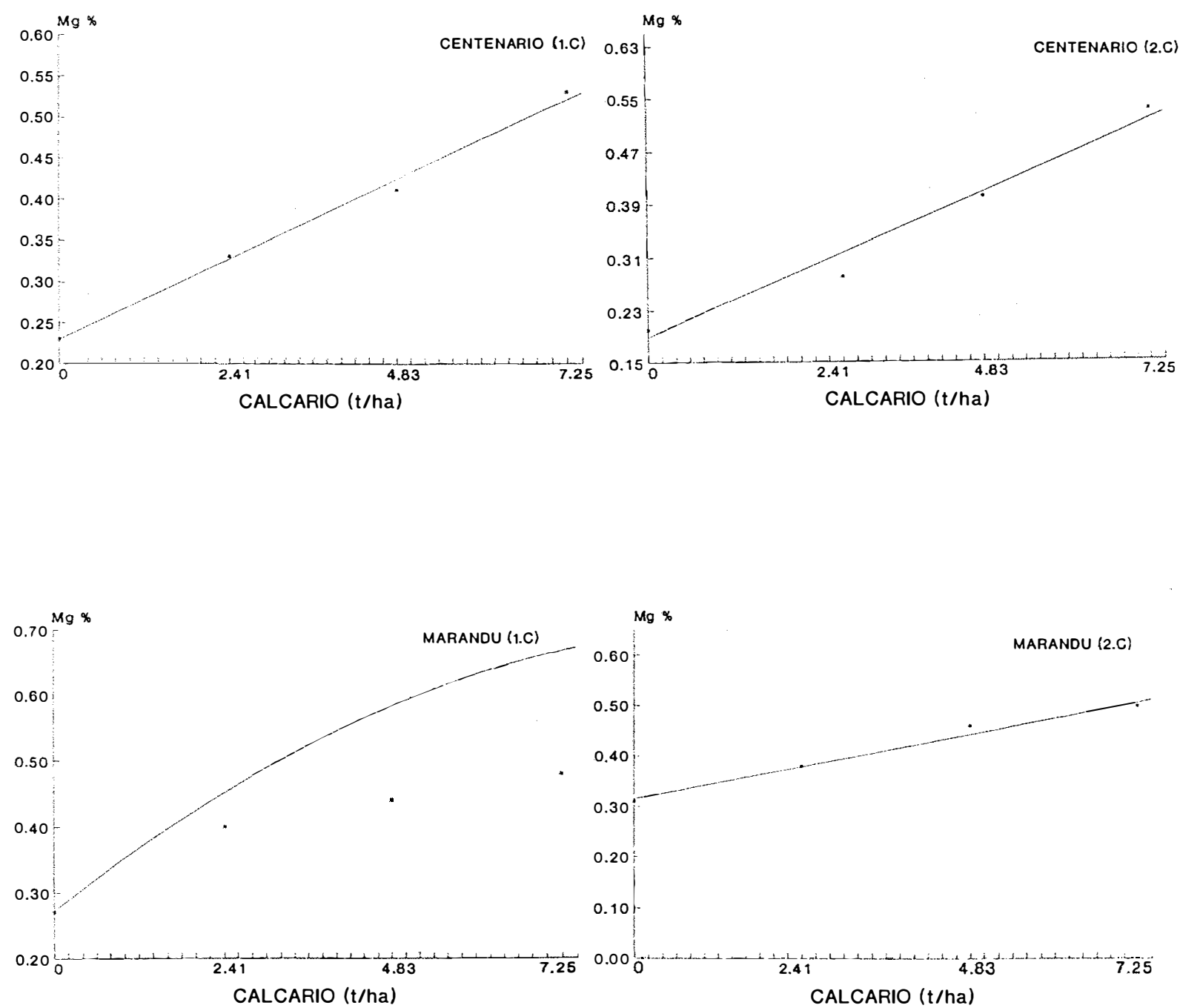

Figura 17. Efeito dos níveis de calcário na percentagem de Mg na matéria seca da parte aérea dos cultivares Centenário e Marandu, no $1^{\circ}$. e $2^{\circ}$. corte. 
0,0561 e $\mathrm{Y}=0,2301+0,0403 \mathrm{X}$, respectivamente (Figuras 16 e 17). Para o cultivar Marandu a percentagem de $\mathrm{Mg}$ aumentou com $\mathrm{V} \%=45,81$ aumentando novamente no último nível de calagem com $\mathrm{V} \%$ - 68,83, de forma quadrática conforme a equação $\mathrm{Y}=$ $0,2725+0,0844 X-0,0041 X^{2}($ Figura 17)

Observou-se diferença nos teores de $\mathrm{Mg}$ entre os cultivares dentro dos níveis de calcário estudados (Tabela 25). Nos níveis 1 e 2 com $\mathrm{V} \%=30,81$ e V\%=45,81, respectivamente, os cultivares Vencedor e Marandu não apresentaram diferenças significativas nas percentagens de Mg na M.S. O Vencedor apresentou maior percentagem desse nutriente nos níveis 3 e 4 com $V \%=57,03$ e 68,83; Marandu e Centenário não diferiram entre si e o Colonião IZ-1 apresentou o menor teor de Mg dentro do nível 3 de calcário.

No $2^{\circ}$. corte, Tabela 24 , os cultivares Colonião IZ-1 e Vencedor apresentaram aumento na percentagem de $\mathrm{Mg}$ a partir do nível 2 de calcário, $\mathrm{V}=42,07$, voltando a apresentar aumento somente no $4^{\circ}$. nível, quando $\mathrm{V} \%$ passou para 69,55 . Tais aumentos foram lineares representados pelas equações $\mathrm{Y}=0,2131+0,0276 \mathrm{X}$ e $\mathrm{Y}=0,2444$ $+0,0421 \mathrm{X}$, respectivamente (Figura 16). O cultivar Centenário apresentou aumentos significtivos desde o nível 2 , com $\mathrm{V} \%=42,07$, seguindo crescente até o último nível de calcário onde V\% foi 69,55. O cultivar Marandu teve seu teor de Mg aumentado até o nível 3 , ou seja, $V \%=57,16$. A equação de regressão polinomial mostrou aumentos lineares cujas equações foram $\mathrm{Y}=0,1896+0,0453 \mathrm{X}$ e $\mathrm{Y}=0,3156+0,0266 \mathrm{X}$, para o Centenário e Marandu, respectivamente (Figura 17). 
Tabela 26. Percentagem de enxofre (S) na M.S. da parte aérea dos cultivares Colonião IZ-1, Vencedor, Centenário e Marandu no $1^{\circ}$. e $2^{\circ}$. corte (médias de 4 repetições).

\begin{tabular}{|c|c|c|c|c|c|c|}
\hline \multirow{2}{*}{$\begin{array}{l}\text { Niveis } \\
\text { de } \\
\text { calagem }\end{array}$} & \multicolumn{5}{|c|}{$1^{\circ}$. corte } & \multirow{2}{*}{ 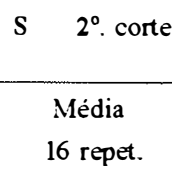 } \\
\hline & $\begin{array}{l}\text { Médias } \\
16 \text { repet. }\end{array}$ & $\begin{array}{c}\text { Colonião } \\
\text { IZ-1 }\end{array}$ & $\begin{array}{l}\text { Vence- } \\
\text { dor }\end{array}$ & $\begin{array}{l}\text { Cente- } \\
\text { nário }\end{array}$ & Marandu & \\
\hline 1 & $0,10 \mathrm{~b}$ & $0,07 \mathrm{a}$ & $0.11 \mathrm{c}$ & $0.12 \mathrm{~b}$ & $0.11 \mathrm{a}$ & $0.09 \mathrm{a}$ \\
\hline 2 & $0,11 \mathrm{~b}$ & $0,07 \mathrm{a}$ & $0,12 b c$ & $0,13 \mathrm{ab}$ & $0,10 \mathrm{a}$ & $0,09 \mathrm{a}$ \\
\hline 3 & $0.12 \mathrm{ab}$ & $0,08 \mathrm{a}$ & $0,14 \mathrm{ab}$ & $0,15 \mathrm{ab}$ & $0,09 \mathrm{a}$ & $0.09 \mathrm{a}$ \\
\hline 4 & $0,13 \mathrm{a}$ & $0,08 \mathrm{a}$ & $0,17 \mathrm{a}$ & $0,15 \mathrm{a}$ & $0,10 \mathrm{a}$ & $0.10 \mathrm{a}$ \\
\hline Teste F & $* *$ & - & . & - & - & n.s. \\
\hline Reg. linear & $(0,95)^{* *}$ & n.s. & $(0,97)^{* *}$ & $(0,98)^{* *}$ & n.s. & n.s. \\
\hline C.V. $\left({ }^{\circ} \%\right)$ & 13,95 & . & - & - & . & 14,81 \\
\hline
\end{tabular}

Teste $\mathrm{F}$ para a interação niveis $\mathrm{x}$ cultivares no $1^{\circ}$. corte: *

Niveis de significância: ${ }^{* *} 1 \% ; * 5 \%$; n.s. não significativo.

Médias seguidas pela mesma letra, dentro de cada coluna, não diferem entre si pelo teste de Tukey $5 \%$.

Os valores entre parênteses indicam o coeficiente de determinação $R^{2}$ para a equação.

Tabela 27. Percentagem de nitrogènio (N), fösforo (P), potássio $(\mathrm{K})$ e enxofre (S) na M.S. da parte aérea entre os cultivares Colonião IZ-1, Vencedor. Centenário e Marandu no $1^{\circ}$. e $2^{\circ}$.-corte (médias de 16 repetições).

\begin{tabular}{|c|c|c|c|c|c|c|c|c|}
\hline \multirow{2}{*}{ Cultivares } & \multicolumn{2}{|c|}{$\mathrm{N}$} & \multicolumn{2}{|c|}{$P$} & \multicolumn{2}{|c|}{$\mathrm{K}$} & \multicolumn{2}{|c|}{$S$} \\
\hline & $1^{\circ}$. corte & $2^{\circ}$. corte & $1^{\circ}$. corte & $2^{\circ}$. corte & $1^{\circ}$. corte & $2^{\circ}$. corte & $1^{\circ}$. corte & $2^{\circ}$. corte \\
\hline Colonião IZ,-1 & $1,64 \mathrm{~b}$ & $1,58 \mathrm{a}$ & $0,12 \mathrm{~b}$ & $0,13 \mathrm{a}$ & $2,14 \mathrm{~b}$ & $1,52 \mathrm{~b}$ & $0,08 \mathrm{c}$ & $0,08 \mathrm{~b}$ \\
\hline Vencedor & $1.76 \mathrm{ab}$ & $1,48 \mathrm{a}$ & $0,12 \mathrm{~b}$ & $0,13 \mathrm{a}$ & $2,55 \mathrm{a}$ & $1,63 \mathrm{ab}$ & $0.13 \mathrm{a}$ & $0,09 \mathrm{~b}$ \\
\hline Centenário & $1,84 \mathrm{a}$ & $1,57 \mathrm{a}$ & $0,12 \mathrm{~b}$ & $0,13 \mathrm{a}$ & $2,54 \mathrm{a}$ & $1,67 \mathrm{a}$ & $0,14 \mathrm{a}$ & $0,12 \mathrm{a}$ \\
\hline Marandu & $1,90 \mathrm{a}$ & $1,52 \mathrm{a}$ & $0,14 \mathrm{a}$ & 0,13 a & $2,22 \mathrm{~b}$ & $1,51 \mathrm{~b}$ & $0,10 \mathrm{~b}$ & $0,09 \mathrm{~b}$ \\
\hline Teste F & * & n.s. & $* *$ & n.s. & $* *$ & ** & $* *$ & $* *$ \\
\hline C.V. $(\%)$ & 11,53 & 9,78 & 7,25 & 7,54 & 7,52 & 8,20 & 13.95 & 14.81 \\
\hline
\end{tabular}

Niveis de significância: $* * 1 \% ; * 5 \%$; n.s. não significativo.

Médias seguidas pela mesma letra, dentro de cada coluna, não difierem entre si pelo teste de Tukey $5 \%$. 
Com a V\%=42,07 o cultivar Marandu apresentou maior percentagem de Mg na M.S. que os cultivares Colonião IZ-1 e Centenário. Com V\% = 57,16 (nível 3 de calcário) o Colonião IZ-1 apresentou igual teor de Mg que o cultivar Centenário. No último nível, com V\% $=69,55$, o cultivar Colonião IZ-1 apresentou a menor percentagem deste nutriente.

Para o capim-andropogon, Tabela 29, não houve efeito significativo dos níveis de calcário nas percentagens de $\mathrm{Ca}$ e $\mathrm{Mg}$ na M.S. no $1^{\circ}$. e $2^{\circ}$. cortes. $\mathrm{A}$ análise de regressão polinomial mostrou aumento linear de Ca na M.S. do $1^{\circ}$. corte conforme a equação $Y=0,3488+0,0072 X$ (Figura 15). PAULINO et al. (1989), observaram ausência de resposta à calagem no teor de Ca na M.S. ( $1^{\circ}$. corte), e resposta positiva ao corretivo no teor de $\mathrm{Ca}\left(2^{\circ}\right.$. corte $)$ e $\mathrm{Mg}\left(1^{\circ}\right.$. e $2^{\circ}$. cortes $)$.

A elevação dos teores de $\mathrm{Ca}$ e $\mathrm{Mg}$ na M.S. de gramíneas forrageiras com a elevação de doses de calcário são amplamente relatados pela literatura (ABRUÑA et al., 1964; WERNER et al., 1979; GOMIDE et al., 1986; CARRIEL et al., 1989; PAULINO, 1990 e PREMAZZI, 1991).

\subsubsection{Enxofre}

A percentagem de $S$ na M.S. do cultivar Vencedor aumentou significativamente a partir de $\mathrm{V} \%=45,81$ (nível 2 ) e para o cultivar Centenário a partir de 57,03 (nível 3). Os aumentos foram lineares, segundo as equações de regressão polinomial $\mathrm{Y}=0,1058+0,0081 \mathrm{X}$ e $\mathrm{Y}=0,1208+0,0049 \mathrm{X}$, respectivamente (Figura 18). Para os

cultivar Colonião IZ-1 e Marandu não houve influência da calagem no teor de S na M.S. do $1^{\circ}$. corte (Tabela 26$)$. 
Tabela 28. Percentagem de enxofre (S) na M.S. da parte aérea entre os cultivares Colonião IZ-1. Vencedor. Centenário e Marandu no $1^{\circ}$. corte (médias de 4 repetiçōes).

\begin{tabular}{|c|c|c|c|c|c|}
\hline \multirow{2}{*}{ Cultivares } & \multirow{2}{*}{$\begin{array}{l}\text { Médias } \\
\text { de } 16 \\
\text { repetições }\end{array}$} & \multicolumn{4}{|c|}{ Niveis de calagem } \\
\hline & & 1 & 2 & 3 & 4 \\
\hline Colonião IZ-1 & $0,08 \mathrm{c}$ & $0,07 \mathrm{~b}$ & $0,07 \mathrm{c}$ & $0,08 \mathrm{~b}$ & $0,08 \mathrm{~b}$ \\
\hline Vencedor & $0,13 \mathrm{a}$ & $0,11 \mathrm{a}$ & $0.12 a b$ & $0.14 \mathrm{a}$ & $0,17 \mathrm{a}$ \\
\hline Centenário & $0,14 \mathrm{a}$ & $0,12 \mathrm{a}$ & $0,13 \mathrm{a}$ & $0,15 \mathrm{a}$ & $0,15 \mathrm{a}$ \\
\hline Marandu & $0.10 \mathrm{~b}$ & $0,11 \mathrm{a}$ & $0.10 \mathrm{bc}$ & $0.09 \mathrm{~b}$ & $0,10 \mathrm{~b}$ \\
\hline Teste F & $* *$ & - & - & . & - \\
\hline C.V. $(\%)$ & 13,95 & - & - & - & $=$ \\
\hline
\end{tabular}

Teste $\mathrm{F}$ para a interação niveis $\mathrm{x}$ cultivares: *

Niveis de significância: $* * 1 \% ; \%$; n.s. não significativo.

Médias seguidas pela mesma letra. dentro de cada coluna, não diferem entre si pelo teste de Tukey $5 \%$.

Tabela 29. Percentagem de cálcio (Ca), magnésio (Mg) e enxofre (S) na M.S. da parte aérea do capim-andropogon no $1^{\circ}$. e $2^{\circ}$. corte (médias de 4 repetições).

\begin{tabular}{|c|c|c|c|c|c|c|}
\hline \multirow{2}{*}{$\begin{array}{l}\text { Niveis } \\
\text { de } \\
\text { calcário }\end{array}$} & \multicolumn{3}{|c|}{$1^{\circ}$. corte } & \multicolumn{3}{|c|}{$2^{\circ}$. corte } \\
\hline & $\mathrm{Ca}$ & $\mathrm{Mg}$ & $s$ & $\mathrm{Ca}$ & $\mathrm{Mg}$ & $s$ \\
\hline 1 & $0,33 \mathrm{a}$ & 0,15 a & $0,07 \mathrm{a}$ & $0,28 \mathrm{a}$ & $0,18 \mathrm{a}$ & $0,05 \mathrm{a}$ \\
\hline 2 & $0.38 \mathrm{a}$ & 0,17 a & $0,08 \mathrm{a}$ & 0,39 a & $0,24 \mathrm{a}$ & $0,03 \mathrm{a}$ \\
\hline 3 & $0.40 \mathrm{a}$ & 0,17 a & $0,08 \mathrm{a}$ & $0,35 \mathrm{a}$ & $0,22 \mathrm{a}$ & $0,05 \mathrm{a}$ \\
\hline 4 & $0,38 \mathrm{a}$ & $0,19 \mathrm{a}$ & 0,09 a & 0,39 a & $0,25 \mathrm{a}$ & $0,05 \mathrm{a}$ \\
\hline Teste F & n.s. & n.s. & n.s. & n.s. & n.s. & n.s. \\
\hline Reg. linear & $(0,52)^{*}$ & n.s. & n.s. & n.s. & n.s. & n.s. \\
\hline Reg. quadrática & n.s. & n.s. & n.s. & n.s. & n.s. & n.s. \\
\hline C.V. $(\%)$ & 9,02 & 14,85 & 20,60 & 23,51 & 19.76 & 37,30 \\
\hline
\end{tabular}

Niveis de significância: ** $1 \%$; * 5\%; n.s. não significativo.

Médias seguidas pela mesma letra, dentro de cada coluna, não diferem entre si pelo teste de Tukey $5 \%$.

Os valores entre parênteses indicam o coeficiente de determinação $R^{2}$ para a equação. 

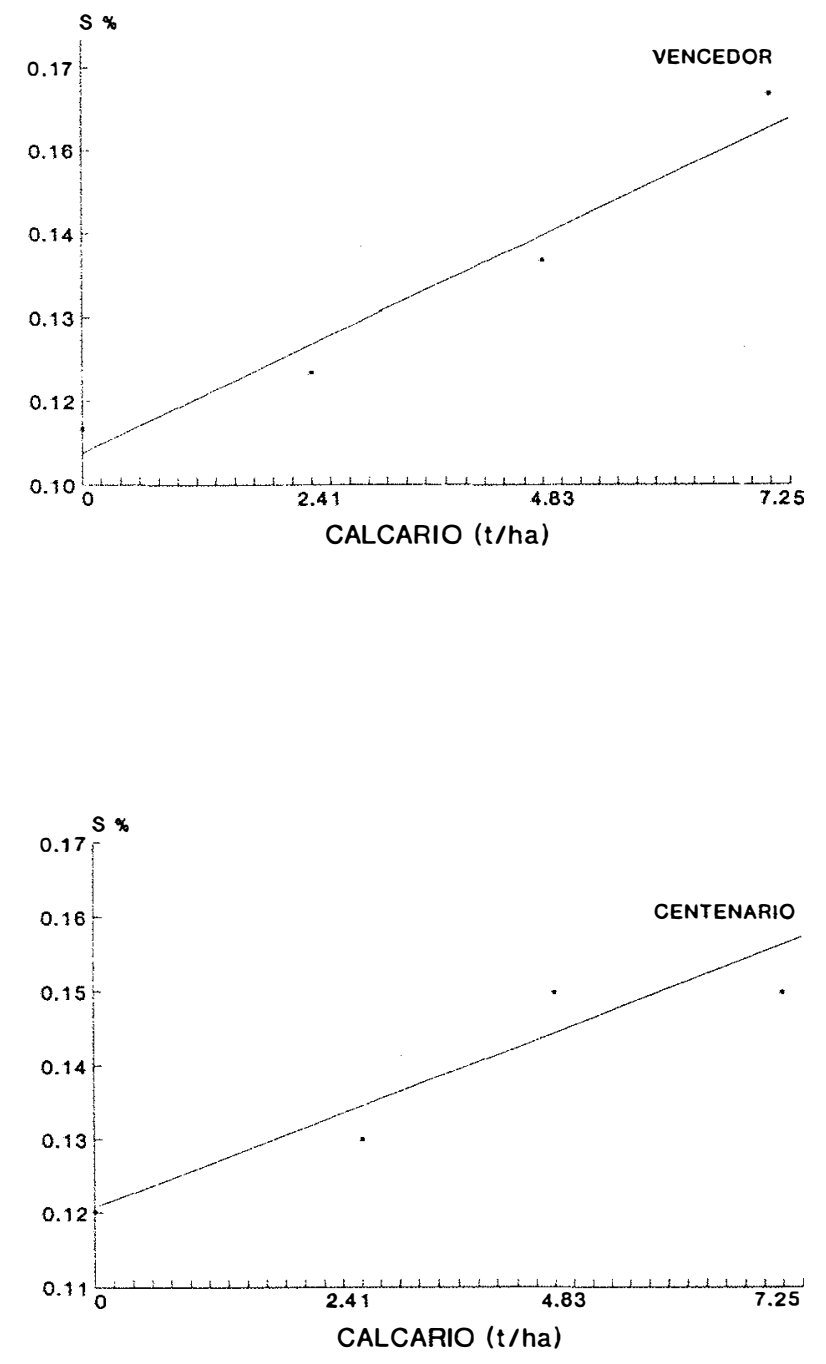

Figura 18. Efeito dos níveis de calcário na percentagem e $\mathrm{S}$ na matéria seca da parte aérea dos cultivares Vencedor e Centenário no $1^{\circ}$. corte. 
No nível 1 de calagem, com $30,81 \%$ de saturação por bases, Centenário, Vencedor e Marandu apresentaram maior teor de S que o Colonião IZ-1 (Tabela 28). Nos níveis mais elevados onde $\mathrm{V} \%=57,03$ e 68,83 (níveis 3 e 4 , respectivamente) os cultivares Centenário e Vencedor apresentaram maior teor de S na M.S. que os cultivares Marandu e Colonião IZ-1.

No $2^{\circ}$. corte houve diferença significativa $(\mathrm{p}<0,01)$ para maior percentagem de S na M.S. do cultivar Centenário (Tabela 27). Os cultivares Vencedor, Colonião IZ-1 e Marandu não apresentaram diferenças significativas entre si.

A adubação com $\mathbf{S}$ foi realizada levando-se em consideração as espécies estudadas, a condução do trabalho em vasos, e recomendações da literatura (CASAGRANDE \& SOUZA, 1982; HADDAD, 1983; VITTI \& NOVAES, 1986; WERNER, 1986).

GALLO et al. (1974), analisando um total de 249 amostras de forrageiras, sendo 122 gramíneas, observaram que 51,6\% das gramíneas ( $15,0 \%$ de coleções e $69,6 \%$ de pastagens), apresentaram teores menores que $0,1 \%$ de S. A média geral para o capim-colonião foi $0,06 \%$ com intervalo de dispersão de 0,012 e $0,167 \%$ de S na M.S.

SMITH \& DOLBY (1977) trabalharam com P. maxim um cv. Green Panic em casa de vegetação, estudando o nível crítico de S na M.S. da parte aérea da rebrota. Encontraram como nível crítico o teor de $0,08 \%$ para o período de crescimento de 32 dias após a rebrota. Os autores comentaram ainda o uso da relação $\mathrm{N}: \mathrm{S}=13,7$. Segundo a literatura, relações $\mathrm{N}: \mathrm{S}$ acima deste valor seriam um bom indicativo de deficiência de enxofre em gramíneas. Porém, em seu trabalho tal relação foi variável com a dose de nitrogênio aplicado; com doses maiores de $\mathrm{N}$ a produção não foi afetada até a relação $\mathrm{N}: \mathrm{S}$ 
$=18$. Os autores concluíram que este indicador pode levar a erros de interpretação de deficiência de $\mathrm{S}$ quando na verdade a relação $\mathrm{N}: \mathrm{S}$ se torna alta pelo excesso de nitrogênio em plantas com suficiente teor de S na M.S.

A dose de 30 a $60 \mathrm{~kg}$ de $\mathrm{S} /$ ha é indicada para o capim-colonião por MALAVOLTA et al. (1984), para ensaios em vasos. Estes autores mencionaram as relações $\mathrm{N}: \mathrm{S}$ maior que 20,P:S acima de 1 , percentagem de $\mathrm{S}$ nas folhas de 0,08 a $0,10 \%$ e nos colmos de $0,11 \%$ como sendo características de plantas deficientes desse nutriente.

MONTEIRO \& CARRIEL (1987) concluíram que doses de 30 a 40 $\mathrm{kg}$ de $\mathrm{S} /$ ha foram necessária para que o capim-colonião apresentasse um teor mínimo de enxofre entre $0,08 \%$ e $0,12 \%$ e uma relação $\mathrm{N}: \mathrm{S}$ de 13,7 no $2^{\circ}$. corte. Encontraram resposta para máxima produção na dose de $75 \mathrm{~kg}$ de $\mathrm{S} / \mathrm{ha}$.

No presente trabalho observaram-se no $2^{\circ}$. corte teores de $\mathrm{S}$ da ordem de $0,086 \%$ e $0,08 \%$ na parte aérea, relação $\mathrm{N}: \mathrm{S}$ de 17,02 e 19,71 e relação $\mathrm{P}: \mathrm{S}$ de 1,52 e 1,64 para os cultivares Vencedor e Colonião IZ-1, respectivamente. Assim, a percentagem de $\mathrm{S}$ e relação $\mathrm{N}: \mathrm{S}$ estariam dentro dos níveis obtidos por outros autores e considerados aceitáveis. Quanto à relação $\mathrm{P}: \mathrm{S}$ acima de 1 , aponta uma suposta deficiência de $\mathrm{S}$, a despeito da boa produção utilizada $\left(58,1\right.$ e $32,0 \mathrm{~kg}$ de $\mathrm{S} / \mathrm{ha}$ no $1^{\circ}$. e $2^{\circ}$. cortes, respectivamente.

Para o capim-andropogon a porcentagem de $\mathrm{S}$ foi em média $0,08 \%$ e $0,05 \%$ para o $1^{\circ}$. e $2^{\circ}$. cortes, respectivamente (Tabela 29). Efeito positivo de calagem no teor de S na M.S. desta gramínea foi observado apenas no $2^{\circ}$. corte por PAULINO et al. (1989), diferindo do presente experimento, onde não foi observado efeito dos níveis de calcário no teor de $\mathrm{S}$ em ambos os cortes. 


\subsubsection{Composição Mineral - Micronutrientes}

\subsubsection{Boro}

É bastante abordado na literatura a diminuição da disponibilidade de boro no solo com aumento do pH (MALAVOLTA, 1976; RAIJ et al., 1985; MATTOS \& COLOZZA, 1986). Porém, verificou-se efeito significativo $(\mathrm{p}<0,05)$ da aplicação de calcário no acréscimo de B na M.S. da parte aérea a partir do nível 1 , onde $\mathrm{V} \%=30,81$ e 27,84 para Colonião IZ-1, Vencedor, Centenário e Marandu no $1^{\circ}$. e $2^{\circ}$. cortes, respectivamente (Tabela 30). Efeito de "concentração" deste nutriente pode ser atribuído para o $1^{\circ}$. corte, com maior teor de B na M.S. dos capins, já que decréscimos da produção de M.S. foram observados.

Os resultados da regressão polinomial mostraram aumento linear representado pela equação $Y=20,6702+0,6647 X$ para estes cultivares no $1^{\circ}$. corte (Figura 19) e $\mathrm{Y}=10,9573+0,3180 \mathrm{X}$, no $2^{\circ}$. corte (Figura 20).

No $1^{\circ}$. corte os cultivares Vencedor, Centenário e Marandu não diferiram entre si no teor de B (Tabela 31), apresentando maior teor desse nutriente na M.S. que o cultivar Colonião IZ-1 (Tukey 5\%).

No $2^{\circ}$. corte houve aumento no teor de boro na M.S. com interação para os níveis de calcário e cultivares com diferenças no teor desse elemento da M.S. dos capins dentro dos níveis de V\%. Para o IZ_l, o teor desse nutriente aumentou com V\%= 42,07 (nível 2), não havendo mais diferença significativa até a dose mais alta do corretivo, 
segundo a equação quadrática $Y=13,9638+2,8827 X-0,3534 X^{2}$ (Figura 22); o Centenário teve seu teor de B na M.S. aumentado sc ente a partir de V\%= 57,16 (nível 3), não alterando-se mais até o último nível, apresentando equação linear $\mathrm{Y}=8,1757+0,5898 \mathrm{X}$ (Figura 22); não houve efeito da cal or de B na M.S. dos cultivares Vencedor e Marandu. Ainda no $2^{\circ}$. corte, o Coswawo IZ-1 apresentou maior teor de B na M.S., seguido pelo Vencedor e o Centenário; o cultivar Marandu apresentou o menor teor desse nutriente, porém sem diferir do Cenrano (Tabela $3 ?$ \%

No $2^{\circ}$. corte Colonião IZ-1 e Vencedor apresentaram mesmo teor de B no nível 1 com uma saturação por bases $27,84 \%$. No nível 2 até o nível 3 , com V\% de 42,07 até 57,16, o Colonião IZ-1 apresentou maior teor de B na M.S. que os demais capins. No nível 4, quando a saturação por bases atingiu $69,55 \%$, o Colonião IZ-1, Vencedor e Centenário tiveram maior teor desse nutriente na M.S.; neste nível o cultivar Marandu apresentou teor de boro igual ao Centenário. Não houve efeito significativo dos níveis de calcário no teor de B na M.S. do cultivar Marandu (Tabela 30). Fato oposto foi encontrado por PREMAZZI (1991), também no $2^{\circ}$ corte.

Para o Andropogon não houve efeito das doses do corretivo no teor desse nutriente na M.S. em ambos os cortes (Tabela 40). PAULINO et al. (1989) encontraram aumento significativo $(\mathrm{p}<0,01)$ no teor de B com a elevação da calagem, no $2^{\circ}$. corte. 
Tabela 30. Teor de boro (B) - ppm na M.S. da parte aérea dos cultivares Colonião ZZ-1, Vencedor, Centenário e Marandu no $1^{\circ}$. e $2^{\circ}$. corte (média de 4 repetições).

\begin{tabular}{|c|c|c|c|c|c|c|}
\hline \multirow{2}{*}{$\begin{array}{l}\text { Niveis } \\
\text { de } \\
\text { calcário }\end{array}$} & \multirow{2}{*}{$\begin{array}{c}\text { B } 1^{\circ} . \text { corte } \\
\text { Médias de } \\
16 \text { repet. }\end{array}$} & \multicolumn{5}{|c|}{$2^{\circ}$. corte } \\
\hline & & $\begin{array}{l}\text { Médias de } \\
16 \text { repet. }\end{array}$ & 1 & 2 & 3 & 4 \\
\hline 1 & $21 \mathrm{~b}$ & $11 \mathrm{~b}$ & $14 \mathrm{~b}$ & $11 \mathrm{a}$ & $9 \mathrm{~b}$ & 9 a \\
\hline 2 & $22 \mathrm{ab}$ & $12 \mathrm{ab}$ & $19 \mathrm{a}$ & $11 \mathrm{a}$ & $8 \mathrm{~b}$ & 9 a \\
\hline 3 & $23 a b$ & $13 \mathrm{ab}$ & $20 \mathrm{a}$ & $11 \mathrm{a}$ & $11 \mathrm{ab}$ & $9 \mathrm{a}$ \\
\hline 4 & $26 \mathrm{a}$ & $13 \mathrm{a}$ & $16 a b$ & $14 \mathrm{a}$ & $13 \mathrm{a}$ & $10 \mathrm{a}$ \\
\hline Teste F & * & * & - & - & - & - \\
\hline Reg. linear & $(0,92)^{* *}$ & $(0,99)^{* *}$ & n.s. & n.s. & $(0,82)^{* *}$ & n.s. \\
\hline Reg. quadrática & n.s. & n.s. & $(0,99)^{* *}$ & n.s. & n.s. & n.s. \\
\hline C.V. $(\%)$ & 21,20 & 17,02 & - & - & - & - \\
\hline
\end{tabular}

Teste $\mathrm{F}$ para a interação niveis $\mathrm{x}$ cultivares no $2^{\circ}$. corte: *

Niveis de significância: ** $1 \%$; $5 \%$; n.s. não significativo.

Médias seguidas pela mesma letra, dentro de cada coluna, não difierem entre si pelo teste de Tukey $5 \%$.

Os valores entre parênteses indicam o coeficiente de determinação $R^{2}$ para a equação.

Tabela 31. Teor de boro (B) (ppm) na M.S. da parte aérea entre os cultivares Colonião $1 Z-1$, Vencedor, Centenário e Marandu no $1^{\circ}$. e $2^{\circ}$. corte (média de 4 repetições).

Niveis de calagem

B $1^{\circ}$, corte B $2^{\circ}$. corte

Cultivares

\begin{tabular}{ccccccc}
\cline { 4 - 5 } & & & & \\
Médias de & & Médias de & 1 & 2 & 3 & 4 \\
16 repet. & 16 repet. & & & &
\end{tabular}

$\begin{array}{lcccccc}\text { Colonião IZ-1 } & 17 \mathrm{~b} & 17 \mathrm{a} & 14 \mathrm{a} & 19 \mathrm{a} & 20 \mathrm{a} & 16 \mathrm{a} \\ \text { Vencedor } & 27 \mathrm{a} & 12 \mathrm{~b} & 11 \mathrm{ab} & 11 \mathrm{~b} & 11 \mathrm{~b} & 14 \mathrm{a} \\ \text { Centenário } & 25 \mathrm{a} & 10 \mathrm{bc} & 9 \mathrm{~b} & 8 \mathrm{~b} & 11 \mathrm{~b} & 13 \mathrm{ab} \\ \text { Marandu } & 23 \mathrm{a} & 9 \mathrm{c} & 9 \mathrm{~b} & 9 \mathrm{~b} & 9 \mathrm{~b} & 10 \mathrm{~b} \\ & & & & & & \\ \text { Teste F } & * * & 17,02 & - & - & - & - \\ \text { C.V. (\%) } & 21,20 & & & -\end{array}$

Teste $\mathrm{F}$ para a interação niveis $\mathrm{x}$ cultivares no $2^{\circ}$. corte: *

Niveis de significância: ${ }^{* *} 1 \%$; ${ }^{*} 5 \%$; n.s. não significativo.

Médias seguidas pela mesma letra, dentro de cada coluna, não diferem entre si pelo teste de Tukey $5 \%$. 

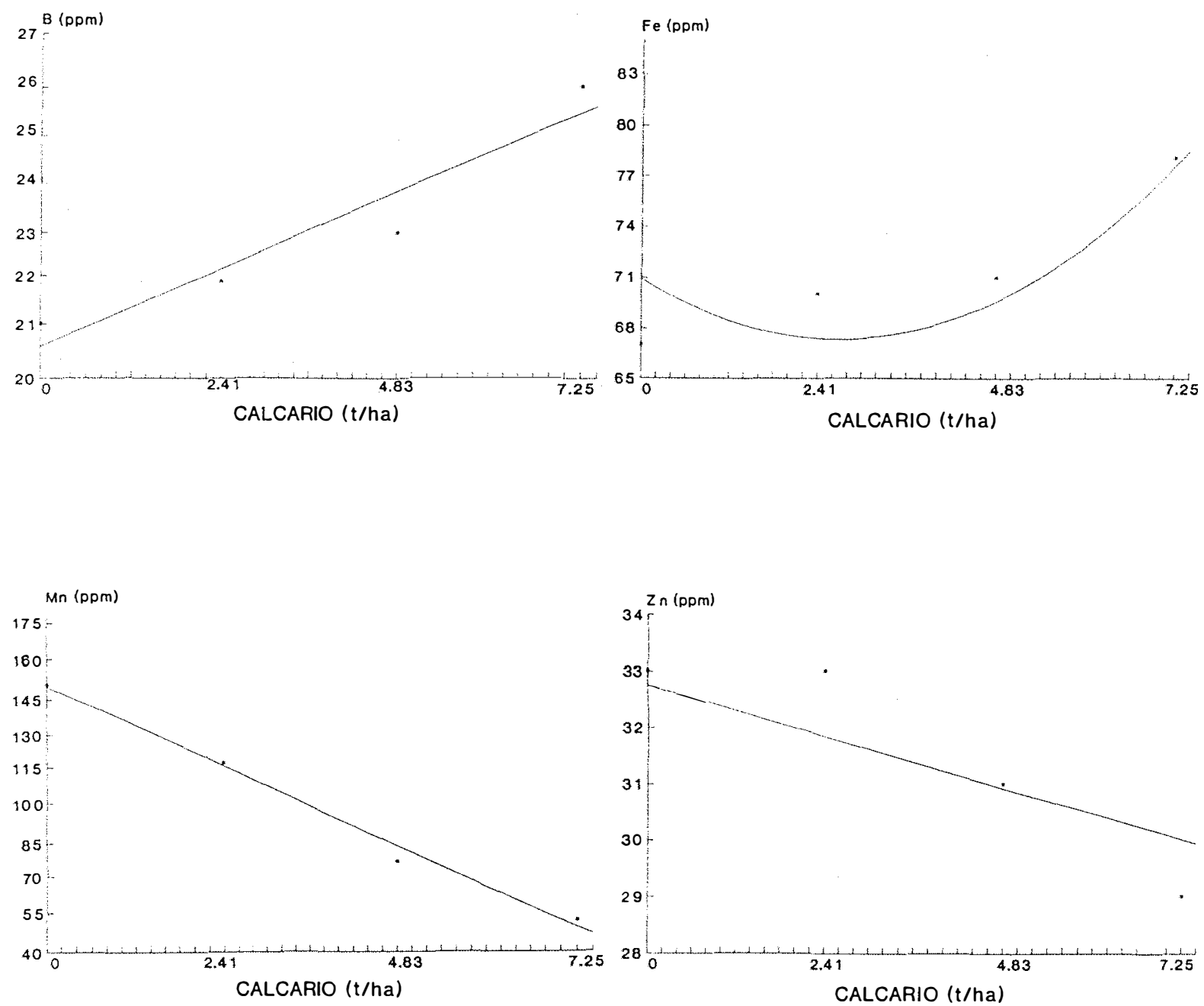

Figura 19. Efeito dos níveis de calcário nos teores de $\mathrm{B}, \mathrm{Fe}, \mathrm{Mn}$ e $\mathrm{Zn}$ na matéria seca da parte aérea nos cultivares Colonião IZ-1, Vencedor, Centenário e Marandu no $1^{\circ}$. corte. 

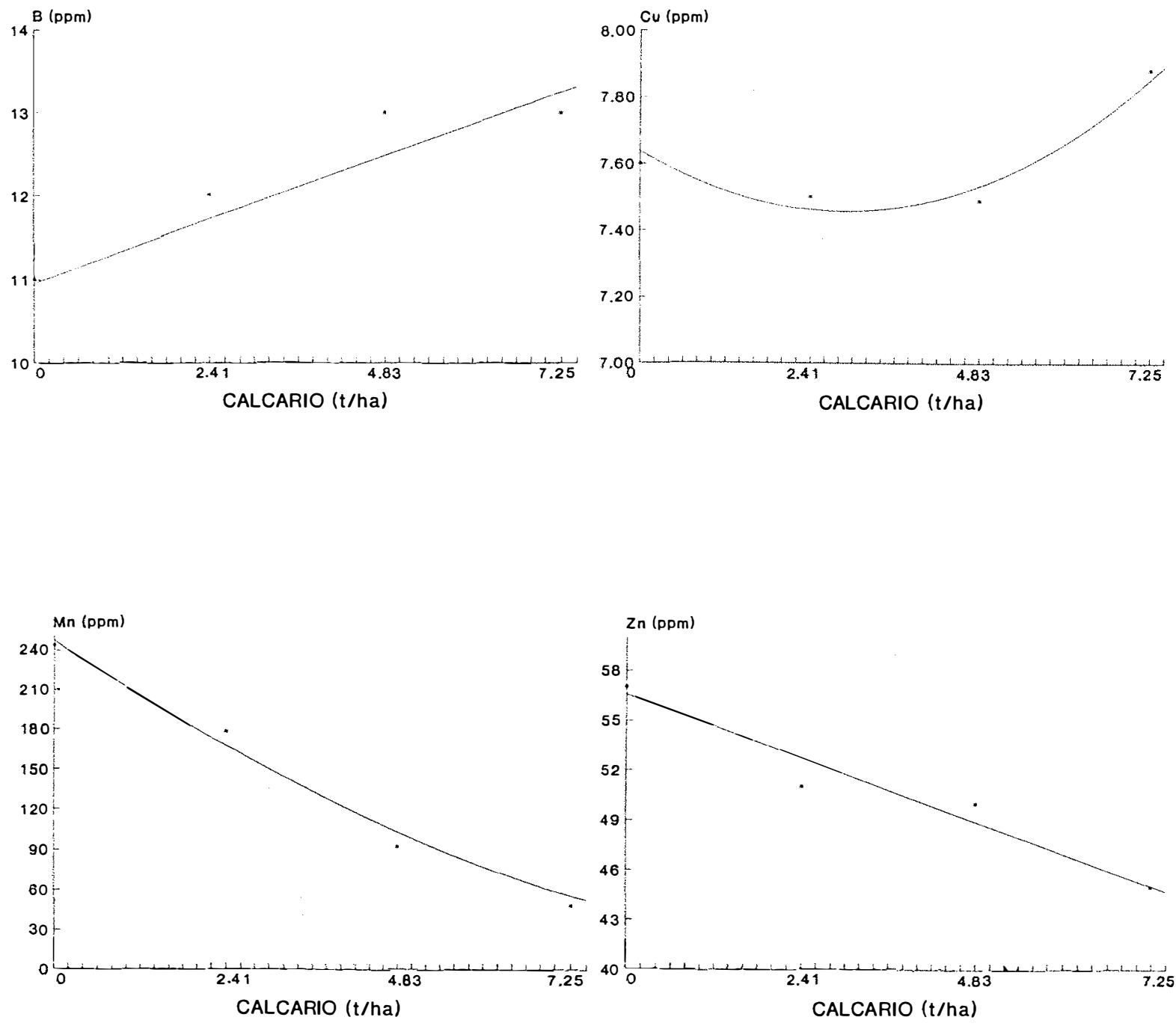

Figura 20. Efeito dos níveis de calcário nos teores de $\mathrm{B}, \mathrm{Cu}, \mathrm{Mn}$ e $\mathrm{Zn}$ na matéria seca da parte aérea dos cultivares Colonião IZ-1, Vencedor, Centenário e Marandu no $2^{\circ}$. corte. 


\subsubsection{Cobre}

No $1^{\circ}$. corte não houve efeito da calagem no teor de $\mathrm{Cu}$ na M.S. das gramíneas (Tabela 32). No entanto, esse teor variou significativamente $(p<0,01)$ entre os diversos cultivares estudados. Os teores foram mais altos para os cultivares Centenário, seguidos pelo Marandu, Vencedor e Colonião IZ-1, respectivamente (Tukey 5\%) (Tabela 33). No $2^{\circ}$. corte houve efeito signifícativo dos níveis de calcário nos cultivares Colonião IZ-1, Vencedor, Centenário e Marandu, porém estas diferenças não foram detectadas pelo teste Tukey $5 \%$. O efeito foi quadrático representado pela equação $\mathrm{Y}=7,6375-0,1241 \mathrm{X}$ $+0,0214 X^{2}$, como mostra a Figura 20

Houve efeito dos níveis de calagem para o cultivar Vencedor, cujo teor de $\mathrm{Cu}$ na M.S. diminuiu no nível 3, com V\% = 57,03, aumentando a seguir com $\mathrm{V} \%$ $=68,33$, último nível de calcário segundo a equação $\mathrm{Y}=8,8995-0,0931 \mathrm{X}\left(\mathrm{R}^{2}=0,46\right)$. Para os cultivares Centenário e Marandu não houve diferença detectada pelo teste de Tukey $5 \%$. Porém as equações de regressão foram $\mathrm{Y}=6,3752+0,1035 \mathrm{X}\left(\mathrm{R}^{2}=0,83\right)$ e $\mathrm{Y}=$ $9,5254+0,1138 X\left(R^{2}=0,89\right)$, respectivamente.

O teor de cobre variou significativamente entre os cultivares nos níveis de calcário (interação significativa) (Tabela 33). Assim, no nível 1 com V\%=30,81 o Marandu e Vencedor apresentaram igual teor de $\mathrm{Cu}$, porém diferentes do Centenário e do Colonião IZ-1, este último apresentando menor teor de $\mathrm{Cu}$ na M.S. (Tukey 5\%). Nos demais níveis de calcário o teor desse nutriente na M.S. foi maior para o Marandu, seguindo-se em ordem decrescente o Vencedor, Centenário e IZ-1 (Tukey 5\%).. 
Tabela 32. Teor de cobre (Cu) (ppm) na M.S. da parte aérea, entre o sniveis de calcário, dos cultivares Colonião IZ-1, Vencedor, Centenário e Marandu no $1^{\circ}$. e $2^{\circ}$. corte (média de 4 repetiçōes).

\begin{tabular}{|c|c|c|c|c|c|c|}
\hline \multirow{2}{*}{$\begin{array}{l}\text { Níveis } \\
\text { de } \\
\text { calcário }\end{array}$} & \multirow{2}{*}{$\begin{array}{c}\mathrm{Cu} \quad 1^{\circ} \text {. corte } \\
\text { Médias de } \\
16 \text { repet. }\end{array}$} & \multicolumn{5}{|c|}{$2^{\circ}$. corte } \\
\hline & & $\begin{array}{l}\text { Médias de } \\
16 \text { repet. }\end{array}$ & 1 & 2 & 3 & 4 \\
\hline 1 & $11 \mathrm{a}$ & $8 \mathrm{a}$ & $5 a$ & 9 a & $6 a$ & $9 \mathrm{a}$ \\
\hline 2 & $10 \mathrm{a}$ & $7 \mathrm{a}$ & $5 a$ & $9 \mathrm{ab}$ & $6 a$ & $10 \mathrm{a}$ \\
\hline 3 & $10 \mathrm{a}$ & $7 \mathrm{a}$ & $5 a$ & $8 \mathrm{~b}$ & $7 a$ & $10 \mathrm{a}$ \\
\hline 4 & $10 \mathrm{a}$ & $8 \mathrm{a}$ & $5 a$ & $8 \mathrm{ab}$ & $10 \mathrm{a}$ & \\
\hline Teste F & n.s. & $*$ & . & - & - & - \\
\hline Reg. linear & n.s. & n.s. & n.s. & $(0,46)^{*}$ & $(0,83)^{*}$ & $(0,89)^{*}$ \\
\hline Reg. quadrátrica & n.s. & $(0,97)^{*}$ & $(1,00)^{*}$ & n.s. & n.s. & n.s. \\
\hline C.V. $(\%)$ & 5.40 & 5.49 & - & - & - & - \\
\hline
\end{tabular}

Teste $\mathrm{F}$ para a interação niveis $\mathrm{x}$ cultivares no $2^{\circ}$. corte: ${ }^{*}$

Niveis de significància: ${ }^{* *} 1 \%: * 5 \%$; n.s. não significativo.

Médias seguidas pela mesma letra, dentro de cada coluna, não diferem entre si pelo teste de Tukey $5 \%$.

Os valores entre parênteses indicam o coeficiente de determinação $R^{2}$ para a equação.

Tabela 33. Teor de cobre (Cu) (ppm) na M.S. da parte aérea entre os cultivares Colonião $\mathrm{Z}-1$, Vencedor, Centenário e Marandu no $1^{\circ}$. e $2^{\circ}$. corte (média de 4 repetições).

Níveis de calagem

$\mathrm{Cu} 1^{\circ}$. corte $\mathrm{Cu} 2^{\circ}$. corte

Cultivares

\begin{tabular}{|c|c|c|c|c|c|}
\hline $\begin{array}{l}\text { Médias de } \\
16 \text { repet. }\end{array}$ & $\begin{array}{l}\text { Médias de } \\
16 \text { repet. }\end{array}$ & 1 & 2 & 3 & 4 \\
\hline
\end{tabular}

\begin{tabular}{|c|c|c|c|c|c|c|}
\hline Colonião [Z-1 & $6 \mathrm{~d}$ & $5 \mathrm{~d}$ & $5 \mathrm{c}$ & $5 \mathrm{~d}$ & $5 d$ & $5 \mathrm{~d}$ \\
\hline Vencedor & $10 \mathrm{c}$ & $9 \mathrm{~b}$ & 9 a & $9 \mathrm{~b}$ & $8 \mathrm{~b}$ & $8 \mathrm{~b}$ \\
\hline Centenário & $14 \mathrm{a}$ & $7 \mathrm{c}$ & $6 \mathrm{~b}$ & $6 \mathrm{c}$ & $7 \mathrm{c}$ & $7 \mathrm{c}$ \\
\hline Marandu & $11 \mathrm{~b}$ & $10 \mathrm{a}$ & 9 a & $10 \mathrm{a}$ & $10 \mathrm{a}$ & $10 \mathrm{a}$ \\
\hline Teste F & $* *$ & ** & - & - & - & - \\
\hline C.V. $(\%)$ & 5,40 & 5,49 & - & - & - & - \\
\hline
\end{tabular}

Teste $\mathrm{F}$ p ara a interação niveis $\mathrm{x}$ cultivares no $2^{\circ}$. corte: ${ }^{*}$

Níveis de significància: ${ }^{* *} 1 \% ; * 5 \%$; n.s. não significativo.

Médias seguidas pela mesma letra, dentro de cada coluna. não diferem entre si pelo teste de Tukey $5 \%$. 
Tabela 34. Teor de ferro (Fe) (ppm) na M.S. da parte aérea dos cultivares Colonião IZ-1, Vencedor, Centenário e Marandu, no $1^{\circ}$. e $2^{\circ}$. corte (médias de 4 repetições).

\begin{tabular}{lcc} 
Niveis de calcário & $\mathrm{Fe} 1^{\circ}$. corte & $2^{\circ}$. corte \\
\hline & $71 \mathrm{ab}$ & $83 \mathrm{a}$ \\
2 & $67 \mathrm{~b}$ & $99 \mathrm{a}$ \\
3 & $70 \mathrm{~b}$ & $86 \mathrm{a}$ \\
4 & $78 \mathrm{a}$ & $93 \mathrm{a}$ \\
& & n.s. \\
Teste F & $* *$ & n.s. \\
Reg. quadrática & $(1,00)^{* *}$ & 25,80 \\
C.V. $(\%)$ & 11.50 & \\
\hline
\end{tabular}

Niveis de significância: $* * 1 \%: * 5 \%$ : n.s. não significativo.

Médias seguidas pela mesma letra. dentro de cada coluna, não diferem entre si pelo teste de Tukey $5 \%$.

Os valores entre parênteses indicam o coeficiente de determinação $R^{2}$ para a equação.

Tabela 35. Teor de ferro $(\mathrm{Fe})(\mathrm{ppm})$ na M.S. da parte aérea entre os cultivares Colonião IZ-1. Vencedor. Centenário e Marandu. no ${ }^{\circ}$. e $2^{\circ}$. corte (médias de 16 repetições).

\begin{tabular}{lcc} 
Cultivares & Fe $1^{\circ}$. corte & $2^{\circ}$. corte \\
\hline Colonião IZ-1 & $60 \mathrm{c}$ & $75 \mathrm{~b}$ \\
Vencedor & $74 \mathrm{ab}$ & $82 \mathrm{~b}$ \\
Centenário & $71 \mathrm{~b}$ & $83 \mathrm{~b}$ \\
Marandu & $81 \mathrm{a}$ & $121 \mathrm{a}$ \\
& & $* *$ \\
Teste F & $* *$ & 25,80 \\
C.V. $(\%)$ & 11,50 & \\
\hline
\end{tabular}

Niveis de significância: ${ }^{* *} 1 \% ; * 5 \%$; n.s. não significativo.

Médias seguidas pela mesma letra. dentro de cada coluna, não diferem entre si pelo teste de Tukey $5 \%$. 

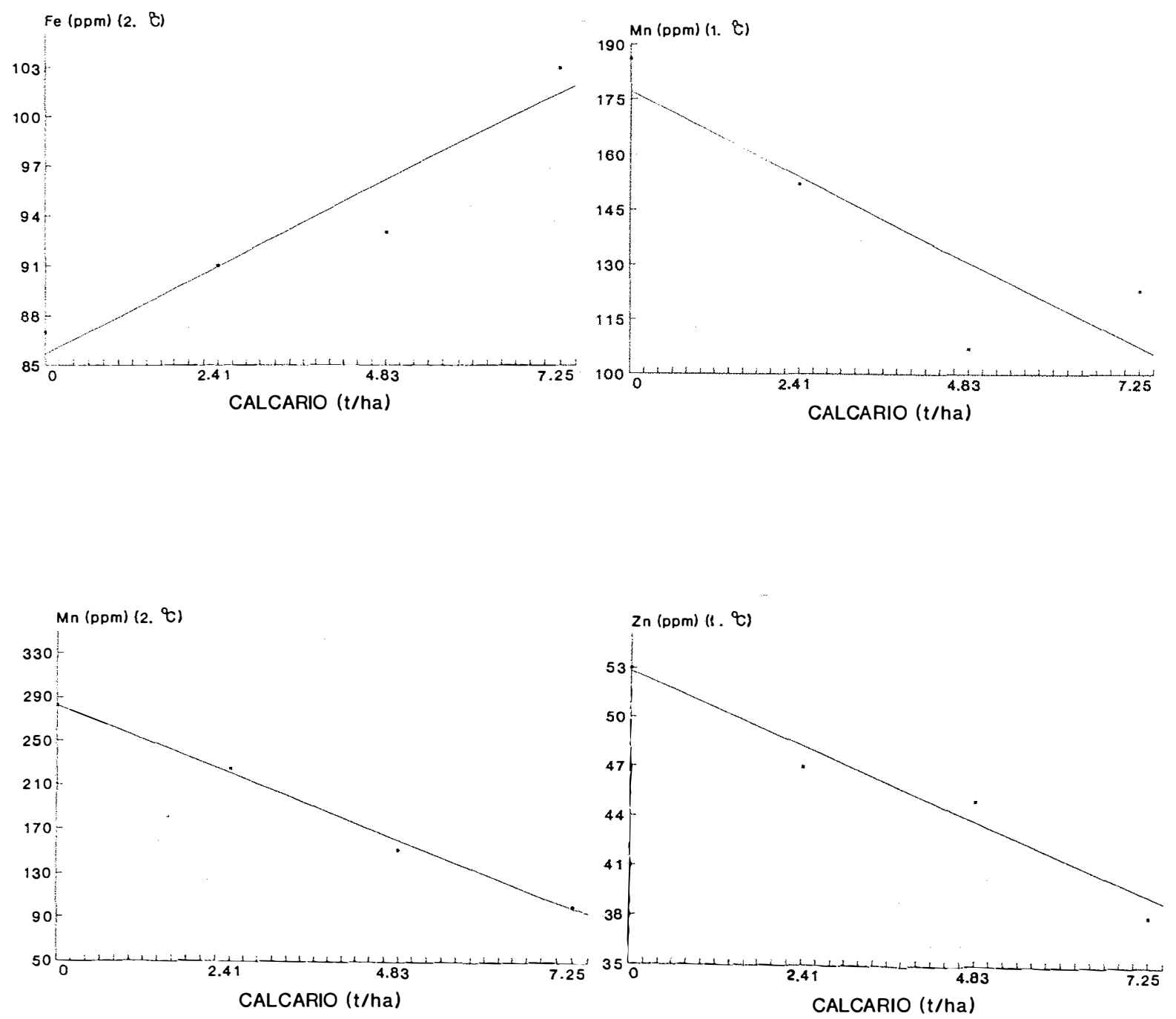

Figura 21. Efeito dos níveis de calcário nos teores de $\mathrm{Fe}\left(2^{\circ}\right.$. corte), $\mathrm{Mn}\left(1^{\circ}\right.$. e $2^{\circ}$. corte) e $\mathrm{Zn}\left(1^{\circ}\right.$. corte) na matéria seeca da parte aérea do capim-andropogon. 

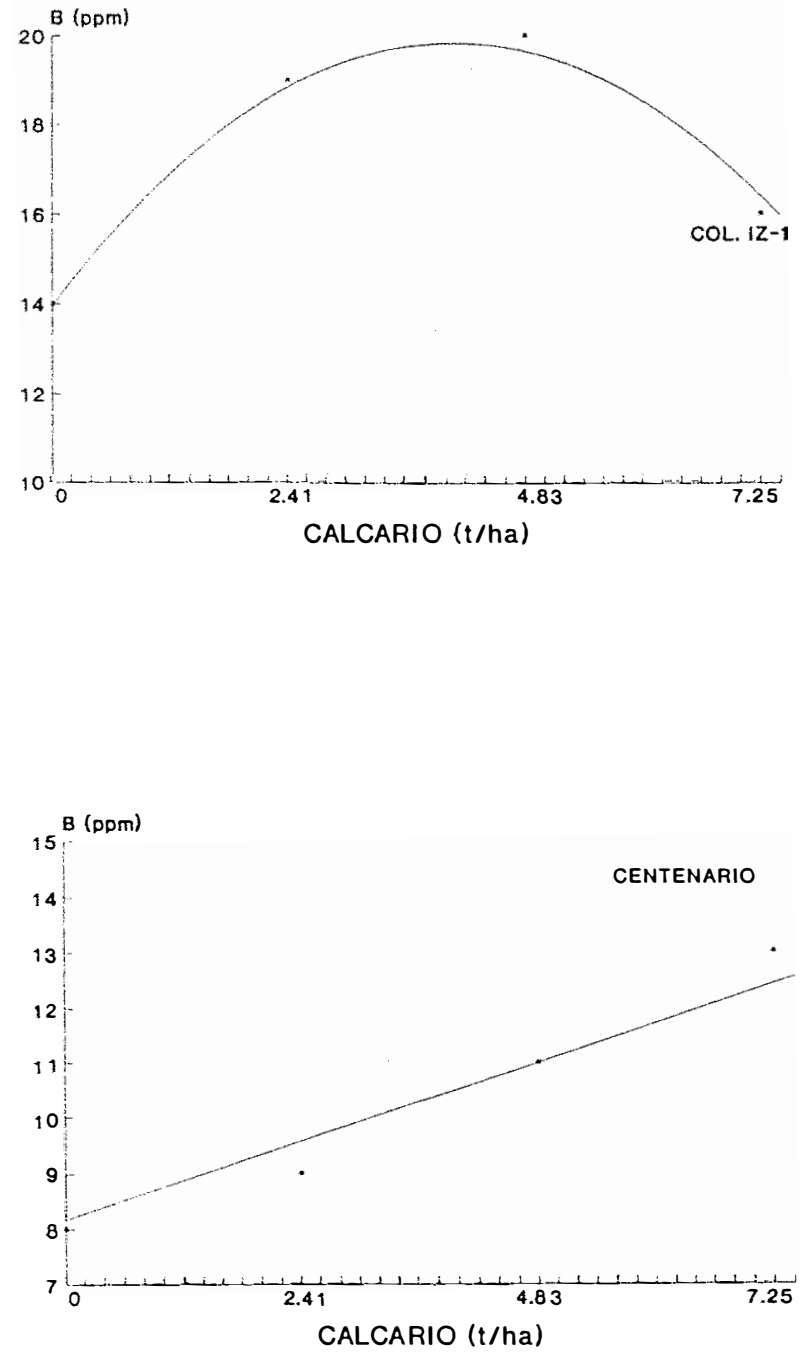

Figura 22. Efeito dos níveis de calcário no teor de B na matéria seca da parte aérea dos cultivares Colonião IZ-1 e Centenário no $2^{\circ}$. corte. 
Para o Andropogon não foi observado efeito significativo dos níveis do corretivo no teor desse elemento na M.S., em ambos os cortes (Tabela 40).

\subsubsection{Fenvo}

Observou-se resposta altamente significativa $(\mathrm{p}<0,01)$ nos teores de Fe com a elevação dos níveis de calcário para a média dos cultivares Colonião IZ-1, Vencedor, Centenário e Marandu no $1^{\circ}$. corte (Tabela 34). O teor de Fe não diferiu estatisticamente até o nível $3, \mathrm{~V} \%=57,03$, aumentando em seguida, quando $\mathrm{V} \%$ passou para 68,83 , representado pela equação quadrática $Y=90,7373-2,2863 X+0,5001 X^{2}$, como mostra a Figura 19. Houve diferença significativa $(p<0,01)$ do teor desse elemento entre os cultivares, onde Marandu, Vencedor e Centenário apresentaram maior teor de Fe que o cultivar Colonião IZ-1 (Tabela 35).

No $2^{\circ}$. corte não houve efeito significativo $(p>0,05)$ dos níveis de calcário no teor de Fe na M.S. Porém, observou-se diferenças significativas $(p<0,01)$ entre os cultivares. A Brachiaria brizantha cv. Marandu apresentou maior teor de Fe na M.S. (Tabela 35). Os níveis desse nutriente na M.S. dos cultivares de Panicum não diferiram entre si e se encontram levemente abaixo da média sugerida por GALLO et al. (1974), porém dentro da faixa de dispersão.

Os tratamentos não alteraram significativamente o teor de Fe na M.S. do capim Andropogon no $1^{\circ}$. e $2^{\circ}$. cortes (Tabela 40). Porém, a regressão polinomial mostrou aumento linear no $2^{\circ}$. corte, dado pela equação $\mathrm{Y}=85,6802+2,1932 \mathrm{X}$ (Figura 21). 


\subsubsection{Manganês}

Os teores de manganês na parte aérea para todos os cultivares sofreram decréscimos altamente significativos no $1^{\circ}$. e $2^{\circ}$. cortes com os níveis de calcário (Tukey 1\%), como mostra a Tabela 36.

Houve diferenças nos teores desse elemento entre os cultivares ( $p<$ $0,01)$ e interação significativa $(p<0,01)$, com diferentes comportamentos dos capins dentro de cada nível de calcário empregado tanto no $1^{\circ}$. como no $2^{\circ}$. corte (Tabela 37 ).

No $1^{\circ}$. corte, o Colonião IZ-1 apresentou decréscimo no teor de $\mathrm{Mn}$ a partir do nível 3 de calcário, com V\%=57,03; o Vencedor a partir de 45,81 (nível 2), com diminuição gradativa e significativa (Tukey 5\%) até o nível mais alto de calcário; o Centenário também a partir de 45,81, não havendo diferença entre os níveis 2 e 3 , tornando a decrescer no último nível de calcário $\mathrm{V} \%=68,83$; o Marandu apresentou decréscimo a partir do nível 1 com $\mathrm{V} \%=57,03$, não havendo diferença no teor desse elemento com a dose mais elevada do corretivo (Tabela 36). A análise de regressão polinomial apresentou decréscimo linear para o Colonião IZ-1 segundo a equação $\mathrm{Y}=132,3185-12,3723 \mathrm{X}$; Y $=205,5868-20,2621 \mathrm{X}$ para o Vencedor; $\mathrm{Y}=119,8654-10,1250 \mathrm{X}$ para o Centenário e $\mathrm{Y}=143,4574-12,8247 \mathrm{X}$ para o cultivar Marandu, como mostra as Figuras 23 e 24.

Nos níveis de calcário 1 e 2 o Vencedor apresentou maior teor de $\mathrm{Mn}$, se igualando aos demais capins no $3^{\circ}$. nível, com exceção do Marandu. $\mathrm{Na}$ dose mais elevada de calcário todos os cultivares não diferiram entre si significativamente quanto ao teor de manganês (Tabela 37). 
No $2^{\circ}$. corte o IZ-1, Vencedor e Centenário apresentaram decréscimos no teor de Mn até o nível 3, com $\mathrm{V} \%=57,16$; já o Marandu diminuiu gradativamente o teor desse elemento com o aumento da calagem, a partir de $\mathrm{V} \%=42,07$ (nível 2 de calcário). A análise de regressão apresentou decréscimo linear para o Colonião IZ-1 dado pela equação $\mathrm{Y}=268,8927-29,1284 \mathrm{X}$; decréscimo quadrático para o Vencedor, representado pela equação $Y=304,4890-60,8503 X+3,6569 X^{2}$; decréscimo linear para o Centenário, dado pela equação $\mathrm{Y}=179,9902-19,4245 \mathrm{X}$ e decréscimo linear para o cultivar Marandu, onde $\mathrm{Y}=224,1021-22,6817 \mathrm{X}$ (Figuras 23 e 24).

O teor de Mn entre os cultivares IZ-1 e Vencedor não diferiu nos níveis 1 e 2 de calcário, e foi igual entre todos os capins nos dois níveis mais elevados de calagem, cujos valores de V\% atingidos foram 57,16 e 69,5 , respectivamente.

Para o capim-andropogon não houve efeito significativo no nível de calcário sobre o teor de manganês no $1^{\circ}$. corte. Porém a regressão polinomial apresentou equação linear decrescente, dada por $\mathrm{Y}=117,2101-9,6681 \mathrm{X}$ (Tabela 40). Houve diminuição signifícativa $(\mathrm{p}<0,01)$ no $2^{\circ}$. corte, dado pela equação $\mathrm{Y}=282,5239$ 25,3517X (Tabela 40), corroborando com resultados obtidos por PAULINO et al. (1989), trabalhando com esta gramínea.

Decréscimo do teor de Mn na parte aérea de gramíneas com a adição de calcário ao solo foi relatado por ABRUÑA et al. (1964), PAULINO et al. (1989) e PREMAZZI (1991) e explicados como devidos à redução na disponibilidade dos micronutrientes (boro, ferro, manganês e zinco) no solo com o aumento do $\mathrm{pH}$. 
Tabela 36. Teor de manganês $(\mathrm{Mn})(\mathrm{ppm})$ na M.S. da parte aérea dos cultivares Colonião IZ-1, Vencedor, Centenário e Marandu, no $1^{\circ}$. e $\quad 2^{\circ}$. corte (médias de 4 repetições).

\begin{tabular}{|c|c|c|c|c|c|c|c|c|c|c|c|}
\hline \multirow{2}{*}{$\begin{array}{l}\text { Níveis } \\
\text { de } \\
\text { calcário }\end{array}$} & \multicolumn{5}{|c|}{$1^{\circ}$. corte } & \multicolumn{5}{|c|}{$2^{\circ}$. corte } & \\
\hline & $\begin{array}{l}\text { Médias } \\
16 \text { repet. }\end{array}$ & $\begin{array}{l}\text { Col. } \\
\text { IZ-I }\end{array}$ & $\begin{array}{c}\text { Vence- } \\
\text { dor }\end{array}$ & $\begin{array}{l}\text { Cente- } \\
\text { nário }\end{array}$ & $\begin{array}{l}\text { Maran- } \\
\text { du }\end{array}$ & $\begin{array}{l}\text { Médias } \\
16 \text { repet. }\end{array}$ & $\begin{array}{l}\text { Col. } \\
\text { IZ-1 }\end{array}$ & $\begin{array}{c}\text { Vence- } \\
\text { dor }\end{array}$ & $\begin{array}{l}\text { Cente- } \\
\text { nário }\end{array}$ & \multicolumn{2}{|l|}{$\begin{array}{l}\text { Maran- } \\
\text { du }\end{array}$} \\
\hline 1 & $151 \mathrm{a}$ & $128 \mathrm{a}$ & $207 a$ & $123 a$ & $147 a$ & $243 a$ & $265 a$ & $300 a$ & $181 \mathrm{a}$ & $228 \mathrm{a}$ & \\
\hline 2 & $118 \mathrm{~b}$ & $109 a$ & $160 b$ & $90 \mathrm{~b}$ & $114 b$ & $178 b$ & $216 b$ & $192 b$ & $135 b$ & $168 b$ & \\
\hline 3 & $77 c$ & $73 b$ & $95 c$ & $72 \mathrm{bc}$ & $69 b c$ & $93 c$ & $105 c$ & $82 c$ & $78 c$ & $106 c$ & \\
\hline 4 & $53 d$ & $40 c$ & $66 d$ & $47 c$ & $58 \mathrm{c}$ & $59 d$ & $67 c$ & $60 c$ & $44 c$ & $66 d$ & \\
\hline Teste F & $* *$ & - & - & - & - & $* *$ & - & - & - & - & \\
\hline Reg. linear & $(0,99)^{* *}$ & $(0,98)^{*}$ & $(0,98)^{* *}$ & $(0,98)^{* *}$ & $(0,95)^{* *}$ & $* *$ & $(0,96)^{* *}$ & $* *$ & $(0,99)^{* *}$ & $(0,99)^{* *}$ & \\
\hline Reg. quadr. & n.s. & n.s. & n.s. & n.s. & n.s. & $(0,99)^{* *}$ & n.s. & $(0,99)^{* *}$ & n.s. & n.s. & \\
\hline C.V. $(\%)$ & 14,06 & - & - & - & - & 14,10 & - & - & - & - & \\
\hline
\end{tabular}

Teste $\mathrm{F}$ para a interação niveis $\mathrm{x}$ cultivares: **

Níveis de significância: ** $1 \%$; 5\%: n.s. não significativo.

Médias seguidas pela mesma letra, dentro de cada coluna, não difierem entre si pelo teste de Tukey $5 \%$.

Os valores entre parênteses indicam o coeficiente de determinação $R^{2}$ para a equação.

Tabela 37. Teor de manganês ( $M$ ńn) (ppm) na M.S. da parte aérea entre os cultivares Colonião IZ-1, Vencedor, Centenário e Marandu, no $1^{\circ}$. e $2^{\circ}$. corte (médias de 4 repetições).

\begin{tabular}{|c|c|c|c|c|c|c|c|c|c|c|}
\hline \multirow{3}{*}{ Cultivares } & \multicolumn{9}{|c|}{ Niveis de calagem } & \\
\hline & \multicolumn{5}{|c|}{ Mn $\quad 1^{\circ}$. corte } & \multicolumn{2}{|r|}{$\mathrm{Mn}$} & \multicolumn{2}{|c|}{$2^{\circ}$. corte } & \multirow[b]{2}{*}{4} \\
\hline & $\begin{array}{l}\text { Médias } \\
16 \text { repet. }\end{array}$ & 1 & 2 & 3 & 4 & $\begin{array}{l}\text { Médias } \\
16 \text { repet. }\end{array}$ & 1 & 2 & 3 & \\
\hline Col. IZ-1 & $87 \mathrm{bc}$ & $128 \mathrm{~b}$ & $109 \mathrm{~b}$ & $73 a b$ & $40 \mathrm{a}$ & $163 a$ & $265 \mathrm{ab}$ & $216 a$ & $105 \mathrm{a}$ & $67 a$ \\
\hline Vencedor & $132 \mathrm{a}$ & $207 a$ & $160 \mathrm{a}$ & $95 a$ & $60 \mathrm{a}$ & $159 \mathrm{ab}$ & $300 a$ & $192 \mathrm{ab}$ & $82 a$ & $60 \mathrm{a}$ \\
\hline Centenário & $83 c$ & $123 b$ & $90 \mathrm{~b}$ & 72ab & $47 a$ & $110 \mathrm{c}$ & $181 \mathrm{c}$ & $135 \mathrm{c}$ & $78 \mathrm{a}$ & $44 a$ \\
\hline Marandu & $97 b$ & $147 b$ & $114 \mathrm{~b}$ & $69 b$ & $58 \mathrm{a}$ & $142 b$ & $228 b$ & $168 \mathrm{bc}$ & $106 a$ & $66 \mathrm{a}$ \\
\hline Teste F & $* *$ & - & - & - & - & $* *$ & $=$ & - & - & - \\
\hline C.V. $(\%)$ & 14,06 & - & - & - & - & 14,10 & - & - & - & - \\
\hline
\end{tabular}

Teste $\mathrm{F}$ para a interação niveis $\mathrm{x}$ cultivares: ${ }^{* *}$

Níveis de significància: $* * 1 \% ; * 5 \%$; n.s. não significativo.

Médias seguidas pela mesma letra, dentro de cada coluna, não difierem entre si pelo teste de Tukey $5 \%$. 

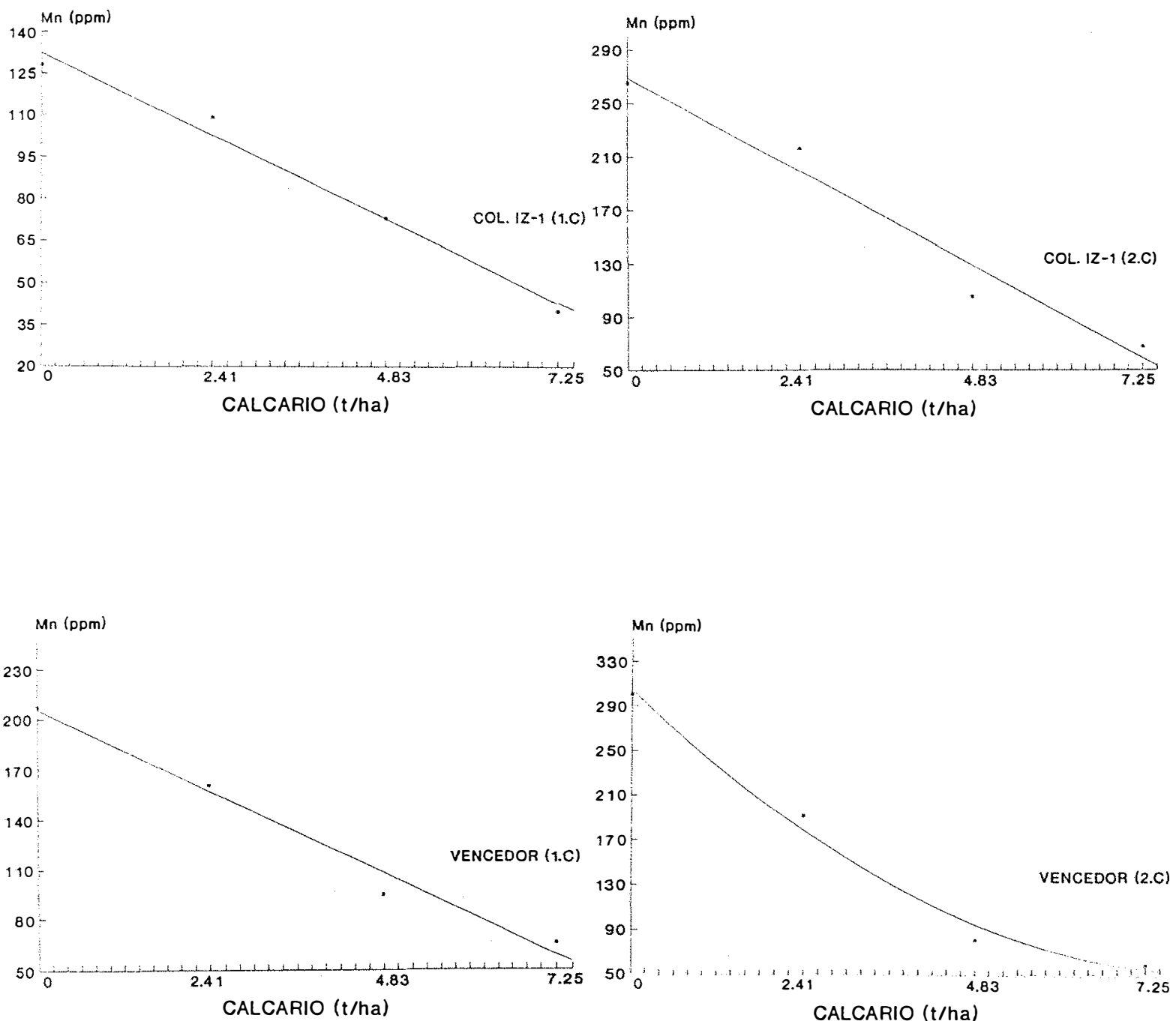

Figura 23. Efeito dos níveis de calcário nos teores de Mn na matéria seca da parte aérea dos cultivares Colonião IZ-1 e Vencedor no $1^{\circ}$. e $2^{\circ}$. corte 

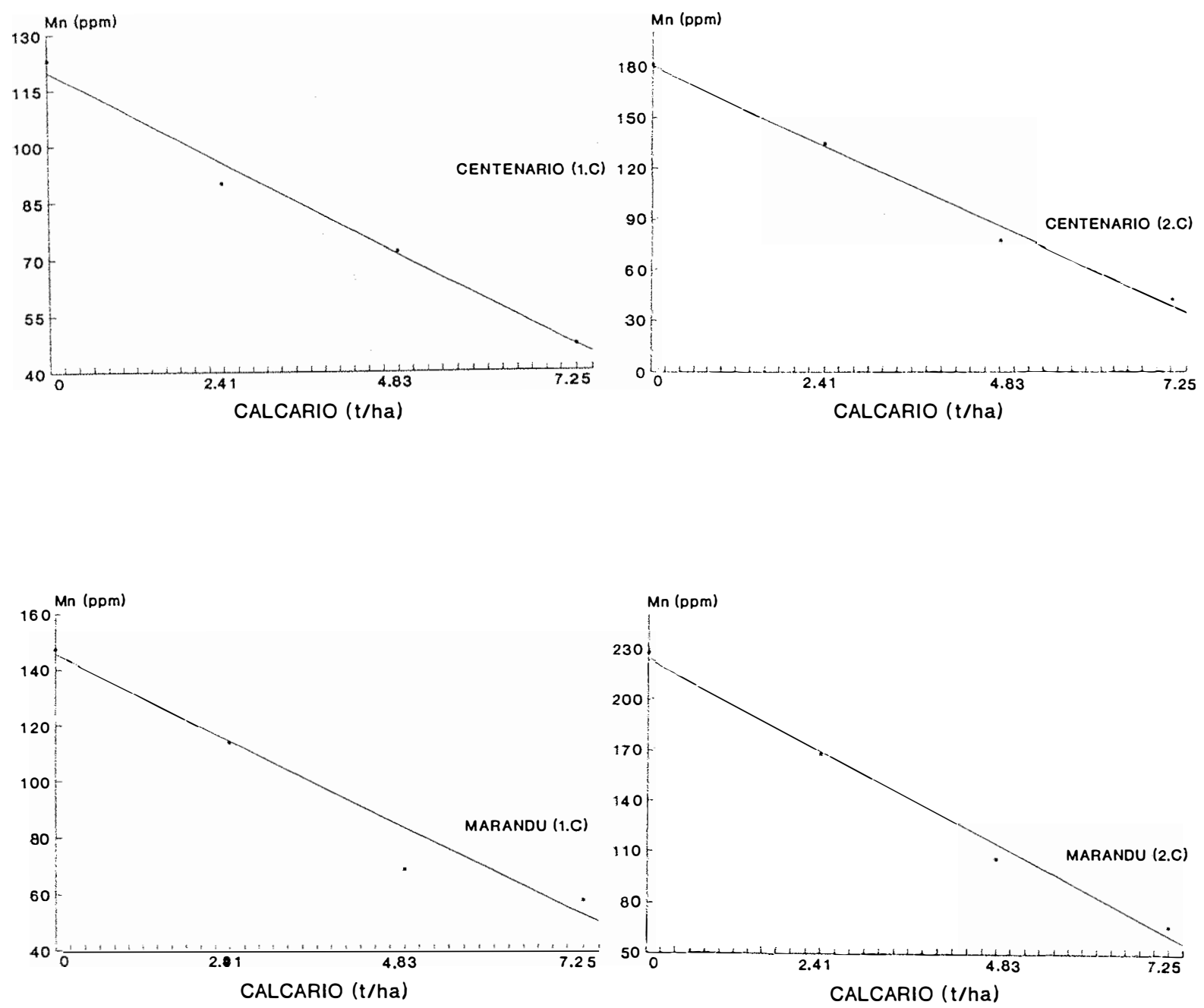

Figura 24. Efeito dos níveis de calcário nos teores de Mn na matéria seca da parte aérea dos cultivares Centenário e Marandu no $1^{\circ}$. e $2^{\circ}$. corte. 


\subsubsection{Zinco}

Pela Tabela 38 observa-se que o teor de $\mathrm{Zn}$ na M.S. diminuiu com a aplicação do calcário no $1^{\circ}$. corte, para o Colonião IZ-1 a partir de $\mathrm{V} \%=57,03$ (nível 3), para o Centenário houve diminuição no nível 2 com $45,81 \%$ seguido de elevação quando a saturação por bases passou para 57,03 (nível 3 ) e nova queda com $68,83 \%$ no nível 4

Para o Vencedor e Marandu não houve efeito significativo do aumento da calagem e no teor de $\mathrm{Zn}$ na M.S., porém com tendência a diminuir para o cultivar Marandu no $1^{\circ}$. corte. Esta tendência também foi apontada por PREMAZZI (1991). A análise de regressão polinomial apresentou diminuição quadrática para o Colonião IZ-1, dado pela equação $\mathrm{Y}=28,6252+1,3956 \mathrm{X}-0,2781 \mathrm{X}^{2}$ e diminuição linear para 0 Centenário, apresentado pela equação $\mathrm{Y}=34,9715-0,6305 \mathrm{X}$, ilustrado na Figura 25.

Notou-se diferença altamente significativa para o teor de $\mathrm{Zn}$ entre os cultivares e significativo para a interacão dos níveis e cultivares, no $1^{\circ}$. corte (Tabela 39 ). Assim, dentro dos níveis de calcário utilizados houveram comportamentos diferentes dos cultivares quanto ao teor de $\mathrm{Zn}$ na M.S.

No nível 1 com $V \%=30,81$, os cultivares Marandu e Centenario apresentaram maior teor de $\mathrm{Zn}$ na M.S., seguidos pelos outros dois cultivares IZ-1 e Vencedor (Tabela 38). Com $\mathrm{V} \%=45,81$ (nível 2) o cultivar Marandu apresentou maior teor de $\mathrm{Zn}$, seguido pelos cultivares Centenário e IZ-1, que não diferiram entre si. O teor mais baixo de $\mathrm{Zn}$ foi apresentado pelo Vencedor. A partir do nível 3, com $\mathrm{V} \%=57,03$ o 
cultivar Marandu apresentou maior teor de $\mathrm{Zn}$, seguido pelo Centenário. O teor mais baixo deste elemento foi encontrado nos cultivares IZ-1 e Vencedor.

No $2^{\circ}$. corte foi observado efeito do aumento de calcário na diminuição do teor de $\mathrm{Zn}$ a partir do nível 3, com 57,16 (Tabela 38). A equação de regressão apresentou decréscimo linear, dado pela equação $Y=56,5753$ - 1,5951X (Figura 25).

Para o campim-andropogon não houve alteração significativa no teor de $\mathrm{Zn}$ na M.S. com aumento do calcário em ambos os cortes, como mostra a Tabela 40. Porém, a regressão polinomial apresentou diminuição linear, dada pela equação $\mathrm{Y}=$ $52,8191-1,8824 X\left(\mathrm{R}^{2}=0,96\right)$.

Diminuição significativa do teor desse nutriente em capimandropogon, com aumento da dose de calcário utilizada, foi encontrada por PAULINO et al. (1989). 
Tabela 38. Teor de zinco $(\mathrm{Zn})(\mathrm{ppm})$ na M.S. da parte aérea dos cultivares Colonião IZ-1, Vencedor. Centenário e Marandu, no $1^{\circ}$. e $2^{\circ}$. corte (médias de 4 repetições).

\begin{tabular}{|c|c|c|c|c|c|c|}
\hline \multirow{2}{*}{$\begin{array}{l}\text { Níveis } \\
\text { de } \\
\text { calcário }\end{array}$} & \multicolumn{5}{|c|}{$\mathrm{Zn} 1^{\circ}$. corte } & \multirow{2}{*}{$\begin{array}{c}\text { Zn } 2^{\circ} \text {. corte } \\
\text { Média de } \\
16 \text { repet. }\end{array}$} \\
\hline & $\begin{array}{l}\text { Médias de } \\
16 \text { repet. }\end{array}$ & $\begin{array}{c}\text { Colonião } \\
\text { IZ-1 }\end{array}$ & $\begin{array}{l}\text { Vence- } \\
\text { dor }\end{array}$ & $\begin{array}{l}\text { Cente- } \\
\text { nário }\end{array}$ & Marandu & \\
\hline 1 & $33 \mathrm{a}$ & $29 \mathrm{a}$ & $26 a$ & $36 \mathrm{a}$ & $40 \mathrm{a}$ & $57 \mathrm{a}$ \\
\hline 2 & $31 \mathrm{ab}$ & $30 a$ & $25 \mathrm{a}$ & $30 \mathrm{~b}$ & $38 \mathrm{a}$ & $51 \mathrm{ab}$ \\
\hline 3 & $33 \mathrm{a}$ & $29 \mathrm{a}$ & $27 \mathrm{a}$ & $35 \mathrm{a}$ & $40 \mathrm{a}$ & $50 \mathrm{ab}$ \\
\hline 4 & $29 \mathrm{~b}$ & $24 \mathrm{~b}$ & $26 a$ & $29 \mathrm{~b}$ & $36 a$ & $45 \mathrm{~b}$ \\
\hline Teste F & $* *$ & - & - & - & - & ** \\
\hline Reg. linear & $(0,44)^{* *}$ & * & n.s. & $(0,33)^{* *}$ & n.s. & $(0,92)^{* *}$ \\
\hline Reg. quadr. & n.s. & $(0,98)^{*}$ & n.s. & n.s. & n.s. & n.s. \\
\hline C.V. $(\%)$ & 7,99 & - & - & - & - & 15,97 \\
\hline
\end{tabular}

Teste $\mathrm{F}$ para a interação niveis $\mathrm{x}$ cultivares no $1^{\circ}$. corte: *

Niveis de significància: ${ }^{* *} 1 \% ;{ }^{*} 5 \%$; n.s. não significativo.

Médias seguidas pela mesma letra, dentro de cada coluna, não diferem entre si pelo teste de Tukey $5 \%$.

Os valores entre parênteses indicam o coeficiente de determinação $R^{2}$ para a equação.

Tabela 39. Teor de zinco $(\mathrm{Zn})(\mathrm{ppm})$ na M.S. da parte aérea entre os cultivares Colonião IZ-1, Vencedor, Centenário e Marandu, no $1^{\circ}$. e $2^{\circ}$. corte (médias de 4 repetições).

\begin{tabular}{|c|c|c|c|c|c|c|}
\hline \multirow{2}{*}{ Cultivares } & \multicolumn{5}{|c|}{$\mathrm{Zn} 1^{\circ}$. corte } & \multirow{2}{*}{$\begin{array}{c}\text { Zn } 2^{\circ} \text {. corte } \\
\text { Média de } \\
16 \text { repet. }\end{array}$} \\
\hline & $\begin{array}{l}\text { Médias } \\
16 \text { repet. }\end{array}$ & 1 & 2 & 3 & 4 & \\
\hline Col. IZ-1 & $28 \mathrm{c}$ & $29 \mathrm{~b}$ & $30 \mathrm{~b}$ & $29 \mathrm{c}$ & $24 \mathrm{c}$ & $49 \mathrm{~b}$ \\
\hline Vencedor & $26 \mathrm{c}$ & $26 \mathrm{~b}$ & $25 \mathrm{c}$ & $27 \mathrm{c}$ & $26 \mathrm{bc}$ & $57 \mathrm{a}$ \\
\hline Centenário & $33 \mathrm{~b}$ & $36 a$ & $30 \mathrm{~b}$ & $35 \mathrm{~b}$ & $29 \mathrm{~b}$ & $50 \mathrm{ab}$ \\
\hline Marandu & 39 a & $40 \mathrm{a}$ & $38 \mathrm{a}$ & $40 \mathrm{a}$ & $36 a$ & $48 \mathrm{~b}$ \\
\hline Teste $\mathrm{F}$ & ** & - & - & - & - & * \\
\hline C.V. $(\%)$ & 7,99 & - & - & - & - & 15.97 \\
\hline
\end{tabular}

Teste $\mathrm{F}$ para a interação niveis $\mathrm{x}$ cultivares no $1^{\circ}$. corte: *

Níveis de significància: ** $1 \%$; $5 \%$; n.s. não significativo.

Médias seguidas pela mesma letra, dentro de cada coluna, não diferem entre si pelo teste de Tukey $5 \%$. 

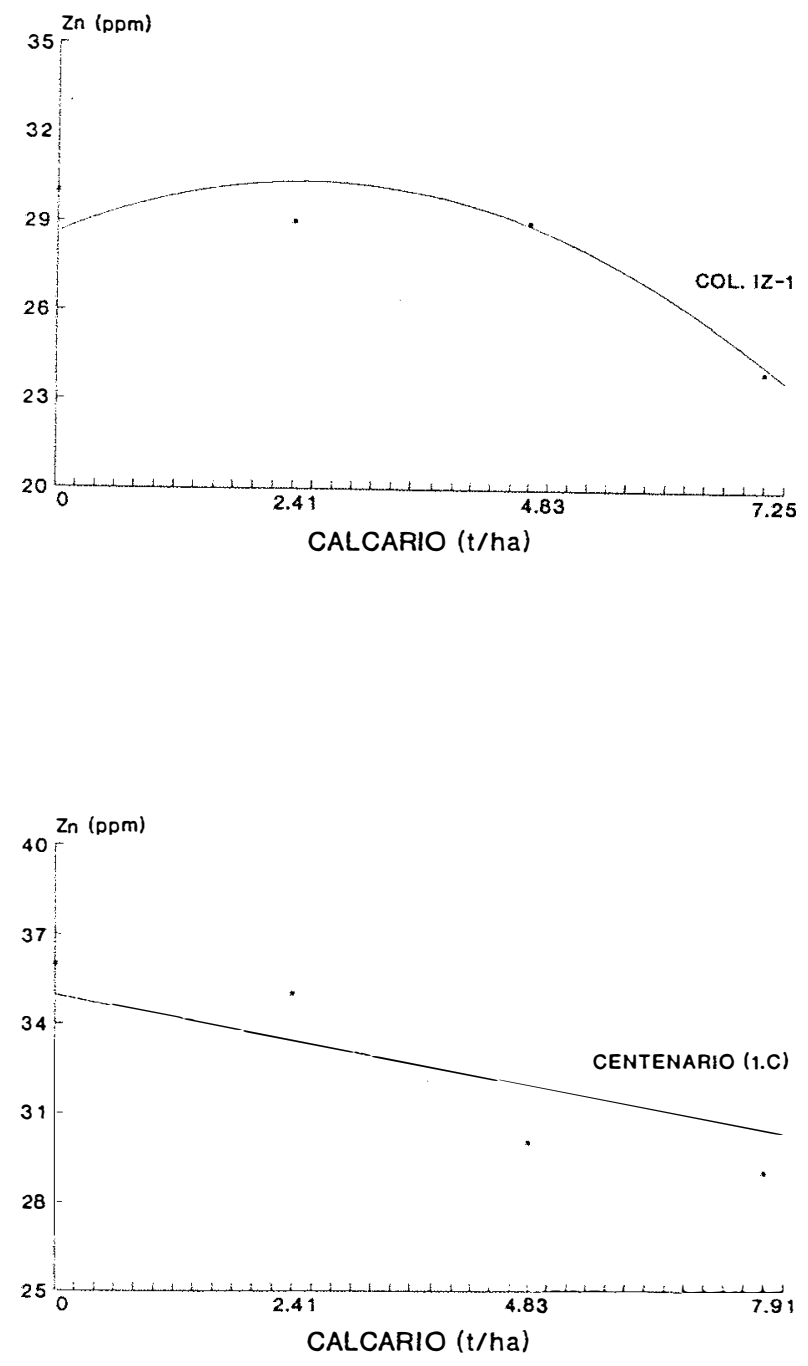

Figura 25. Efeito dos níveis de calcário no teor de Zn na matéria seca da parte aérea dos cultivares Colonião IZ-1 e Centenário no $1^{\circ}$. corte. 

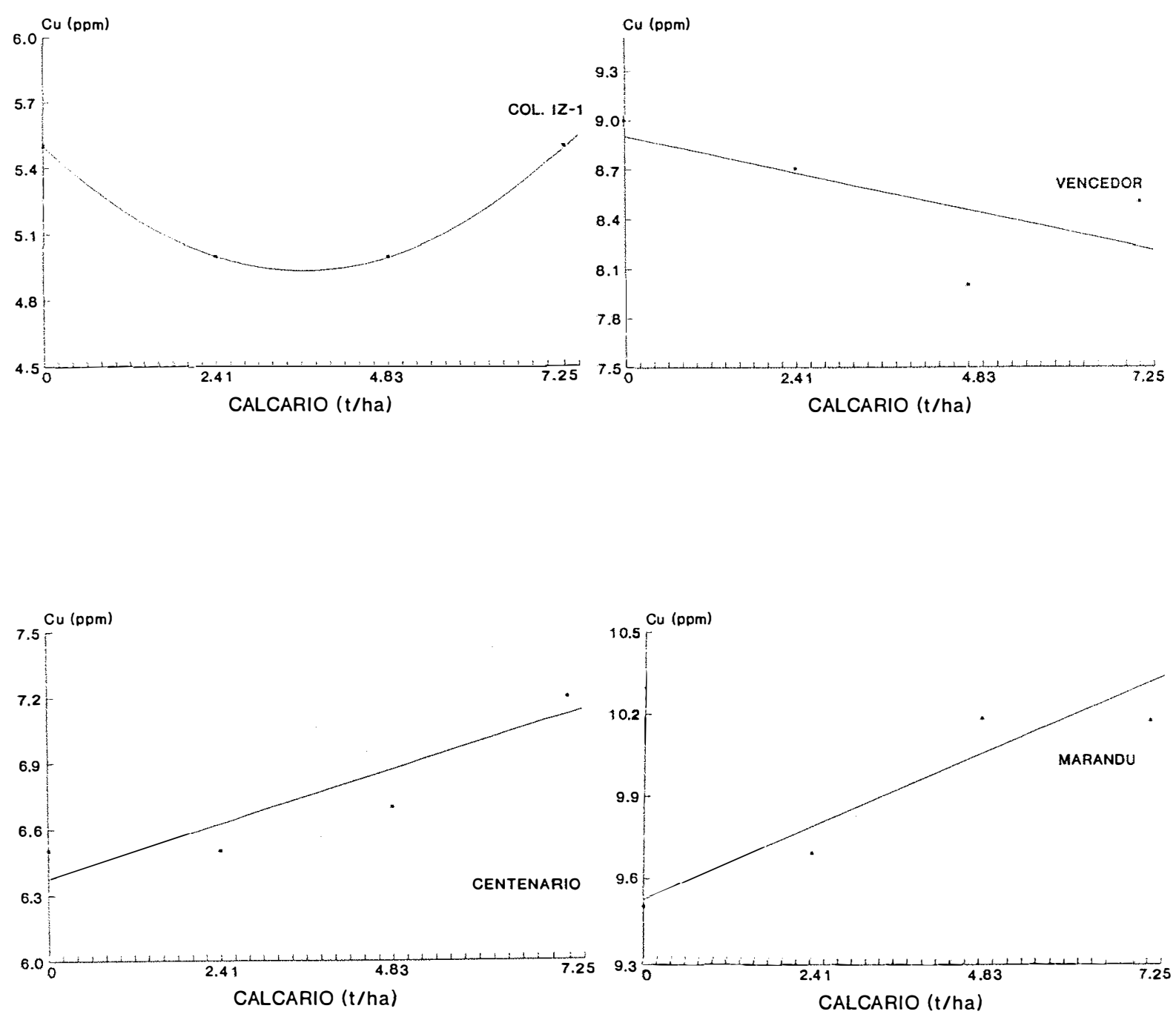

Figura 26. Efeito dos níveis de calcário no teor de $\mathrm{Cu}$ na matéria seca da parte aérea dos cultivares Colonião IZ-1, Vencedor, Centenário e Marandu no $2^{\circ}$. corte. 
Tabela 40. Teores de micronutrientes (ppm) na M.S. da parte aérea do capim andropogon no $1^{\circ}$. e $2^{\circ}$. corte (médias de 4 repetições).

\begin{tabular}{|c|c|c|c|c|c|c|c|c|c|c|}
\hline \multirow{2}{*}{$\begin{array}{l}\text { Niveis } \\
\text { de } \\
\text { calcário }\end{array}$} & \multicolumn{5}{|c|}{$1^{\circ}$. corte } & \multicolumn{5}{|c|}{$2^{\circ}$. corte } \\
\hline & B & $\mathrm{Cu}$ & $\mathrm{Fe}$ & Mn & $\mathrm{Zn}$ & B & $\mathrm{Cu}$ & $\mathrm{Fe}$ & $\mathrm{Mn}$ & $\mathrm{Zn}$ \\
\hline 1 & $21 \mathrm{a}$ & $10 \mathrm{a}$ & $101 \mathrm{a}$ & $186 \mathrm{a}$ & 39 a & $10 \mathrm{a}$ & $7 \mathrm{a}$ & $87 \mathrm{a}$ & $282 \mathrm{a}$ & $53 \mathrm{a}$ \\
\hline 2 & $28 \mathrm{a}$ & $9 \mathrm{a}$ & $100 \mathrm{a}$ & $152 \mathrm{a}$ & $32 \mathrm{a}$ & $11 \mathrm{a}$ & $8 \mathrm{a}$ & 91 a & $225 \mathrm{~b}$ & $47 \mathrm{a}$ \\
\hline 3 & $24 \mathrm{a}$ & $10 \mathrm{a}$ & $101 \mathrm{a}$ & $107 \mathrm{a}$ & $32 \mathrm{a}$ & $11 \mathrm{a}$ & $7 \mathrm{a}$ & $93 \mathrm{a}$ & $152 \mathrm{c}$ & $45 \mathrm{a}$ \\
\hline 4 & $27 \mathrm{a}$ & $11 \mathrm{a}$ & $115 \mathrm{a}$ & $123 \mathrm{a}$ & $32 \mathrm{a}$ & $9 \mathrm{a}$ & $7 a$ & $103 \mathrm{a}$ & $102 \mathrm{~d}$ & $38 \mathrm{a}$ \\
\hline Teste F & n.s. & n.s. & n.s. & n.s. & n.s. & n.s. & n.s. & n.s. & $* *$ & n.s. \\
\hline Regr.linear & n.s. & n.s. & n.s. & $(0,75)^{*}$ & n.s. & n.s. & n.s. & $(0,92)^{*}$ & $(0,99)^{* *}$ & $(0,96)^{*}$ \\
\hline C.V. $(\%)$ & 29.36 & 7,45 & 12,10 & 26.64 & 14,47 & 17,44 & 20,92 & 10,90 & 10.87 & 17,50 \\
\hline
\end{tabular}

Niveis de significância: ${ }^{* *} 1 \% ; * 5 \%$; n.s. não significativo.

Médias seguidas pela mesma letra, dentro de cada coluna, não difierem entre si pelo teste de Tukey $5 \%$.

Os valores entre parênteses indicam o coeficiente de determinação $R^{2}$ para a equação. 


\section{CONCLUSÕES}

Com base nos resultados obtidos no presente trabalho pode-se apontar as seguintes conclusões:

1. Considerando-se os diversos parâmetros analisados, os cultivares Colonião IZ-1, Vencedor, Centenário, Marandu e Andropogon apresentaram comportamentos diferentes entre si quando submetidos a níveis de calcário.

2. Para os cultivares estudados não há necessidade de se fazer calagem quando a saturação por bases do solo estiver em $30 \%$ ou mais, quando cultivados no solo utilizado neste trabalho.

3. Os novos cultivares de gramínea forrageira P. maximum cv. Vencedor e $P$. maximum cv. Centenário não responderam à aplicação de calcário, comportando-se igualmente aos cultivares tradicionalmente plantados em regiões de cerrado. 
4. A aplicação de calcário não interferiu nos teores dos macronutrientes $\mathrm{N}, \mathrm{P}, \mathrm{K}, \mathrm{Ca}, \mathrm{Mg}$ e nos teores de $\mathrm{B}, \mathrm{Cu}, \mathrm{Fe}$ e $\mathrm{Zn}$ na matéria seca da parte aérea do capim-andropogon no $1^{\circ}$. e $2^{\circ}$. cortes.

5. Os teores de potássio na matéria seca apresentaram-se mais elevados nos novos cultivares Vencedor e Centenário que nos cultivares Colonião IZ-1 e Marandu, independente do nível de calcário empregado no $1^{\circ}$. corte.

6. O cultivar Vencedor, no $1^{\circ}$, corte, apresentou maior teor de Ca na matéria seca independente do nível de calcário utilizado. 


\section{REFERÊNCIAS BIBLIOGRÁFICAS}

ABRUÑA, F. \& FIGARELLA, J. Some effects of calcium and phosphorus fertilization on the yield and composition of a tropical kudzu-grass pasture. Joumal of Agricultura of the University of Puerto Rico, Rio Piedras, 41(4): 231-5, 1957.

ABRUÑA, F.; VICENTE-CHANDLER, J.; PEARSON, R.W. Effect of liming on yields and composition of heavily fertilized grasses and on soil properties under humid tropical conditions. Proceedings Soil Science Society of American, Madison, 28(5): 657-61, 1964.

ALCÂNTARA, P.B. \& BUFARAH, G. Plantas forrageiras; gramíneas e leguminosas. São Paulo, Nobel, 1979. 150p.

ALCARDE, J.C. Características dos corretivos da acidez do solo. In: SIMPÓSIO SOBRE APLICAÇÃO DE CALCÁRIO NA AGRICULTURA, 1., Ipanema, 1986. Trabalhos apresentados. Campinas, Fundação Cargill, 1986. p.1-19.

AZEVEDO, L.G. \& CASER, R.L. Regionalização do cerrado. In: SIMPÓSIO SOBRE O CERRADO, 5., Brasília, 1979. Cerrado; uso e manejo. Brasília, Editerra, 1982. p.213-21. 
BARCELLOS, A.O. \& SANZONOWICZ, C. Resposta à calcário e fósforo de três Panicum maximum selecionados para baixa fertilidade do solo. In: REUNIÃO ANUAL DA SOCIEDADE BRASILEIRA DE ZOOTECNIA, 24., Brasília, 1987. Anais. Brasília, SBZ, 1987. p.155.

BATAGLIA, O.C.; FURLANI, A.M.C.; TEIXEIRA, J.P.F.; FURLANI, P.R.; GALLO, J.R. Métodos de análise química de plantas. Campinas, Instituto Agronômico, 1983. 48p. (IAC. Boletim Técnico, 78).

BERROTERÁN, J.L. Respuesta de Andropogon gayanus y Digitaria swazilandensis a la fertilización en los Llanos Centrales de Venezuela. Pasturas Tropicales, Cali, 11(3): 2-7, 1989.

BRENES, E. \& PEARSON, R.W. Roots responses of three gramineas to soil acidity in an oxisol and on ultisol. Soil Science, Baltimore, 116(4): 295-302, 1973.

CARRIEL, J.M.; WERNER, J.C.; ABRAMIDES, P.L.G.; MONTEIRO, A.M.; MEIRELLES, N.M.F. Limitações nutricionais de um solo podzólico vermelhoamarelo para o cultivo de três gramíneas forrageiras. Boletim da Indústria Animal, Nova Odessa, 46(1): 61-73, 1989.

CASAGRANDE, J.C. \& SOUZA, O.C. de. Efeito de níveis de enxofre sobre quatro gramíneas forrageiras tropicais em solos sob vegetação de cerrado do estado do Mato Grosso do Sul, Brasil. Pesquisa Agıopecuánia Bıasileira, Brasília, 17(1): 21-5, 1982.

CENTRO INTERNACIONAL DE AGRICULTURA TROPICAL. Nutrición mineral de plantas forrajeras. In: Informe anual 1977. Cali, 1978. p.A.61 - A.65.

CENTRO INTERNACIONAL DE AGRICULTURA TROPICAL. Informe anual 1979; pastos tropicales, Cali, 1980. 186p. 
CENTRO INTERNACIONAL DE AGRICULTURA TROPICAL. Fertilidad del suelo y nutricion de plantas. In: Informe anual 1981; pastos tropicales, Cali, 1982. p.171-94.

CENTRO INTERNACIONAL DE AGRICULTURA TROPICAL. Desarrollo de pastos en los cerrados. In: Informe anual 1988; pastos tropicales, Cali, 1989. p.13.1-13.10 (Documento de Trabajo, 59).

CENTRO INTERNACIONAL DE AGRICULTURA TROPICAL. Desarrollo de pastos en los cerrados. In: Informe anual 1989; pastos tropicales. Cali, 1990. p.13.1-13.10 (Documentos de Trabajo, 69).

COLEMAN, N.T. \& THOMAS, S.W. The basic chemistry of soil acidity. In: PEARSON, R.W. \& ADAMS, F., ed. Soil acidity and lime. Madison, American Society of Agronomy, 1967. p.1-41 (Agronomy, 12).

COLOZZA, M.T.; SAVASTANO, S.A.L.; WERNER, J.C.; MONTEIRO, F.A. Efeito da aplicação de gesso e calcário dolomítico em dois solos ácidos cultivados com sojaperene (1). Boletim da Indústria Animal, Nova Odessa, 40(1): 75-96, 1983.

COUTO, W.; LEITE, G.G.; KORNELIUS, E. The residual effect of $P$ and lime on the performance of four tropical grasses in a high P-fixing oxisol. Agronomy Joumal, Madison, 77(4): 539-42, 1985.

COUTO, W.; LEITE, G.G.; SANZONOWICZ, C. Response of andropogon grass to P fertilizers and lime in a Dark-Red Latosol of the cerrados. Pesquisa Agropecuána Brasileira, Brasília, 26(3): 297-304, 1991.

EMPRESA BRASILEIRA DE PESQUISA AGROPECUÁRIA. Centro Nacional de Pesquisa de Gado de Corte. Brachiaria brizantha cv. Marandu. Campo Grande, 1985a. $31 \mathrm{p}$. 
EMPRESA BRASILEIRA DE PESQUISA AGROPECUÁRIA. Centro de Pesquisa Agropecuária dos Cerrados. Relatório técnico anual 1981/82. Planaltina, 1985b. $177 \mathrm{p}$.

EMPRESA BRASILEIRA DE PESQUISA AGROPECUÁRIA. Centro de Pesquisa Agropecuária dos Cerrados, Capim vencedor; nova opção para a formação de pastagens nos cerrados. Planaltina, 1990. n.p.

EMPRESA BRASILEIRA DE PESQUISA AGROPECUÁRIA. Centro de Pesquisa Agropecuária dos Cerrados. Relatónio técnico anual 1977/78. Planaltina, 1979. 192p.

EMRICH, E.S. Competição entre cinco gramíneas forrageiras para a formação de pastagens em solo de cerrado. In: REUNIÃO BRASILEIRA DE CERRADOS, 2., Sete Lagoas, 1967. Anais. Sete Lagoas, São Vicente, 1972. p.209-21.

EPSTEIN, E. Nutrição mineral das plantas; princípios e perspectivas. São Paulo, EDUSP, 1975. 344p.

FALADE, J.A. The effect of phosphorus on growth and mineral composition of five tropical grass. East African Agricultural and Forestry Joumal, Nairobi, 40(4): 342-59, 1975.

FERNANDES, M.S.; ROSSIELLO, R.O.; ARRUDA, M.L.R. Relações entre capacidade de troca de cátions das raízes e toxidez de alumínio em duas gramíneas. Pesquisa Agıpecuánia Brasileira, Brasília, 19(5): 631-7, 1984.

FERRARI NETO, J. Limitações nutricionais para o colonião (Panicum maximum Jacq.) e braquiária (Brachiaria decumbens Stapt) em latossolo da região noroeste do Estado do Paraná. Lavras, 1991. 126p. (Mestrado - Escola Superior de Agricultura de Lavras). 
FOY, C.D. Effect of aluminum on plant growth. In: CARSON, E.W., ed. The plant root and its environment. Charlottesville, University Press of Virginia, 1974. p.601-43.

GALLO, J.R.; HIROCE, R.; BATAGLIA, O.C.; FURLANI, P.R.; FURLANI, A.M.C.; MATTOS, H.B.; SARTINI, H.J.; FONSECA, M.P. Composição química inorgânica de forrageiras do Estado de São Paulo. Boletim da Indústria Animal, Nova Odessa, 31(1): 115-37, 1974.

GALRÃO, E.Z. \& LOPES, A.S. Deficiências nutricionais em solos de cerrado. In: SIMPÓSIO SOBRE O CERRADO, 5., Brasília, 1979. Cerrado; uso e manejo. Brasília, Editerra, 1982. p.597-616.

GHISI, O.M.A.A. \& PEDREIRA, J.V.S. Características agronômicas das principais Brachiaria spp. In: ENCONTRO SOBRE CAPINS DO GÊNERO BRACHIARIA, 1., Nova Odessa, 1986. Anais. Nova Odessa, Instituto de Zootecnia, 1987.

GOEDERT, W.J.; RITCHEY, K.D.; SANZONOWICZ, C. Desenvolvimento radicular do capim andropogon e sua relação com o teor de cálcio no perfil do solo. Revista Brasileira de Ciência do Solo, Campinas, 9(1): 89-91, 1985.

GOMIDE, J.A.; ZAGO, C.P.; RIBEIRO, A.C.; BRAGA, J.M.; MARTINS, O. Calagem, fontes e níveis de fósforo no estabelecimento e produção de capim colonião (Panicum maximum Jacq.) no cerrado. Revista da Sociedade Brasileira de Zootecnia, Viçosa, 15(3): $241-6,1986$.

HADDAD, C.M. Efeito do enxofre, aplicado na forma de gesso, sobre a produção e qualidade do capim colonião (Panicum maximum Jacq.). Piracicaba, 1983. 115 p. (Doutorado - Escola Superior de Agricultura "Luiz de Queiroz"/USP).

HELYAR, K.R. Effect of aluminium and manganese toxicity on legume growth. In: ANDREW, C.S. \& KAMPRATH, E.J., ed. Mineral nutricion of legumes; tropical and subtropical soils. Melbourne, CSIRO, 1978. p.207-31. 
HUTTON, E.M. \& SOUSA, F.B. Melhoramento de Panicum maximum para latossolos ácidos e de baixa fertilidade. In: REUNIÃO ANUAL DA SOCIEDADE BRASILEIRA DE ZOOTECNIA, 24., Brasília, 1987. Anais. Brasília, SBZ, 1987. p.231.

JANK, L.; SAVIDAN, Y.H.; COSTA, J.C.G. Seleção de cultivares de Panicum maximum quanto à exigência de fertilidade e tolerância à seca. In: REUNIÃO ANUAL DA SOCIEDADE BRASILEIRA DE ZOOTECNIA, 24,, Brasília, 1987. Anais. Brasília, SBZ, 1987. p.223.

JONES, M.B. \& FREITAS, L.M.M. Resposta de quatro leguminosas tropicais a fósforo, potássio e calcário num latossolo vermelho amarelo de campo cerrado. Pesquisa Agropecuária Brasileira, Rio de Janeiro, 5(3): 91-9, 1970.

KORNELIUS, E.; SAUERESSIG, M.G.; GOEDERT, W.J. Estabelecimiento y manejo de praderas en los cerrados del Brasil. In: TERGAS, L.E. \& SÁNCHEZ, P.A., ed. Producción de pastos en suelos acidos de los tropicos. Cali, CIAT, 1979. p.159-79.

LIMA, S.A.A. de \& MATTOS, H.B. de. Nutrição mineral em cinco estilosantes cultivados em um solo de cerrado paulista. II. Teores de cálcio, fósforo, magnésio, potássio, cobre, ferro, zinco e manganês. Boletim da Indústria Animal, Nova Odessa, 39(2): 93-105, 1982.

LOPES, A.S. Solos sob cerrado; características, propriedades e manejo. 2.ed. Piracicaba, Associação Brasileira para a Pesquisa da Potassa e Fosfato, 1984. 162p.

LOURENÇO, A.J. \& SARTINI, H.J. Efeito da fertilização fosfatada e da lotação nas concentrações de fósforo e cálcio no solo, na forragem disponível e no soro sangüíneo de bovinos (1). Boletim da Indústria Animal, Nova Odessa, 39(1): 1-10, 1982. 
LOTERO, J.C.; MONSALVE, S.A.; RAMÍREZ, A.; VILLAMIZAR, F. Respuesta de gramineas y leguminosas forrajeras al encalamiento. Suelos Equatoriales, Bogotá, 3: 210-39, 1971.

MALAVOLTA, E. Manual de química agrícola; nutrição de plantas e fertilidade do solo. São Paulo, Agronômica Ceres, 1976. 528p.

MALAVOLTA, E.; VITTI, G.C.; FORNASIERI F., D.; GUIMARÃES, P.T.G.; GUILHERME, M.R.; EIMORI, I.; VASCONCELLOS, L.A.B.C.; MORAES, C.L.; KAMISKY, J.; MUTTON, M.A.; CARVALHO, J.G.; RUY, V.M. Efeito de doses e fontes de enxofre em culturas de interesse econômico. I. Capim colonião (Panicum maximum Jacq.). Boletim Técnico SN, São Paulo, (3): 9-22, 1984.

MARTINEZ, H.E.P.; ALOISI, A.M.D.; BOLIANI, A.C. Macronutrientes em gramíneas. In: HAAG, H.P. Nutrição mineral de forageiras no Brasil. Campinas, Fundação Cargill, 1984. p.3-73.

MATTOS, H.B. de \& COLOZZA, M.T. Macronutrientes em pastagens. In: SIMPÓSIO SOBRE CALAGEM E ADUBAÇÃO DE PASTAGENS, 1., Nova Odessa, 1985. Anais. Piracicaba, POTAFOS, 1986. p.233-56.

McCOSKER, T.H. \& TEITZEL, J.K. A review of guineagrass (Panicum maximum) for the wet tropics of Australia. Tropical Grasslands, Brisbane, 9(3): 177-90, 1975.

MEIRELLES, N.M.F.; WERNER, J.C.; ABRAMIDES, P.L.G.; CARRIEL, K.M.; PAULINO, V.T.; COLOZZA, M.T. Nível crítico de fósforo em capim colonião cultivado em dois tipos de solo: Latossolo Vermelho-Escuro e Podzólico VermelhoAmarelo. Boletim da Indústria Animal, Nova Odessa, 45(1): 215-32, jan/jun. 1988.

MENDES, J.F. Características químicas e físicas de alguns solos sob cerrado. In: REUNIÃO BRASILEIRA DE CERRADOS, 2., Sete Lagoas, 1967. Anais. Sete Lagoas, Ed. São Vicente, 1972. p.51-62. 
MIRANDA, L.N.; MIELNICZUK, J.; LOBATO, E. Calagem e adubação corretiva. In: SIMPÓSIO SOBRE O CERRADO, 5., Brasília, 1979. Cerrado; uso e manejo. Brasília, Editerra, 1982. p.523-78.

MITIDIERI, J. Manual de gramíneas e leguminosas para pastos topicais. 2.ed., São Paulo, Nobel, 1988. 198p.

MONTEIRO, F.A. \& CARRIEL, J.M. Aplicação de niveis de enxofre na forma de gesso para cultivo do capim colonião em dois solos arenosos do Estado de São Paulo. Boletim da Indústria Animal, Nova Odessa, 44(2): 335-47, 1987.

MONTEIRO, F.A; MALAVOLTA, F.; WERNER, J.C. Efeito da aplicação de micronutrientes e de níveis de calagem em leguminosas forrageiras (1): soja perene tinaroo e siratro cultivado em vasos. Boletim da Indústria Animal, Nova Odessa, 40(1): 97-126, 1983.

MOURTHÉ, H. Considerações sobre recuperação de cerrados. In: REUNIÃO BRASILEIRA DE CERRADOS, 2., Sete Lagoas, 1967. Anais. Sete Lagoas, Ed. São Vicente, 1972. p.239-43.

OLIVEIRA, P.R.P. de ALCÂNTARA, P.B. Capim colonião (Panicum maximum Jacq.): caracterização e reprodução. Zootecnia, Nova Odessa, 16(3): 123-32, 1978.

OLMOS, J.I.L. \& CAMARGO, M.N. Ocorrência de alumínio tóxico nos solos do Brasil, sua caracterização e distribuição. Ciência e Cultura, São Paulo, 28(2): 171-80, 1976.

OLSEN, S.R. Micronutrient interactions. In: MORTVEDT, J.J.; GIORDANO, P.M.; LINDSAY, W.L., ed. Micronutrients in agriculture. Madison, Soil Science Society of America, 1972. p.243-64. 
PAULINO, V.T. Efeito da fertilização fosfatada, da calagem e micronutrientes no desenvolvimento de plantas forrageiras. Piracicaba, 1990. 290p. (Doutorado Escola Superior de Agricultura "Luiz de Queiroz"/USP).

PAULINO, V.T.; ANTON, D.P.; COLOZZA, M.T. Problemas nutricionais do gênero Brachiaria e algumas relações com o comportamento animal. Zootecnia, Nova Odessa, 25(3): 197-214, 1987.

PAUlino, V.T.; MALAVOLTA, E.; PIGATO, A.M. Efeito de níveis de fosfogesso e calagem sobre o cultivo do capim Andropogon (Andropogon gayanus Kunth.). Revista de Agricultura, Piracicaba, 64(1): 55-90, 1989.

PEARSON, R.W. \& HOVELAND, G.S. Lime needs of forage crop. In: MAYS, D.A., ed. Forage fertilization. Madison, American Society of Agronomy, 1974. p.301-22.

PEREIRA, J.P. Adubação de capins do gênero Brachiaria. In: ENCONTRO SOBRE CAPINS DO GÊNERO BRACHIARIA, 1., Nova Odessa, 1986. Anais. Nova Odessa, Instituto de Zootecnia, 1987.

PORZECANSKY, J. Melhoramento de plantas forrageiras alternativas para adaptação a solos tropicais. In: SEMINÁRIO SOBRE NUTRIÇÃO DE PLANTAS FORRAGEIRAS EM SOLOS TROPICAIS ÁCIDOS, Campo Grande, 1979. Anais. Campo grande, EMBRAPA-CNPGC, 1979. p.57-66.

PREMAZZI, L.M. Saturação por bases como critério para recomendação de calagem em cinco forrageiras tropicais. Piracicaba, 1991. 215p. (Mestrado - Escola Superior de Agricultura "Luiz de Queiroz"/USP).

QUAGGIO, J.A. Critérios para calagem em solos do Estado de São Paulo. Piracicaba, 1983. 76p. (Mestrado - Escola Superior de Agricultura "Luiz de Queiroz"/USP). 
RAIJ, B. van. Avaliação da fertilidade do solo. Piracicaba, Instituto da Potassa \& Fosfato, 1981. 142p.

RAIJ, B. van. Gesso agrícola na melhoria do ambiente radicular no subsolo. São Paulo, Associação Nacional para Difusão de Adubos e Corretivos Agrícolas, 1988. 88p.

RAIJ, B. van; QUAGGIO, J.A.; CANTARELLA, H.; FERREIRA, M.E.; LOPES, A.S.; BATAGLIA, O.C. Análise química de solo para fins de fertilidade. Campinas, F undação Cargill, 1987. 170p.

RAIJ, B. van; SILVA, N.M.; BATAGLIA, O.C.; QUAGGIO, J.A.; HIROCE, R.; CANTARELLA, H.; BELLINAZZI JÚNIOR, R.; DECHEN, A.R.; TRANI, P.E. Recomendações de adubação e calagem para o Estado de São Paulo. Campinas, Instituto Agronômico, 1985. 107p. (IAC. Boletim Técnico, 100).

SANZONOWICZ, C.; LOBATO, E.; GOEDERT, W.J. Efeito residual de calagem e de fonte de fósforo numa pastagem estabelecida em solo de cerrado. Pesquisa Agropecuária Brasileira, Brasília, 22(3): 233-43, 1987.

SILVA, A.R. de. Melhoramento genético para resistência à toxidez de alumínio e manganês no Brasil. Antecedentes, necessidade e possibilidades. Tópicos para discussão e pesquisas. Ciência e Cultura, São Paulo, 28(2): 147-9, 1976.

SIQUEIRA, C. Calagem para plantas forrageiras. In: SIMPÓSIO SOBRE CALAGEM E ADUBAÇÃO DE PASTAGENS, 1., Nova Odessa, 1985. Anais. Piracicaba, POTAFÓS, 1986. p.77-91.

SIQUEIRA, C.; CARVALHO, M.M.; SARAIVA, O.F.; OLIVEIRA, F.T.T. Resposta de três gramíneas forrageiras tropicais à aplicação de calcário e fósforo em um solo ácido. In: CONGRESSO BRASILEIRO DE ZOOTECNIA, 1., REUNIÃO ANUAL DA SOCIEDADE BRASILEIRA DE ZOOTECNIA, 17., Fortaleza, 1980. Anais. Fortaleza, SBZ, 1980. p.473. 
SMITH, F.W. \& DOLBY, G.R. Derivation of diagnostic indices for assessing the sulphur status of Panicum maximum var. Trichoglume. Communications in Soil Science and Plant Analysis, Athens, 8(3): 221-40, 1977.

SOUZA, D.M.G. de; CARVALHO, L.J.C.B.; MIRANDA, L.N. de. Correção da acidez do solo. In: GOEDERT, N.J. Solos dos cerrados; tecnologia e estratégia de manejo. São Paulo, Nobel, 1985. p.99-127.

SOUZA, S.O. de; PINTO, J.C.; ROCHA, G.P.; MUNIZ, J.A. Influência da idade na composição química de quatro gramíneas forrageiras tropicais. Ciência e Prática, Lavras, 13(1): 56-64, 1989.

SPAIN, J.M. Estabelecimiento y manejo de pastos en los llanos orientales de Colombia. In: TERGAS, L.E. \& SANCHEZ, P.A., ed. Producción de pastos en suelos acidos de los topicos. Cali, CIAT, 1979. p.181-9.

SPAIN, J.M. \& ANDREW, C.S. Mineral characterization of species. Six tropical grasses $\mathrm{x}$ four aluminium treatments in water culture. In: COMMONWEALTH SCIENTIFIC AND INDUSTRIAL RESEARCH ORGANIZATION. Division of Tropical Crops and Pastures. Annual report 1975-1976. St. Lucia, 1976. p.50.

THOMS, D. \& LAPOINTE, S. Testing new accessions of guinea-grass (Panicum maximum ) for acid soils and resistance to spittlebug (Aeneolamia reducta). Tropical Grasslands, St. Lucia, 23(4): 232-9, 1989.

THOMAS, D.; ANDRADE, R.P. de; COUTO, W.; ROCHA, C.M.C. da; MOORE, P. Andropogon gayanus var. bisquamulatus cv. Planaltina: principais características forrageiras. Pesquisa Agıopecuánia Brasileira, Brasília, 16(3): 347-55, 1981.

USBERTI FILHO, J.A. Capim colonião IAC-Centenário. Casa da Agricultura, Campinas, 10(3): 11-3, 1988. 
USBERTI FILHO, J.A.; FURLAN, P.R.; GALLO, P.B.; PEREIRA, C.A.; DENNUCCI, S. Avaliação de híbridos e cultivares de capim colonião (Panicum maximum Jacq.) quanto à tolerância ao alumínio. In: REUNIÃO ANUAL DA SOCIEDADE BRASILEIRA DE ZOOTECNIA, 24., Brasília, 1987. Anais. Brasília, SBZ, 1987. p.167.

VITTI, G.C. \& NOVAES, N.J. Adubação com enxofre. In: SIMPÓSIO SOBRE CALAGEM E ADUBAÇÃO DE PASTAGENS, 1., Nova Odessa, 1985. Anais. Piracicaba, POTAFOS, 1986. p.191-231.

WERNER, J.C. Adubação de pastagens. Nova Odessa, Instituto de Zootecnia, 1986. 46p. (IZ. Boletim Técnico, 18).

WERNER, J.C.; MONTEIRO, F.A.; CARRIEL, J.M. Efeitos da calagem em capim colonião. Boletim da Indústria Animal, Nova Odessa, 36(2): 247-53, 1979.

WERNER, J.C.; QUAGLIATO, J.L.; MARTINELLI, D. Ensaio de fertilização do colonião com solo da "noroeste". Boletim da Indústria Animal, Nova Odessa, 24: 159-67, 1967. 
A P Ê N D I C E 


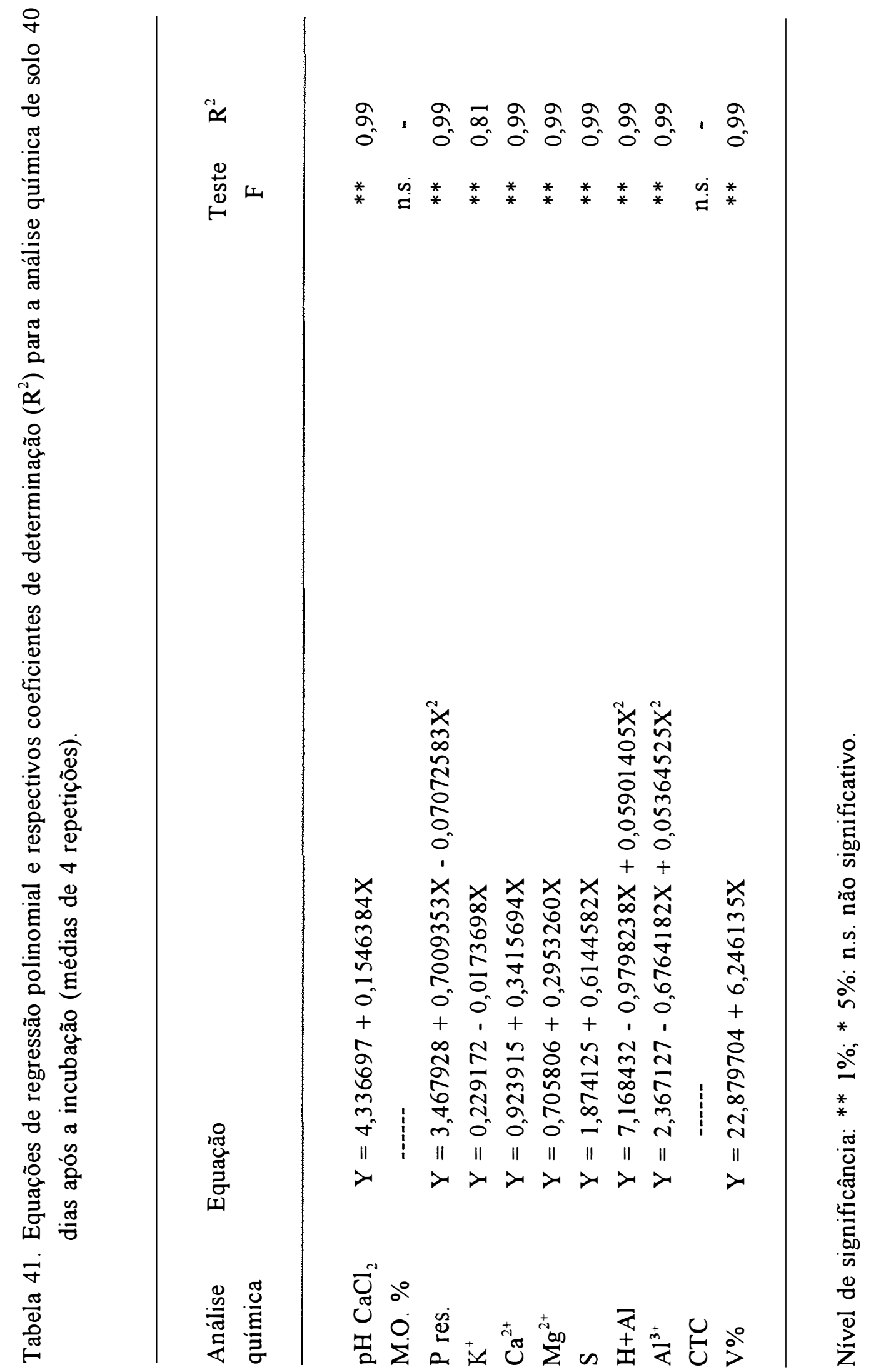




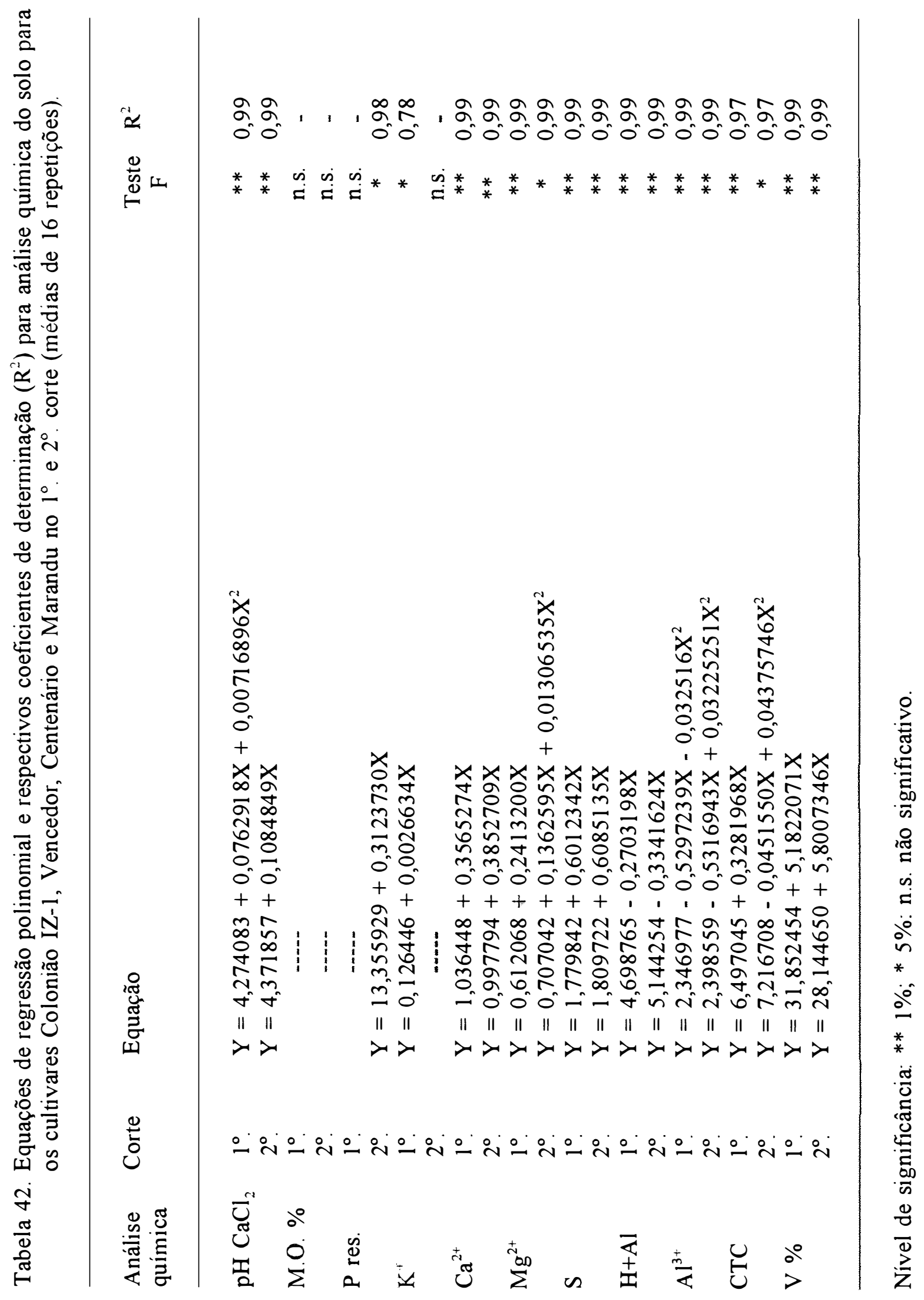




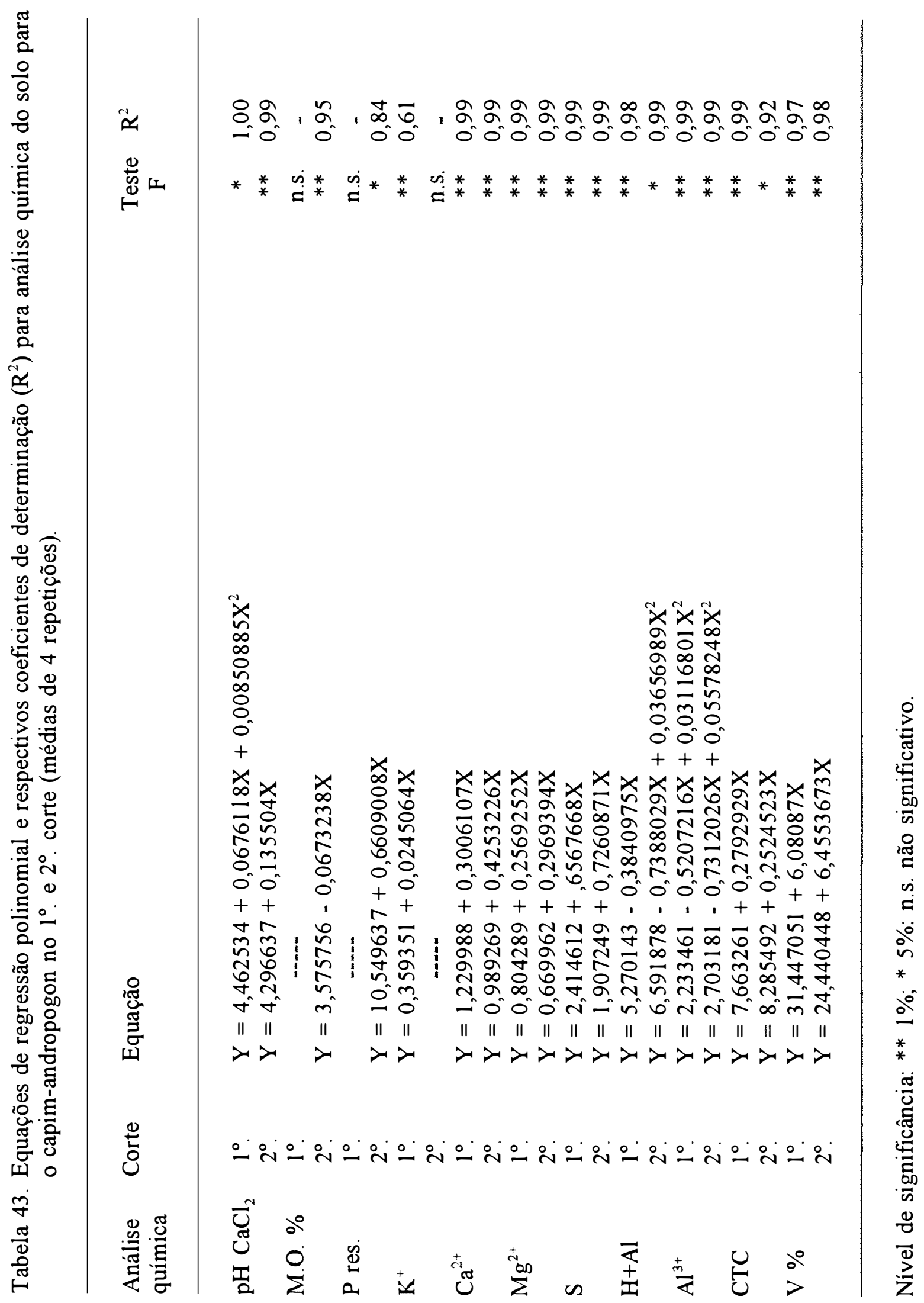




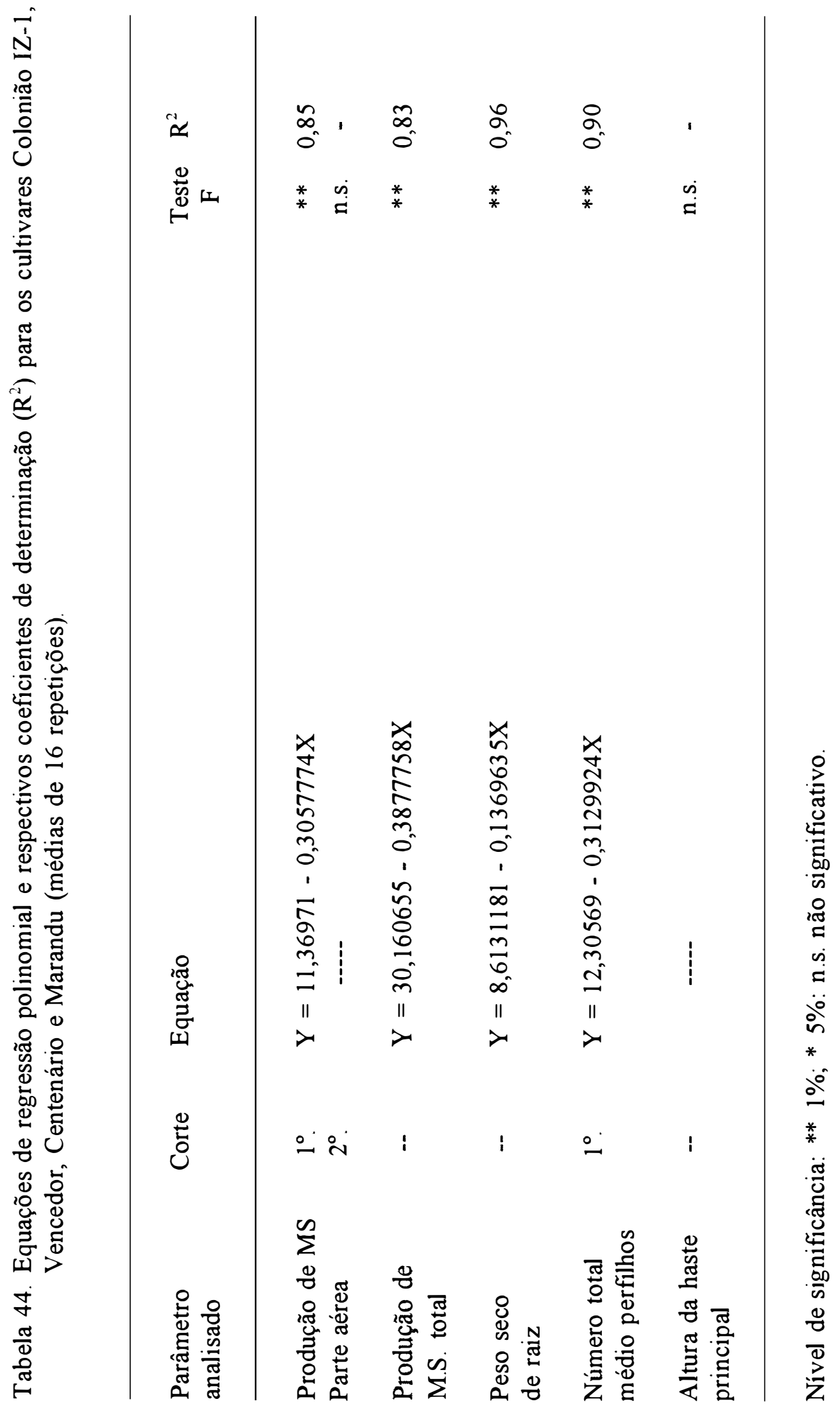




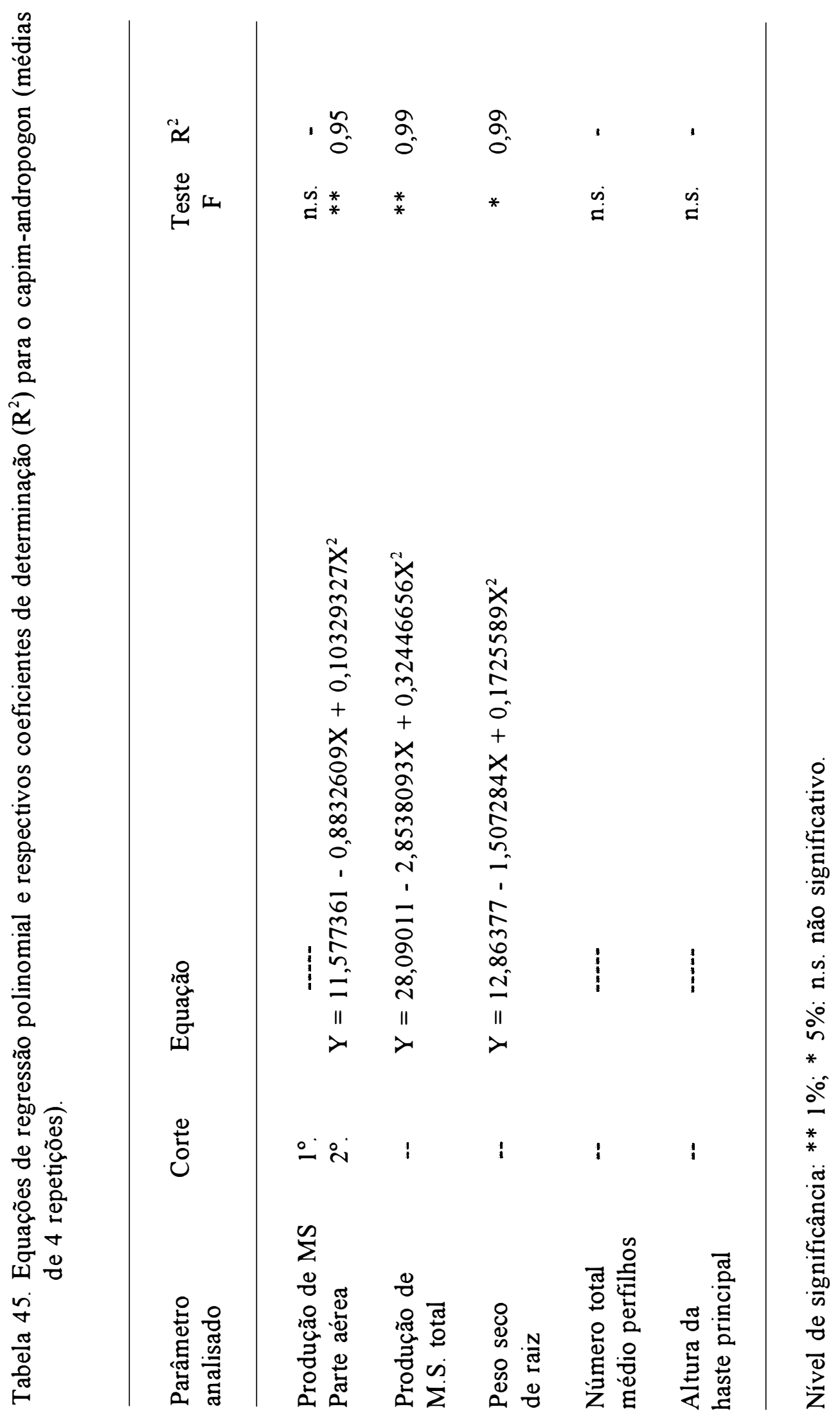




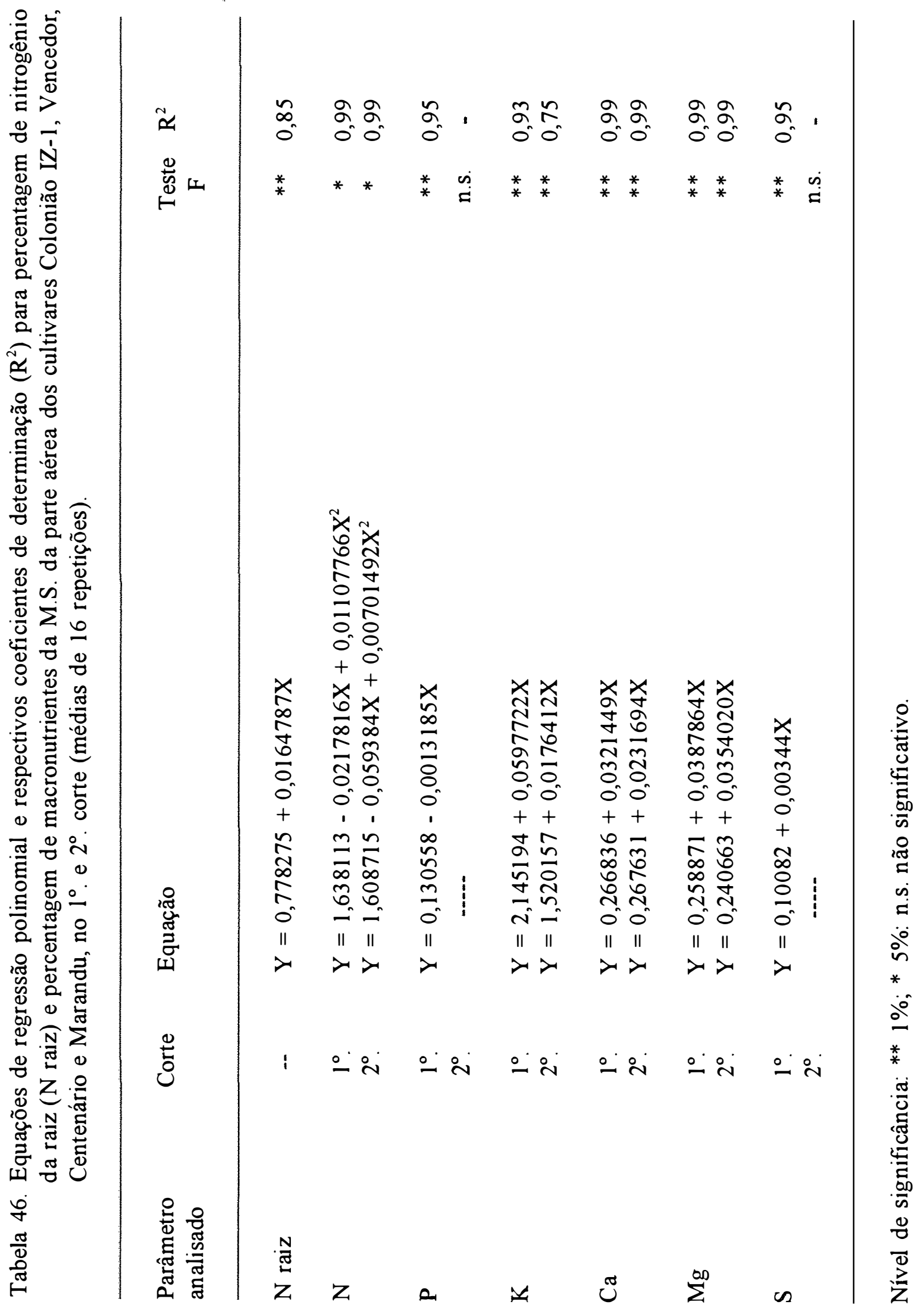




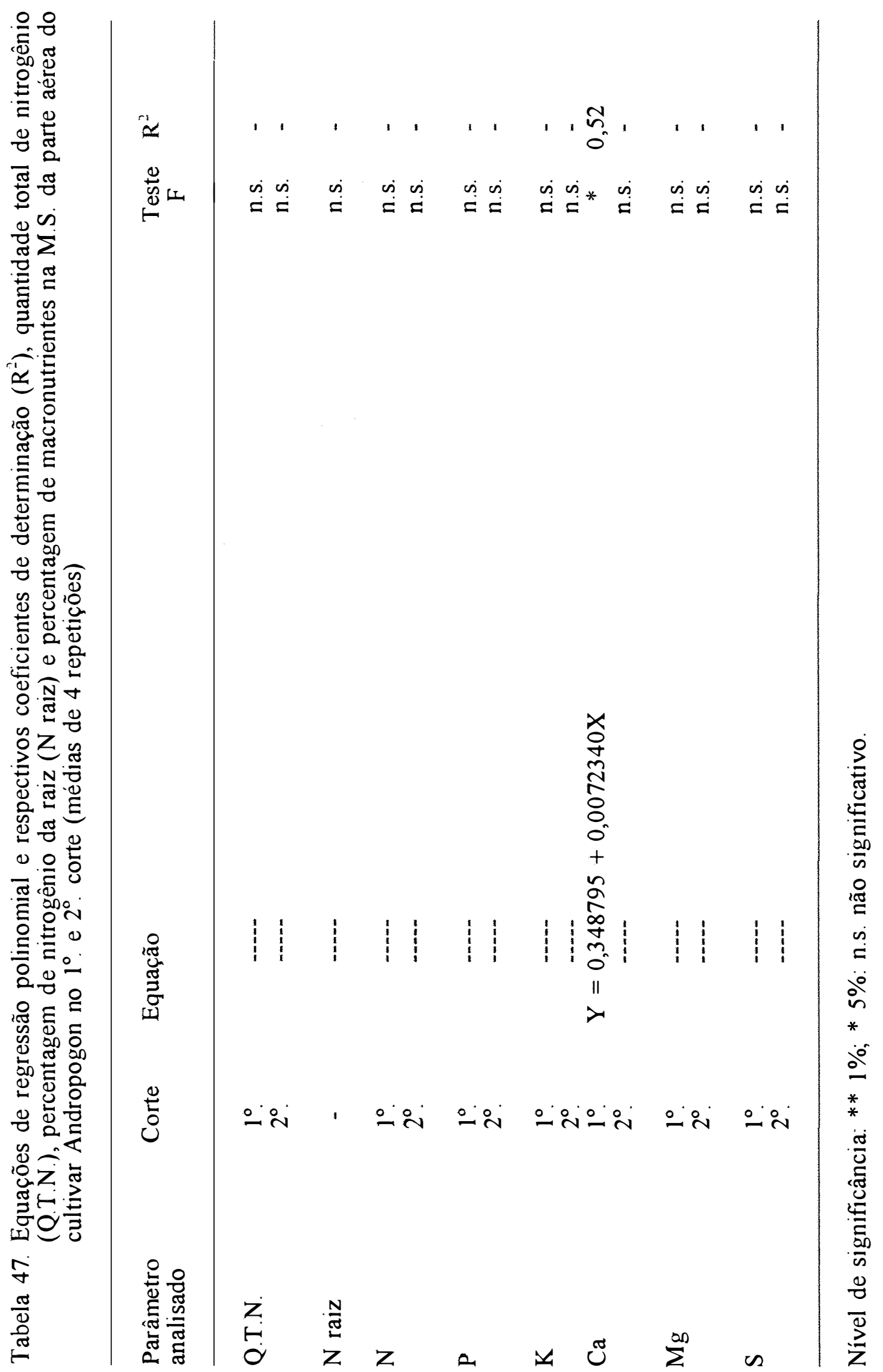




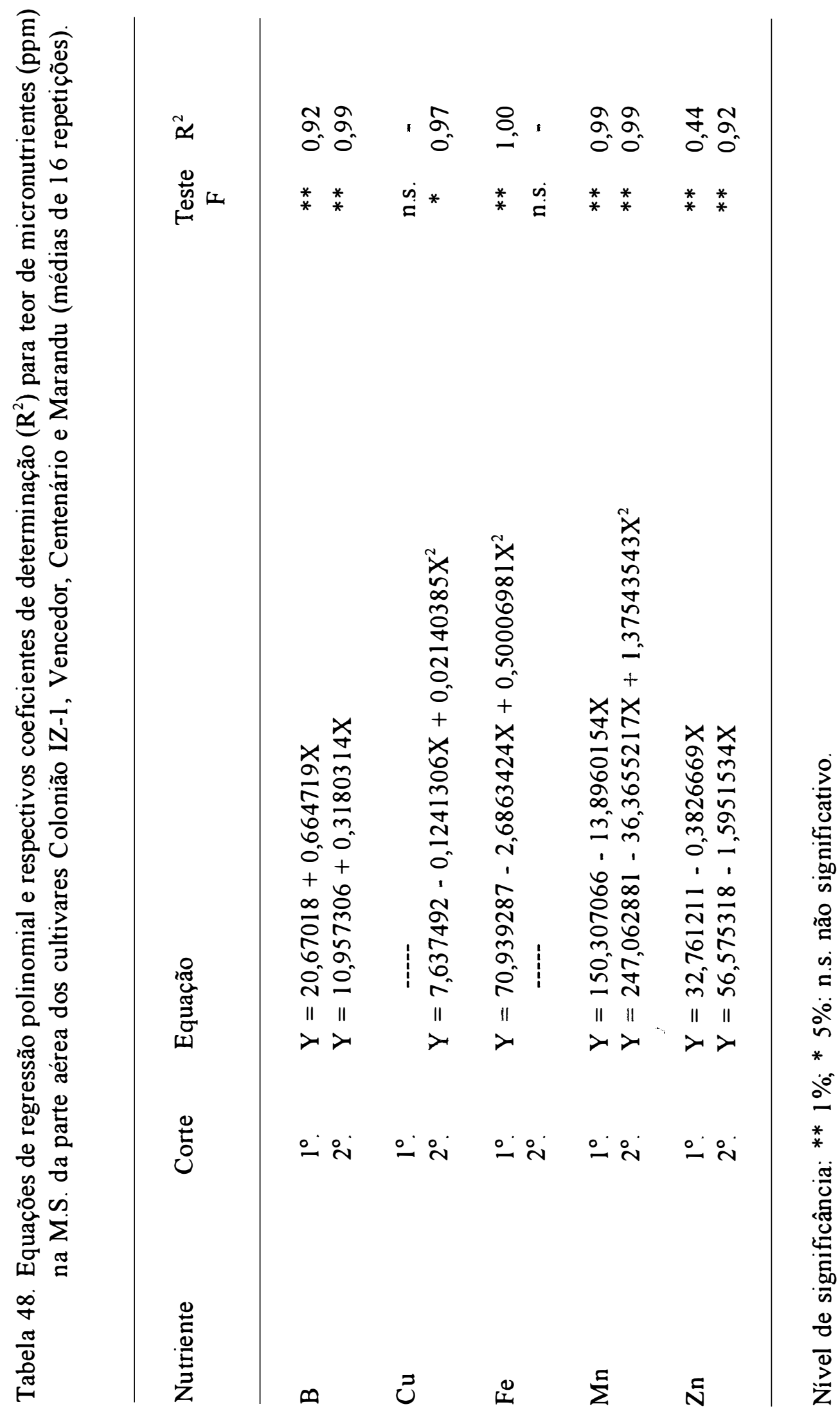




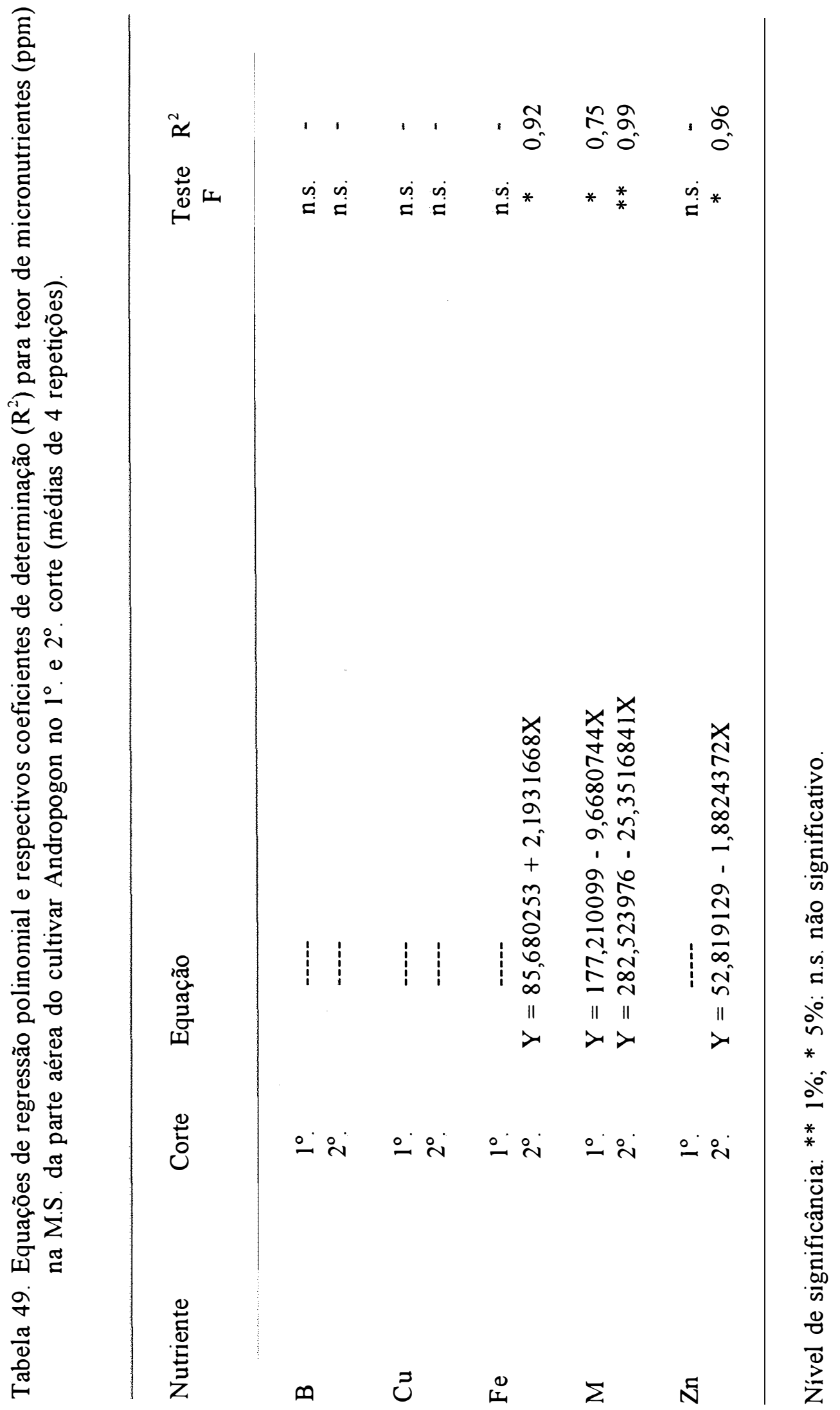




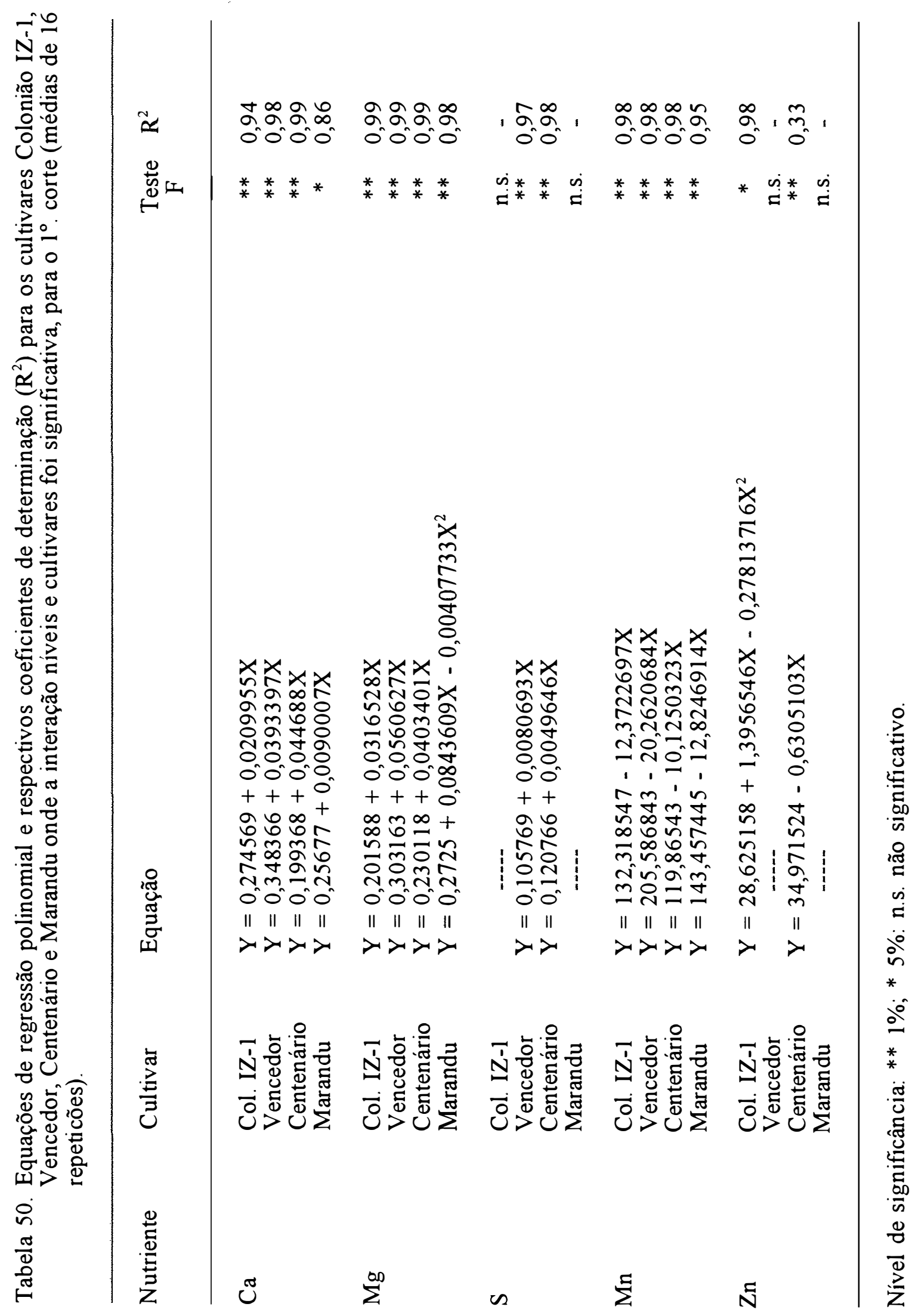




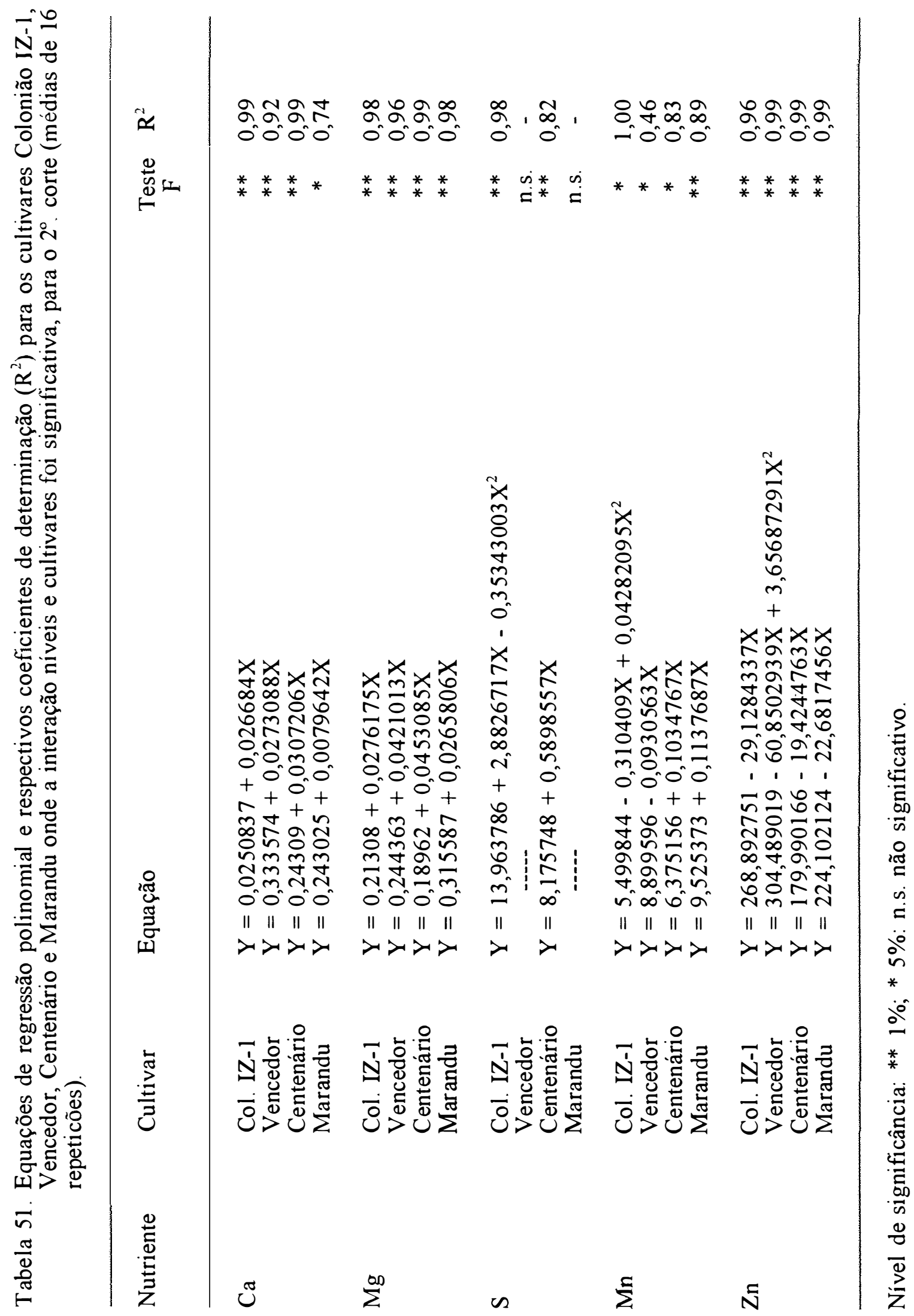




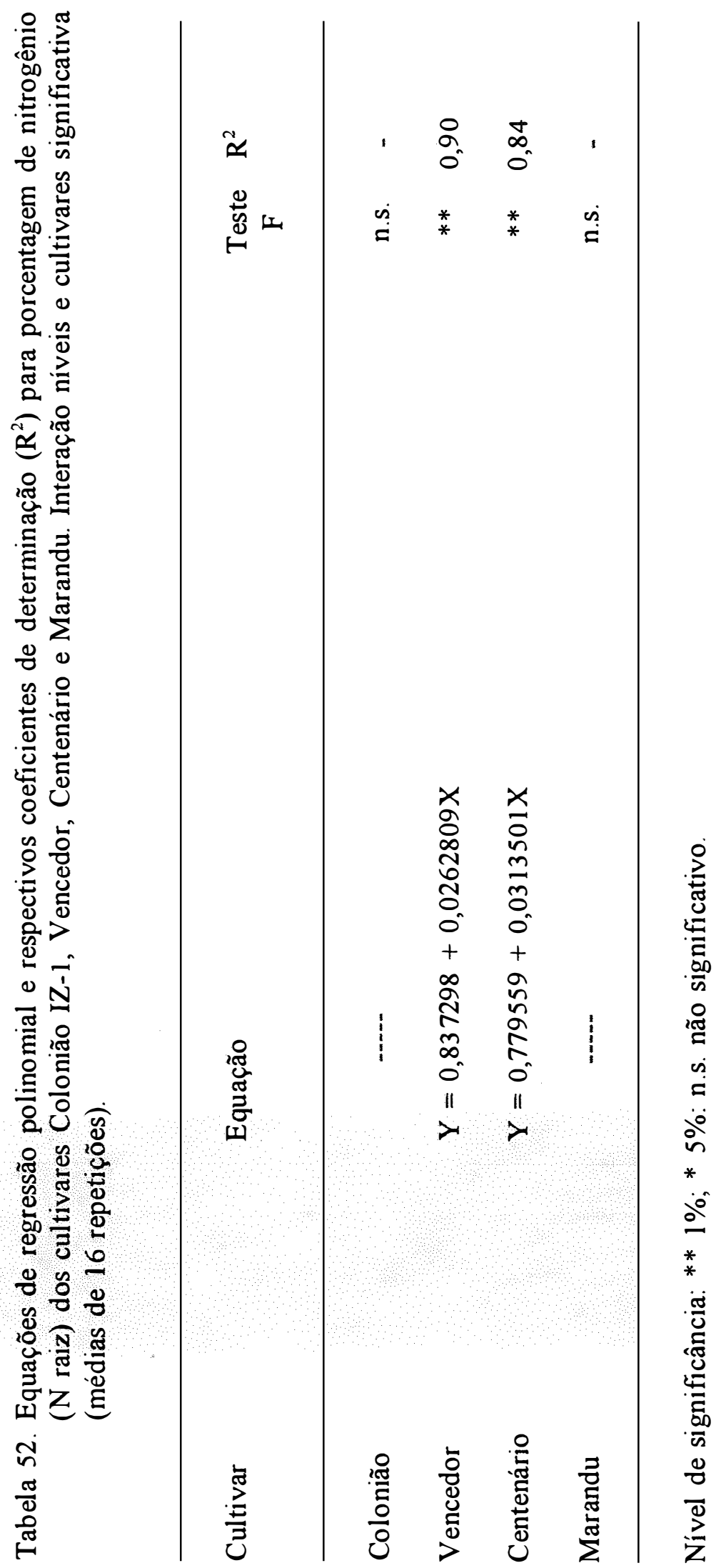

